Zentrum

für Biodiversität und Nachhaltige Landnutzung

Sektion

Biodiversität, Ökologie und Naturschutz

-Centre of Biodiversity and Sustainable Land Use-

Section: Biodiversity, Ecology and Nature Conservation

\title{
Late Quaternary Vegetation and Climate Dynamics in Western Amazonia
}

\author{
Dissertation \\ For the award of the degree \\ “Doctor of Philosophy” (Ph.D. Division of Mathematics and Natural Sciences) \\ Of the Georg-August-University of Göttingen
}

Within the doctoral program Biodiversity, Ecology and Evolution

Submitted by

Paula A. Rodríguez-Zorro

From Sogamoso (Colombia)

Göttingen, 2017 


\section{Thesis committee}

Prof. Dr. Hermann Behling

(Department of Palynology and Climate Dynamics / A.-v.-H. Institute for Plant Sciences)

Prof. Dr. Erwin Bergmeier

(Department of Vegetation and Phytodiversity Analysis/ A.-v.-H. Institute for Plant Sciences)

Prof. Dr. Markus Hauck

(Department of Plant Ecology/ A.-v.-H. Institute for Plant Sciences)

\section{Members of the examination committee}

Prof. Dr. Hermann Behling

(Department of Palynology and Climate Dynamics / A.-v.-H. Institute for Plant Sciences)

Dr. Thomas Giesecke

(Department of Palynology and Climate Dynamics / A.-v.-H. Institute for Plant Sciences)

Prof. Dr. Erwin Bergmeier

(Department of Vegetation and Phytodiversity Analysis/ A.-v.-H. Institute for Plant Sciences)

Prof. Dr. Markus Hauck

(Department of Plant Ecology/ A.-v.-H. Institute for Plant Sciences)

Prof. Dr. Holger Kreft

(Free floater research group-Biodiversity, Macroecology \& Biogeography)

Prof.Dr. Alexander Schmidt

(Department of Geobiology/Evolution of Landplants \& Development of Terrestrial Ecosystems)

Date of oral examination: 15.03.2017 


\section{Para mi familia}





\section{Table of contents}

Preface

Acknowledgements................................................................................................... 11

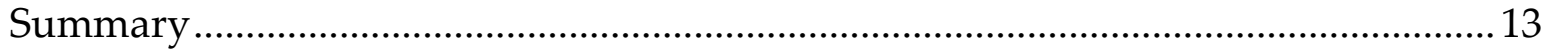

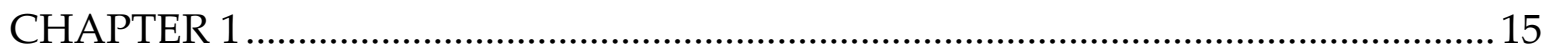

General Introduction........................................................................................... 15

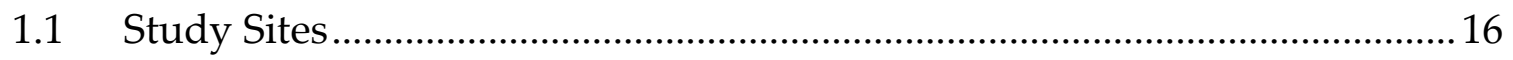

1.2 Geology of the Amazon basin .....................................................................17

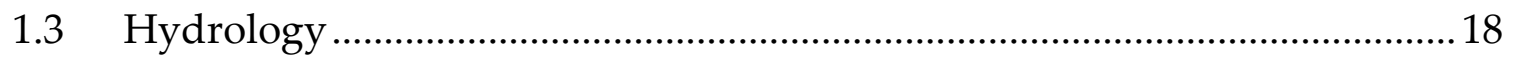

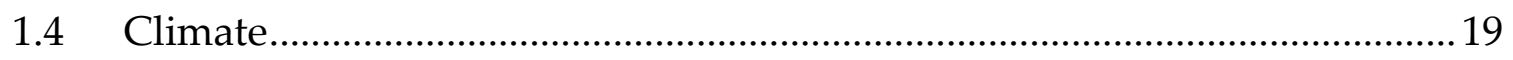

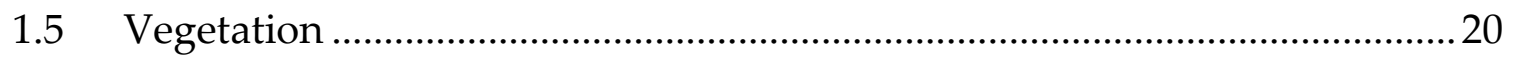

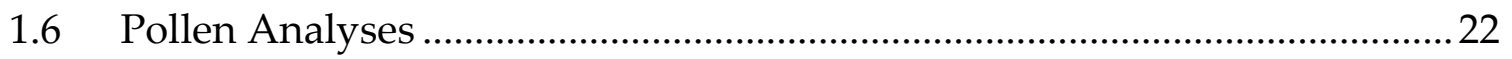

1.6.1 Preparation of pollen samples .............................................................23

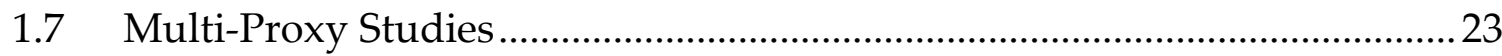

1.8 Late Quaternary Palaeoecology in Western Amazonia .................................24

1.8.1 The Early Holocene …………………….................................................... 24

1.8.2 The Mid-Holocene ......................................................................................... 25

1.8.3 The late Holocene ……….........................................................................25

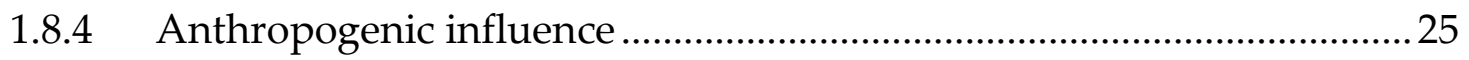

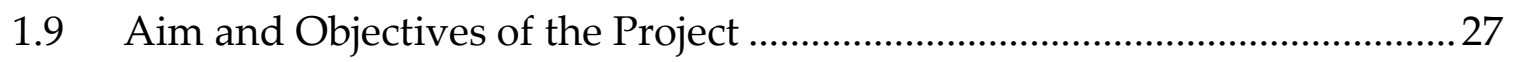

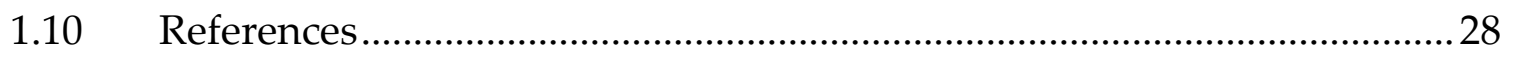

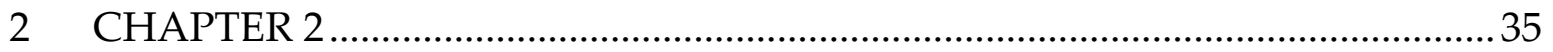

Vegetation changes and human impact inferred from an oxbow lake in southwestern Amazonia, Brazil since the 19th century.............................................35

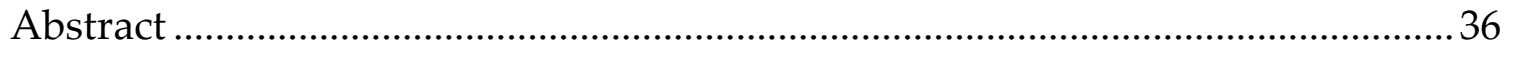

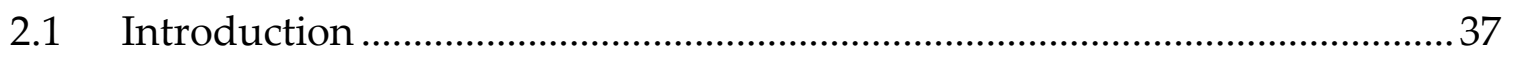

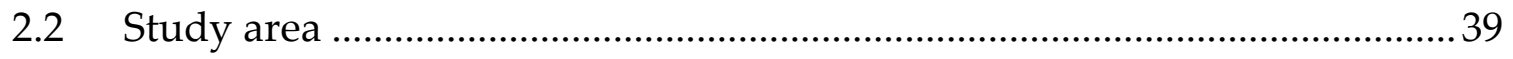




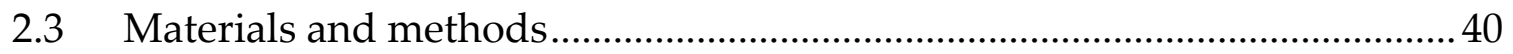

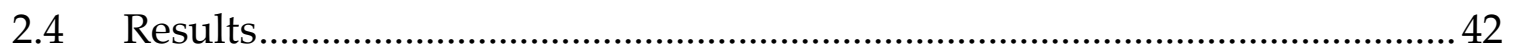

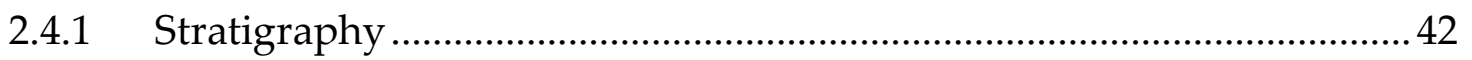

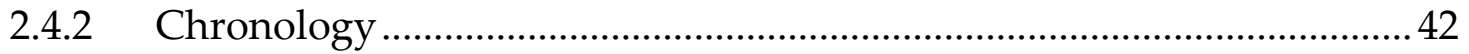

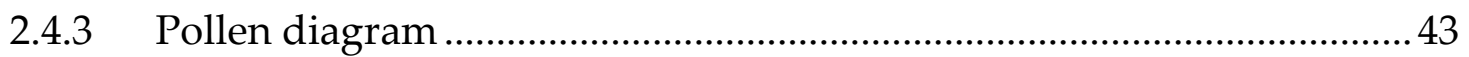

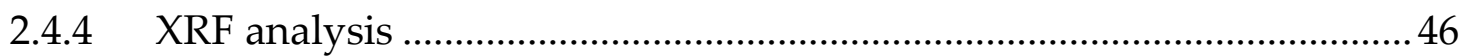

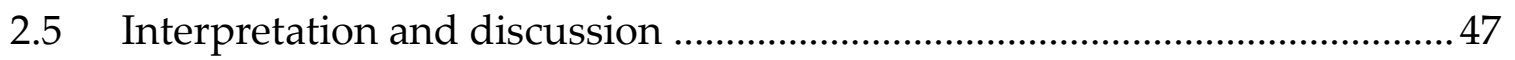

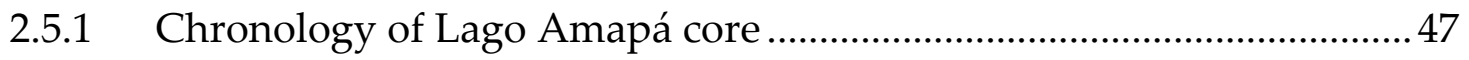

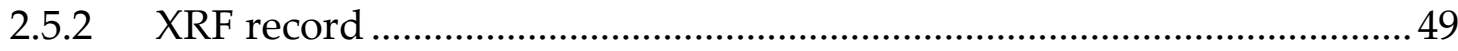

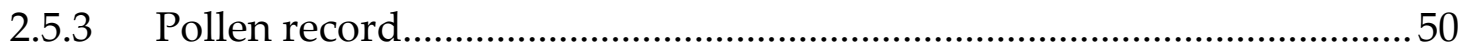

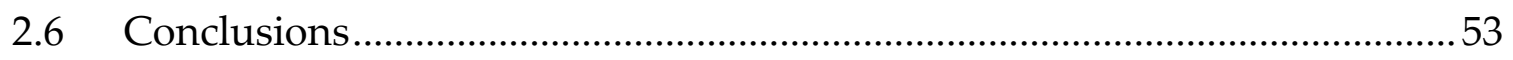

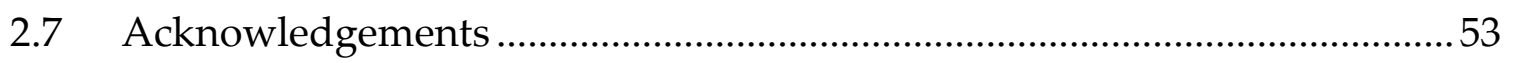

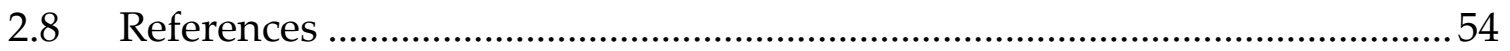

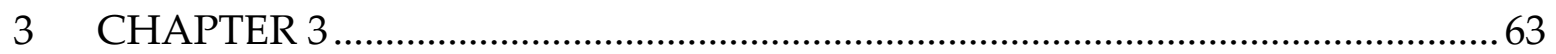

Mid-Holocene vegetation dynamics with an early expansion of Mauritia flexuosa palm trees inferred from the Serra do Tepequém in the savannas of Roraima State in Amazonia, northwestern Brazil. .................................................63

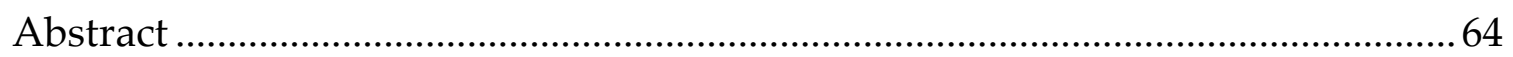

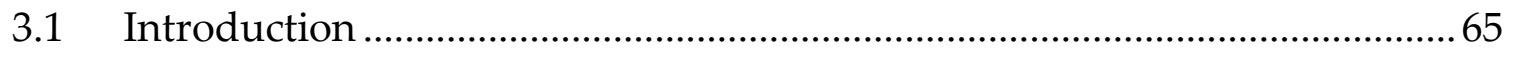

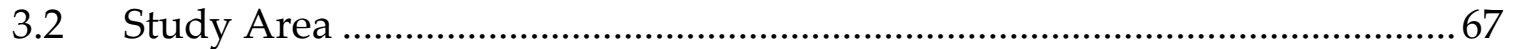

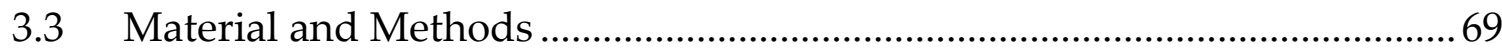

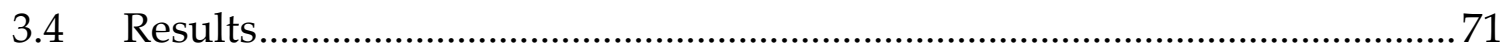

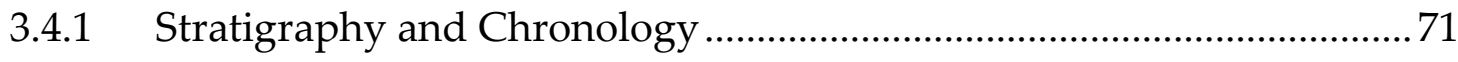

3.5 Description of the pollen diagram ..................................................................

3.5.1 Pollen zone 1 T1 $(200-100 \mathrm{~cm}$; 20 samples $)$............................................. 75

3.6 Interpretation and Discussion .................................................................... 78

3.6.1 Chronology of the sediment core Serra do Tepequém ……………........78

3.6.2 The mid-Holocene at Serra do Tepequém ………………………............79 
3.6.3 A possible human impact during the mid-Holocene ............................... 82

3.6.4 The mid-Holocene at Roraima savannas in Brazil..................................83

3.6.5 A regional overview of the mid-Holocene vegetation changes in

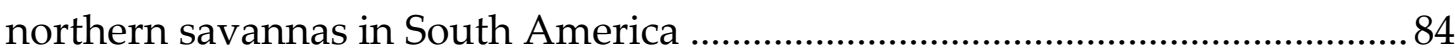

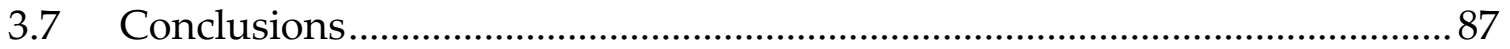

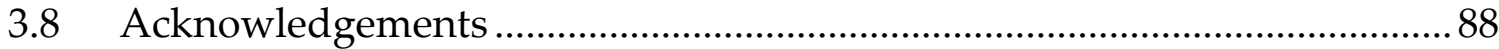

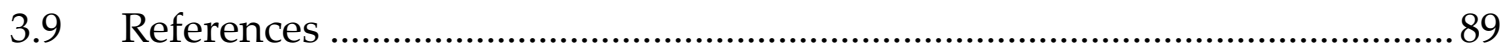

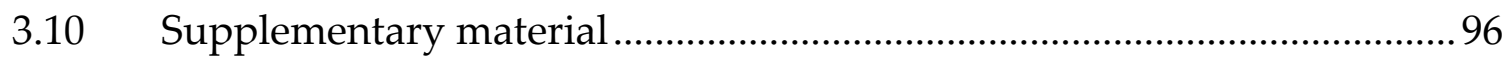

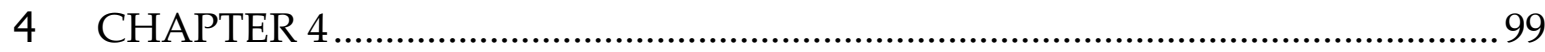

Early and late Holocene Vegetation Dynamics in the Rio Negro Amazon Region and Resilience of Rainforest to Climate Change and River Dynamics ..................99

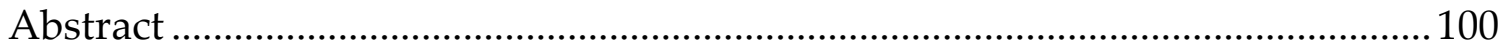

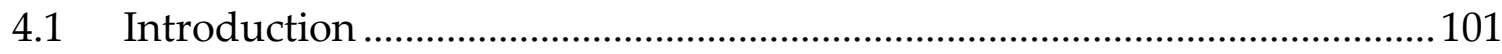

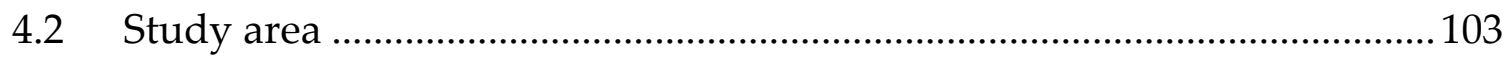

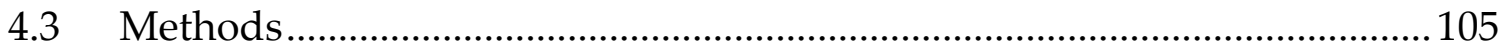

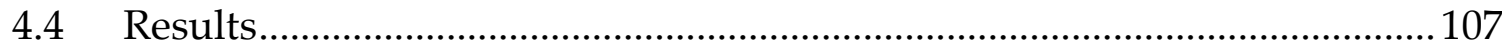

4.4.1 Stratigraphy and chronology ……....................................................... 107

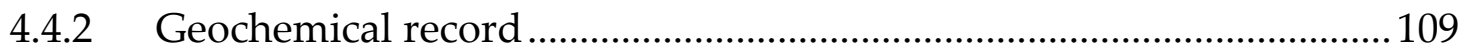

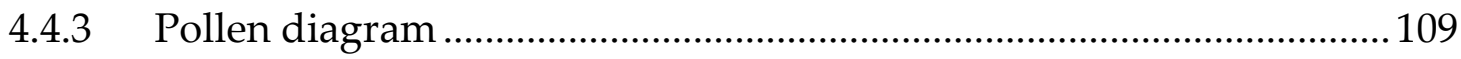

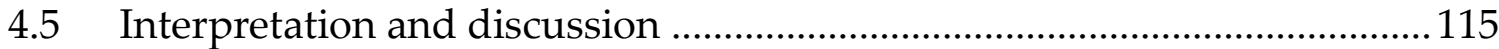

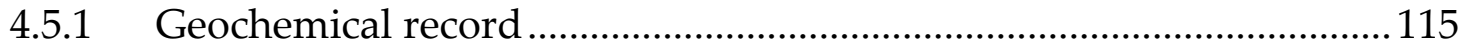

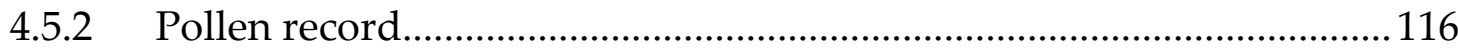

4.5.3 Climate and Regional Vegetation Changes .............................................121

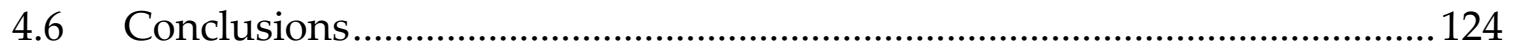

4.7 Acknowledgments ..................................................................................... 124

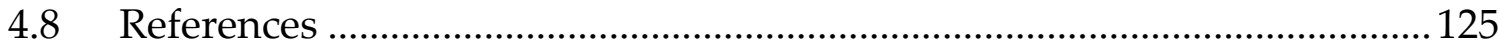

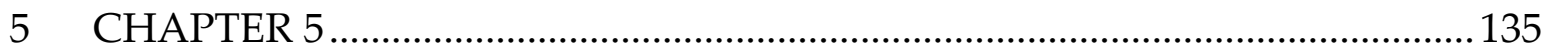

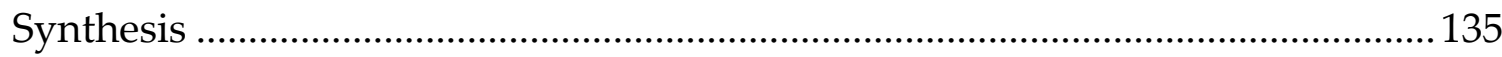


5.1 The floodplain lake records ...................................................................136

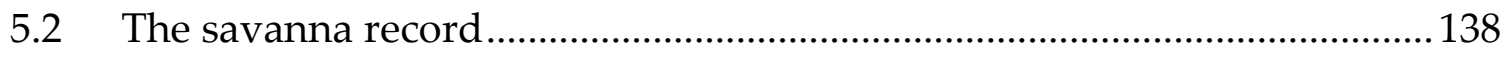

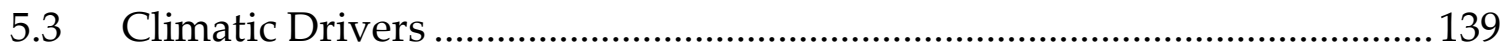

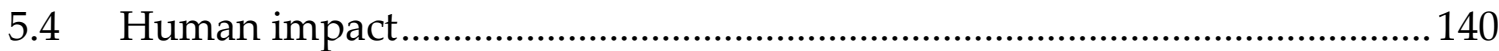

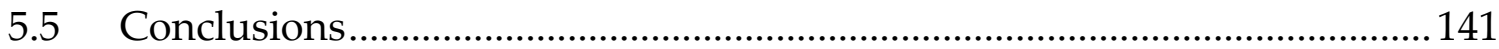

5.6 Remained open questions and outlook …………….................................142

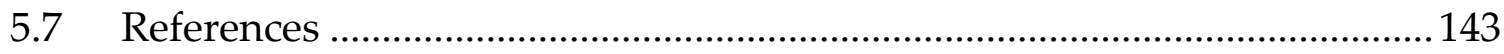

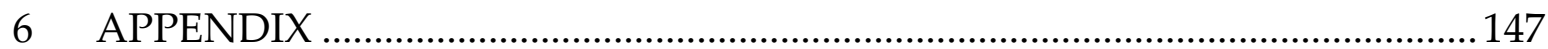

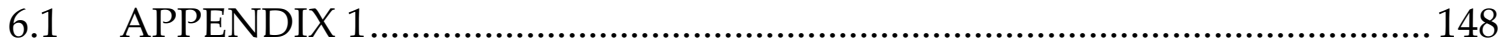

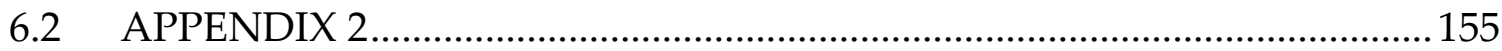

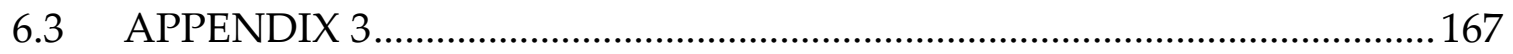




\section{Preface}

This $\mathrm{PhD}$ thesis has been conducted during the period of November 2013 to February 2017 at the Department of Palynology and Climate Dynamics of the University of Göttingen, Germany. The thesis is presented as a cumulative work where a general introduction is followed by three papers submitted to peerreviewed journals. All manuscripts and the content of this thesis were written and led by myself. The formatting for references of the papers follows the specific guidelines of each journal and therefore they differ between chapters. Each research chapter (Chapters 2 to 4 ) has some data that was collected by collaborative authors. All authors are listed at the beginning of each chapter and their contribution is set out in detail below.

Chapter 2. Rodríguez-Zorro, P.A., Enters, D., Hermanowski, B., Costa, M.L., Behling, H., 2015. Vegetation changes and human impact inferred from an oxbow lake in southwestern Amazonia, Brazil since the 19 $9^{\text {th }}$ century. Journal of South American Earth Sciences 62: 186-194. Barbara Hermanowski (Georg-August University of Göttingen, Germany), Marcondes Lima da Costa (Federal University of Pará, Brazil) and Hermann Behling (Georg-August University of Göttingen, Germany) have done the field work and collected the sediment core. Dirk Enters has provided the X-ray fluorescence spectrometry analyses, at the University of Bremen, Germany and was crucial for the interpretation and discussion of the data.

Chapter 3. Rodríguez-Zorro, P.A., ., Costa, M.L., Behling,H., (Accepted) Mid-Holocene vegetation dynamics with an early expansion of Mauritia flexuosa palm trees inferred from the Serra do Tepequém in the savannas of Roraima State in Amazonia, northwestern Brazil. Journal of Vegetation History and Archaeobotany. Hermann Behling and Marcondes Lima da Costa have done the field work and collected the sediment core.

Chapter 4. Rodríguez-Zorro, P.A.,Turcq, B., Cordeiro, R.C., Moreira, L.S., Costa, R.L., Bernardes, M.C., Filho, A., Behling, H., (submitted). Early and late Holocene vegetation dynamics in the Rio Negro Amazon region and resilience of 
rainforest to climate change and river dynamics. Journal of Quaternary Research. The research of this chapter is based on the field survey led by Bruno Turcq (IRD-LOCEAN, Paris, France; Cayetano Heredia University, Perú) and Renato Cordeiro (Federal Fluminense University, Brazil) in the lowlands of Rio Negro. They have facilitated the soil samples for pollen analyses. Bruno Turcq and Luciane Moreira (Federal Fluminense University, Brazil) were crucial for the interpretation and discussion of the geochemical data.

The chapter 5 presents a synthesis that summarizes and discusses the main results of the manuscripts. 


\section{Acknowledgements}

During the time that I have been developing this Ph.D project, many people encouraged and helped me in one way or another.

Firstly, I am very thankful with my first supervisor, Hermann Behling, for giving me the opportunity to be part of his research team and even more for challenging me with this marvelous project in the complex and still unknown Amazon Region. I am also grateful to Thomas Giesecke and Sonia Fontana, for their constant support and stimulating discussions, which encouraged me to explore many aspects of palaeoecology and pollen analyses. I am also thankful for their friendship.

I would like to thank the DAAD-Colfuturo scholarship for the financial support provided during these three years and also to the Department of Palynology and Climate Dynamics for providing a partial scholarship to accomplish the final stage of my studies.

I am also thankful to all my colleagues of the Department of Palynology and Climate Dynamics, which contributed directly or indirectly to my research during this time. I spent a very nice time during scientific and social meetings with you. I would like to thank Jörg Christiansen for his patience and help with technical and burocratic issues. Special thanks to Anggi Hapsari, who was always there for scientific and personal advices; thank you for your friendship. I am also very thankful to Carolina, Lyudmila, Ricardo and Vincent for sharing scientific and cultural thoughts accompanied by German beer. Many thanks to my office mate, Fang, who was always taking care of me.

I would like to thank all my friends outside the scientific life, which were an immense support. Big thanks to Franziska Barth and Annika Landau who were always very supportive with me. Laura Malagón and Martha León are thanked for their wise advices and nice transcendental talks. Big thanks to my roommate Anni Hoff who was very helpful with the English revision of this thesis. 
Special thanks to my family in Germany, Nayibe and Peter Giefers, who were sharing with me the German culture and were also an enormous support. I am grateful to Veronica for sharing her photography passion with me, besides the nice time spent in our beloved Berlin.

Lastly, I would like to thank my family in Colombia- my parents Ana and Raúl, my sister Camila, José, Leonor, Lorenzo and Vivian. Without their encouragement and support I would not be where I am now. I am very grateful with my partner Claudia who was very patient and helpful, making my life colorful and happy during this time. 


\section{Summary}

The Amazon is a shelter for a huge variety of fauna and flora with the largest fluvial system and the highest diversity in the world. The biotic and abiotic factors of the floodplains serve to control the development and evolution of the ecosystems of the region. In the Amazon lowlands, little is known about past vegetation and ecosystem dynamics and to an even lesser extent human disturbances. Therefore, this project presents three palaeoecological multi-proxy studies from the western part of the Amazon region in Brazil. The aim is to reconstruct the vegetation and climate changes as well as possible human impact during the late Quaternary.

A palaeoecological record from the floodplain areas of the Acre River, southwestern Brazil revealed the development and vegetation dynamics of a young oxbow lake (Lago Amapá) since the $19^{\text {th }}$ century. The Lago Amapá record showed two main periods of changes. First the lake was influenced by fluvial input and afterwards the lake had a complete lacustrine phase. From ca. 1900 AD (Anno Domini) the main factors of transformation in vegetation were the fluvial dynamics, reflected by the input of sediments and pollen, transported by the river originating from Peruvian headwaters. From ca. 1950 AD the lake was rather isolated and only filled up when exceptional severe flood events occurred. Due to its close proximity to the City of Rio Branco at this time, it is assumed that the vegetation dynamics were altered by human activities. The increase of pioneer taxa, changes in sediment source and a comparison from Landsat images from the last 30 years, which showed a vast transformation in the vegetation cover close to the lake, displayed an extensive human impact.

Towards the northwestern part of the Amazon region, a mid-Holocene record from a uniquely isolated plateau, the Serra do Tepequém, reflected a regional change from dry to wetter conditions, and an early expansion of the Mauritia flexuosa palm. A dry period was detected by the presence of grassland taxa, creeping pteridophytes and a high regional signal of fires between the period 7570 to 6190 cal BP (calibrated years Before Present). Subsequently, a wetter environment was detected by the changes in forest composition, reduction of 
grasslands and an increase on Mauritia flexuosa palm from 6190 to $4900 \mathrm{cal}$ BP. In addition, the study showed that the early increase in $M$. flexuosa developed differently to the increase in fire and savanna expansion found in the savanna region in Venezuela

The third study, a multi-proxy record from the remote region of the middle-upper Rio Negro showed the role of climate and river dynamics on the vegetation assemblages during the early and late Holocene. The Lake Acarabixi sediment core revealed that the forest was resilient to changes in the amount of precipitation and the filling dynamics of the valley of Rio Negro, which ended around $8000 \mathrm{cal} \mathrm{BP}$ in the Lake Acarabixi. In the early Holocene (10,840 to $8240 \mathrm{cal} \mathrm{BP})$, herbs and open forest occurred, reflecting reduced precipitation with a seasonal climate. After 8240 to $1600 \mathrm{cal} \mathrm{BP}$ a large hiatus in sedimentation occurred. In the late Holocene (1600 to $650 \mathrm{cal} \mathrm{BP}$ ) the lake reflected more lacustrine phases, and forest were closed with more flooding tolerant species. 


\section{CHAPTER 1}

\section{General Introduction}

The Amazon basin is the largest fluvial region in the world, covering an area of about 5.5 million $\mathrm{km}^{2}$ (Irion and Kalliola, 2010). It consists of 815 million ha with different types of vegetation such as rainforest, transitional forest, and savannas holding around 16,000 tree species (Ter Steege et al., 2013). In addition, it is home to approximately 427 mammals, 1294 birds, 378 reptiles, 427 amphibians and 3000 fish, making it the most diverse region of the world (Silva et al., 2005; Lundberg et al., 2010).

Nowadays, the Amazon is subject to several disturbances due to climatic and human influence (e.g. Almeida-Filho and Shimabukuro, 2002; Fearnside, 2006; Lewis et al., 2011; Roosvelt, 2013; Rodríguez-Zorro et al., 2015). The recent occurrence of extreme droughts, due to climatic anomalies, initially reflects the future scenario of drought in the Amazon (Lewis et al., 2011 and literature cited therein). The fluvial systems would decrease in their water levels and forests would be more vulnerable to fire. Additionally, the human activities that involve eradication of the forests, may reduce forest evapotranspiration and therefore the water cycle will be altered (Spracklen et al., 2012; Aragão, 2012). 
In this regard, palaeoecology can be used as a tool to reconstruct long ecological changes in order to detect the response of organisms to environmental changes in the past, including human activities (Birks, 2012). Furthermore, it can provide a background to develop future conservation strategies and predict future climatic scenarios (Willis, 2007).

This project was developed in order to contribute to the understanding of the different past dynamics that have influenced the ecosystems in the western Amazon region in Brazil. Three sediment records from different locations in the Amazon biome in Brazil were used to evaluate the effect of the fluvial dynamics, climate and possible human disturbances on the vegetation arrangements during the late Quaternary.

\section{Study Sites}

The three sediment cores were retrieved from different locations of the western part of the Amazon biome (Figure 1).
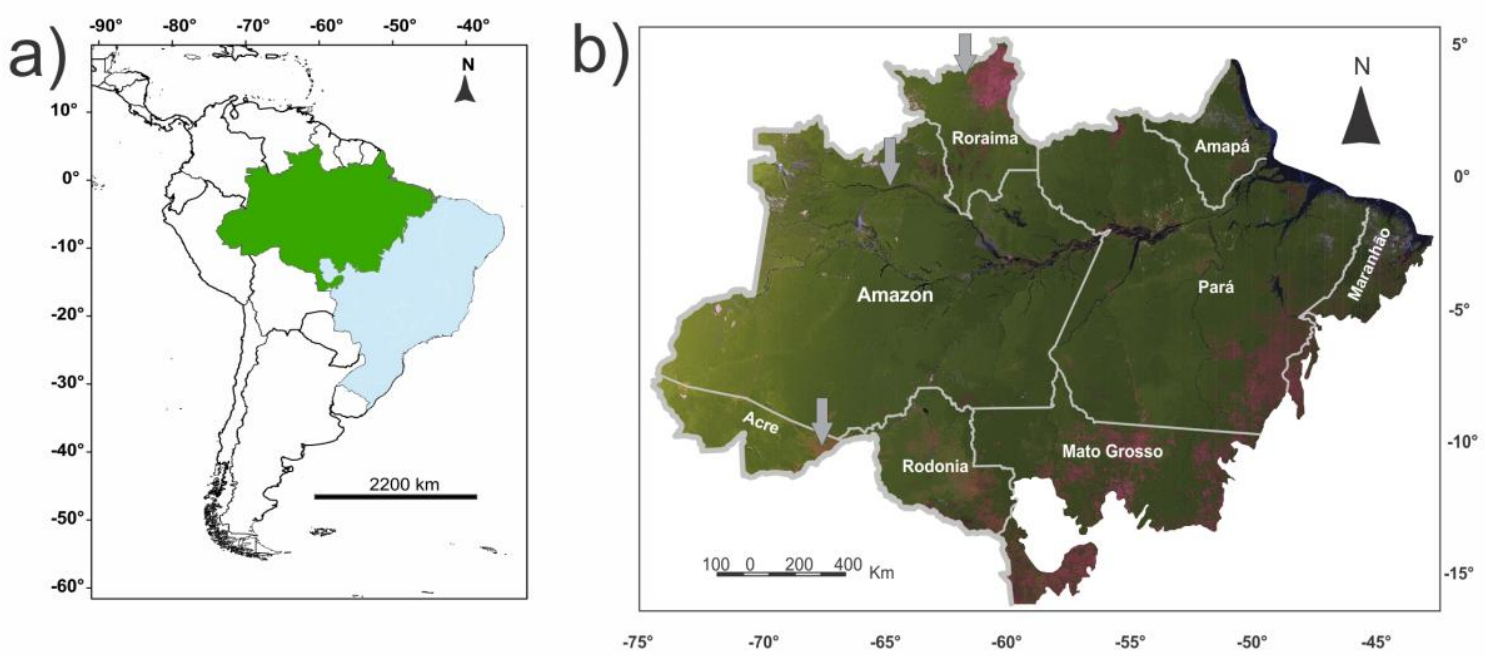

Figure 1. The Brazilian Amazon biome. a) Map of South America highlighting the Brazilian Amazon biome in green. b) Amazon biome in Brazil (data courtesy of the Ministerio do Meio Ambiente in Brazil (MMA, 2006). The grey arrows represent the study site locations.

The first study site, Lago Amapá, is located towards the South West in the surroundings of the Rio Branco city in Acre state. The sediment core was retrieved in an oxbow lake of the Acre River. The second study site is located at the North 
West of the Amazon basin, in an isolated Plateau, the Serra do Tepequém in the Roraima state. The sediment core was collected from an exposed wall in a spring area of the plateau (635 m elevation). The last study site, Lake Acarabixi, is located in the floodplain areas of the middle-upper part of the Rio Negro. The sediments were collected from a floodplain lake of the Rio Negro valley.

\section{Geology of the Amazon basin}

The Amazon Craton has been the main base and source of sediments input for the fluvial systems through almost all the geological history of South America (Hoorn

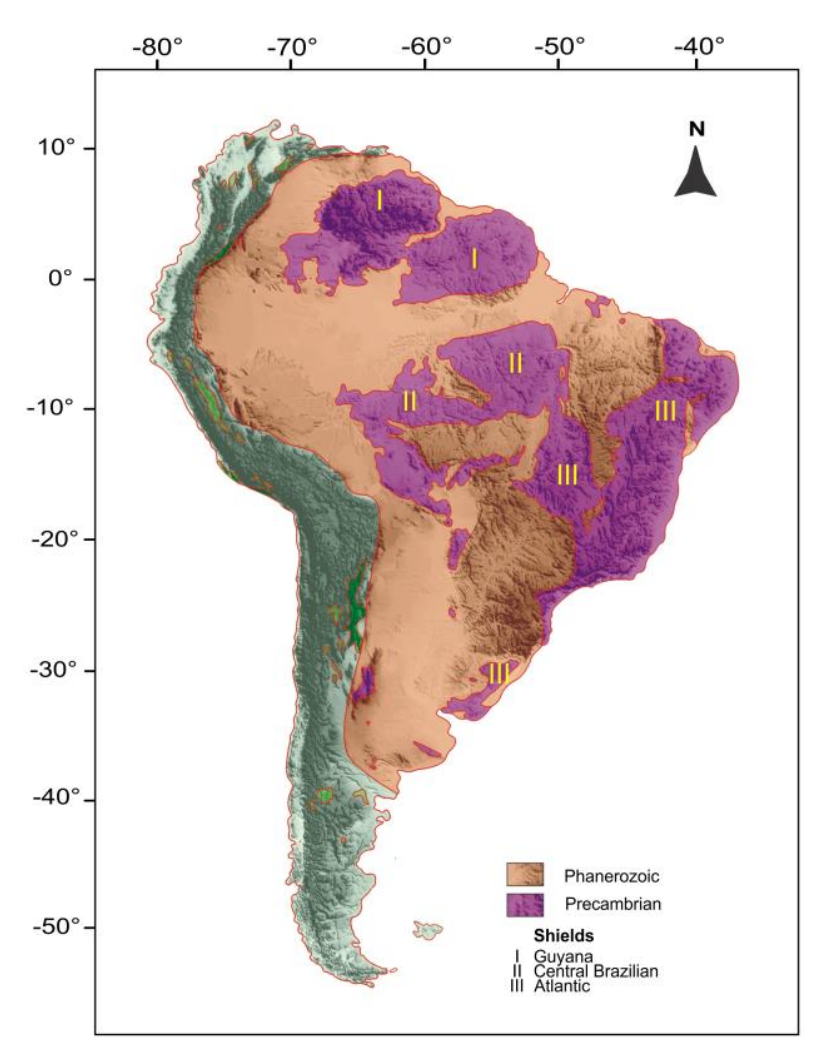

Figure 2. Continental area of the South American plate. (Adapted from the Geologia, tectônica e recursos minerais do Brasil-Brazilian Geological service (CPRM), 2003). et al., 2010a,b). During the late Ordovician, the Amazon Craton was divided into the Central Brazilian Shield (south) and the Guyana Shield (north), which were the responsible of the origin of the Solimões and Amazonas Paleozoic sedimentary basins (Hoorn et al., 2010a; Wanderley-Filho et al., 2010) (Figure 2). After the Paleozoic, the basin evolved mainly as a result of plate tectonic dynamics (WanderleyFilho et al., 2010). Following a continental break up (135 to $100 \mathrm{Ma}$ (Million years BP)), both, the growing Atlantic Ocean and plate tectonic adjustments along the Pacific margin, caused deformation within the Amazon Craton, and later on the formation of the Andes

(Hoorn et al., 2010b). Around 73 million years BP the rivers drained to the west into a depression along the eastern border of the Early Andes that opened to the Caribbean Sea (Junk and Piedade, 2010). Large freshwater lakes were formed during the Paleogene and early Neogene period such as the Lago Pozo and the Lago Pebas. Those lakes were filled with sediments of riverine origin from the 
Andes and the shields of Central Brazil and the Guianas (Junk and Piedade, 2010). Later, as a consequence of the changes from Cratonic to Andean dominated landscapes, the drainage systems were inverted eastwards, away from the Pacific Ocean and the Caribbean Sea, creating the modern Solimões and Amazon river systems (Wanderley-Filho et al., 2010; Hoorn et al., 2010a) (Figure 3).

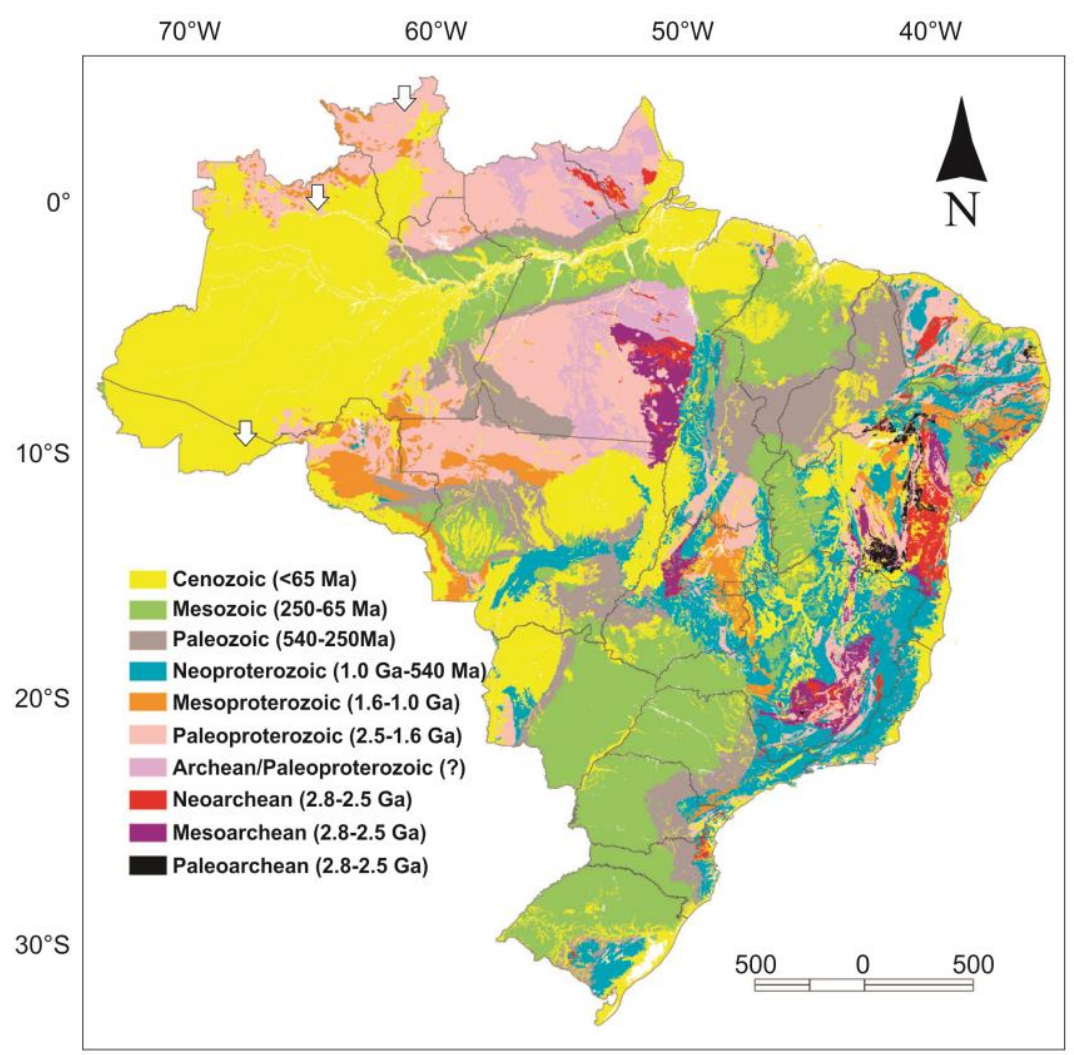

Figure 3. Geological eras of Brazil. White arrows represent the study sites. (Map adapted from the Geologia, tectônica e recursos minerais do Brasil-Brazilian Geological service (CPRM), 2003).

\section{Hydrology}

The floodplain along the Amazon main stem in Brazil ( 2,800 km length), spreads over approximately $92,400 \mathrm{~km}^{2}$ (Latrubesse, 2012). The quaternary Amazon basin is drained by a huge network of tributaries, which depending on the geological origin can be classified as white, black and clear water rivers (Figure 4). The white water Rivers, which origin in the Andes, are characteristic for their large amounts of nutrient rich-sediments that they transport (Junk and Piedade, 2010). These sediments are the result of the high erosion rates due to the ongoing uplift of the 
Andean Cordilleras. Coarse sediments are deposited at the foothills and finer ones are transported as suspended load across the continent, to the Atlantic Ocean (Irion and Kalliola, 2010). Examples of rivers that have their head waters in the Andes are the main Amazon steams, the Purus, Jaruá and Madeira. Contrary, the following two river types are Cratonic Rivers, where the main bed load that they carry in their sediments is composed by quartz (Hoorn et al., 2010a and literature cited therein). The black water rivers are carrying large amounts of white sand into the central basin and on the shield (Figure 2 and Figure 4) (Junk and Piedade, 2010). The water of those rivers has high amounts of humic acids

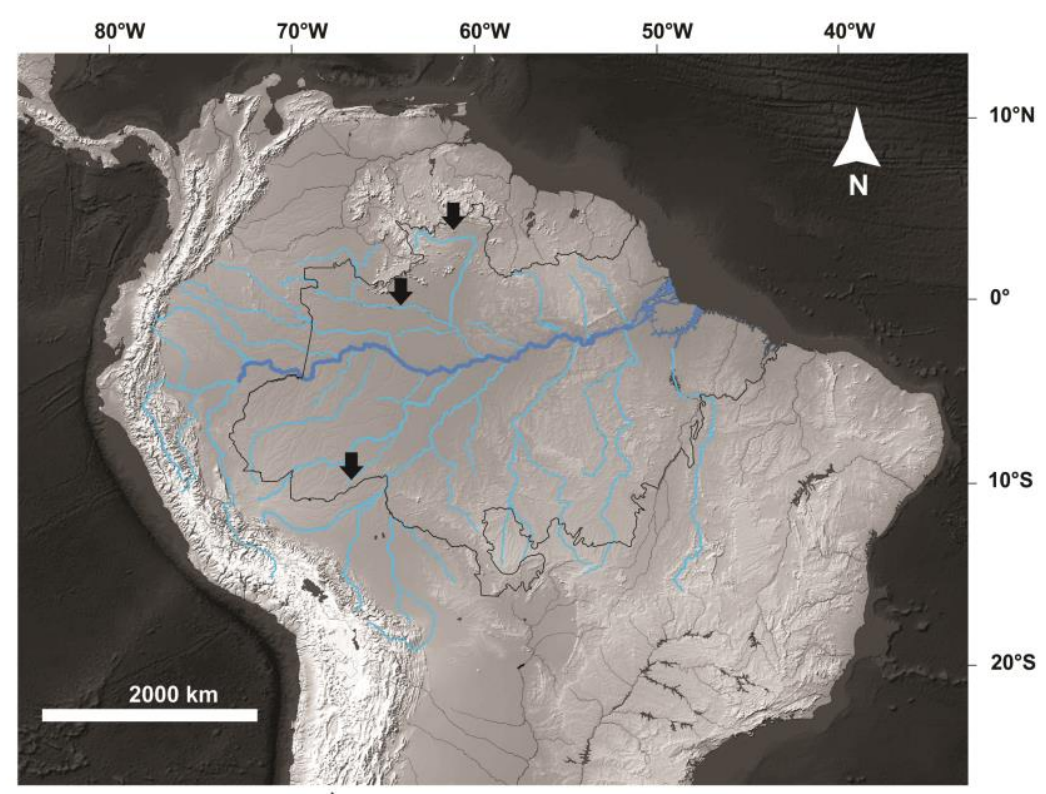
and low amounts of suspended matter (Junk and Piedade, 2010). An example of such a river type is the Rio Negro,

Figure 4. Hydrology of the Amazon region. Dark blue line shows the main steam of the Amazon River. Light blue lines represent the most important tributaries of the Amazon River. Black arrows show the study sites location.

which is the largest black water river of the basin and of the world. The third type of rivers, clear water rivers, like the Tapajós, Xingu, and Tocantins, has their catchments in archaic shields of Guiana and Central Brazil. Those rivers are high in $\mathrm{pH}$ values and blue to green in color.

\section{Climate}

The changes in precipitation in the Amazon are the result of different regional processes, which are regulated by large-scale circulation and local water sources from forests and soil moisture (Drumond et al., 2014). The high evapotranspiration rates produced by the Amazon rainforest are very important for the water cycle in the basin and as well as for the regional and global climate (Nobre et al., 2009; 
Wang et al., 2017). The main driver of the seasonality, intensity and spatial distribution of precipitation in the Amazon is the seasonal migration of the Inter Tropical Convergence Zone (ITCZ) (McGee et al., 2014) (Figure 5). Moreover, the factors that trigger the displacement of the ITCZ over the tropical North Atlantic are anomalous warm Sea Surface Temperatures (SST). A migration of this kind transports heat from the warm hemisphere into the cold hemisphere via Hadley

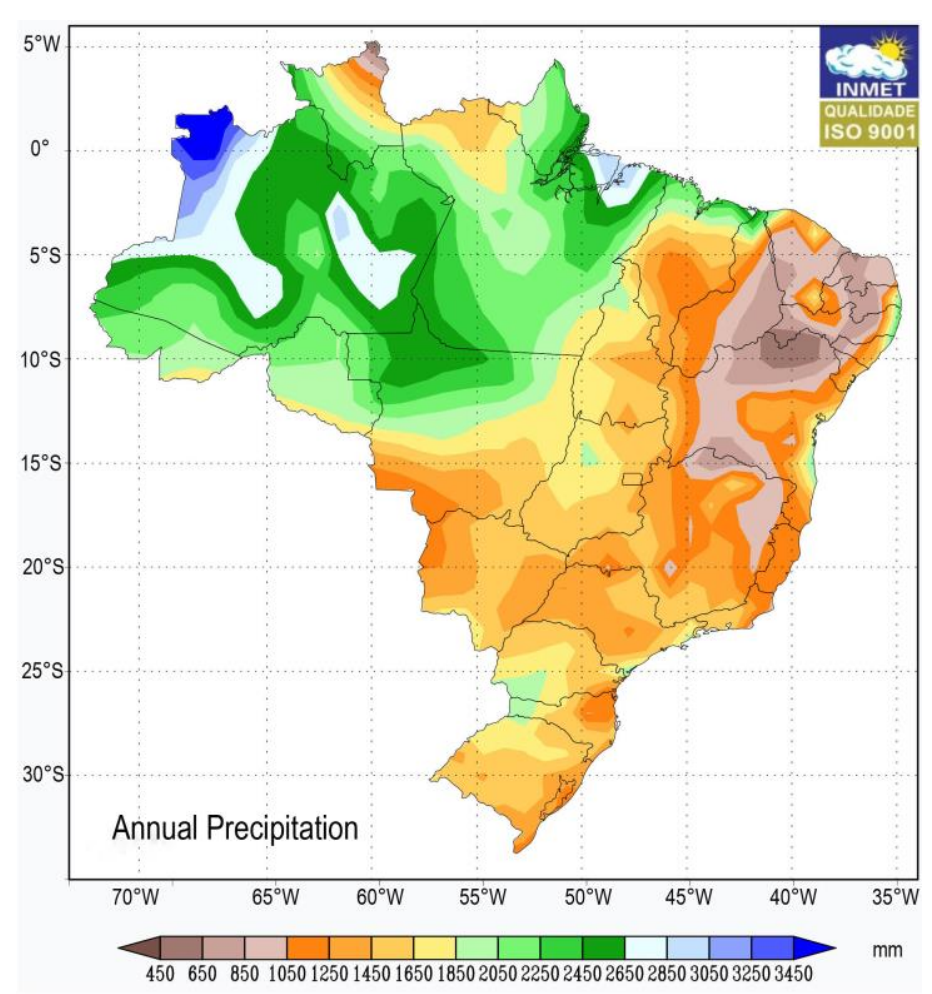

Figure 5. Annual precipitation in Brazil. Adapted from the National Institute for Space Research in Brazil (INPE, 2017) circulation (McGee et al., 2014). Consequently, the climatological annual cycle of precipitation is not homogeneous over the Amazon, and the start and end of the rainy season varies gradually from the southern basin up northwards (Drumond et al., 2014 and literature cited therein) (Figure 5). In the southern part of the basin, the rainy season occurs between austral spring and autumn, while over the western and the northern Amazon it extends from austral autumn to spring (Drumond et al., 2014).

\section{Vegetation}

The Amazon biome spreads over eight countries with an area of $6700 \mathrm{~km}^{2}, 69 \%$ of it being part of Brazil (Ferreira et al., 2005) (Figure 1). It contains a huge range of vegetation types that are very characteristic depending on the biotic and abiotic factors that shape such landscapes.

The vegetation in the Acre state, where the Lago Amapá oxbow lake is located, can be classified as open alluvial rainforest with some patches of dense lowland tropical rainforest (MMA, 2006; Lani et al., 2008; IBGE, 2012). Such vegetation can be found along the water courses and grows over plains and terraces that are 
periodically flooded (Figure 6). The area is characteristic to have a very high amount of palms trees from the genus Astrocaryum, Iriartea, Attalea, Euterpe, Mauritia and Socratea (Lani et al., 2008). Among the arboreal vegetation, species belonging to the families of Lecythidaceae, Meliaceae, Euphorbiaceae, Bignoniaceae, Apocynaceae, Moraceae, Fabaceae and Rutaceae can be found (Lani et al., 2008).

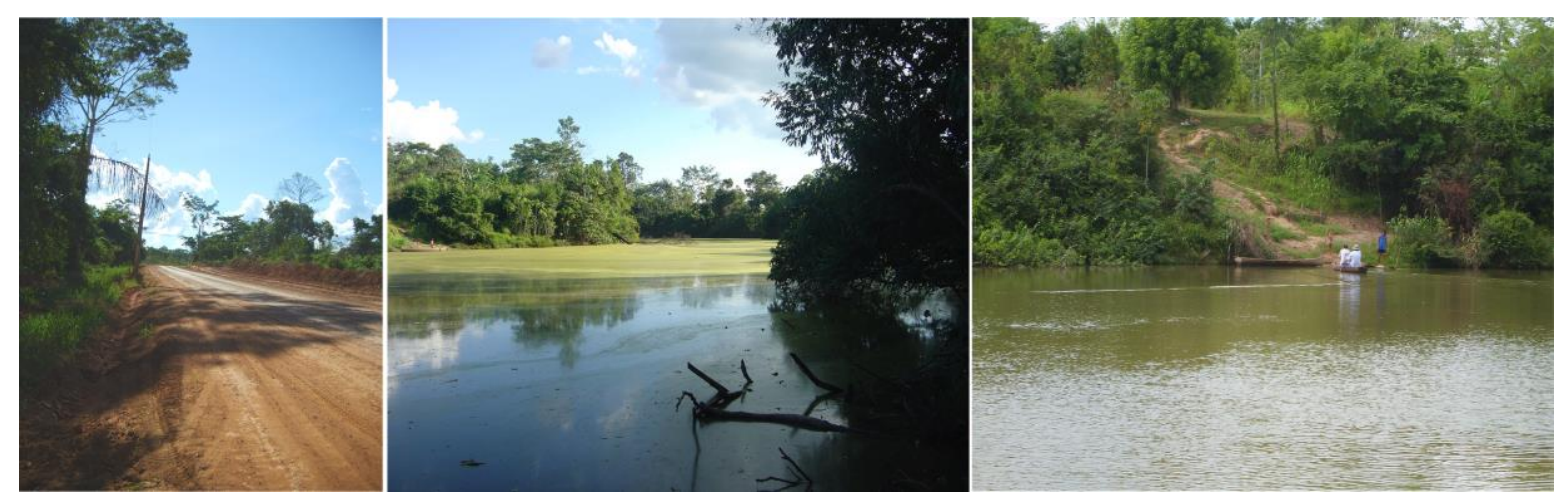

Figure 6. Lago Amapá. Road behind the lake (Right). Vegetation on the shores of the lake (middle and left). Photos by B. Hermanowski.

Different from the lowlands in the Acre state, the vegetation of Serra do Tepequém occurs on an isolated plateau, which is mainly composed of grasses from the genus Andropogon, Trachypogon apart from some Cyperaceae (Barbosa and Miranda, 2004) (Figure 7). The Plateau displays some shrubs and grasses that can be found in open grass savannas on the plains as well as in arboreal savannas of the valleys (Nascimento et al. 2012; Beserra Neta et al. 2015). Trees from the genus Aspidosperma, Tabebuia, Mimosa, Piptadenia, Cassia are usually growing in the area. Small patches of the Mauritia flexuosa palm are found in some areas of the plateau (Barbosa and Miranda, 2004).

At last, the Rio Negro valley has characteristic vegetation, the igapó forests, which is adapted to geological and hydrological processes in the area. As explained by Junk and Piedade (2010), the flora of the igapós is closely related to the woodlands of oligotrophic campinas and caatingas and those of white-sand savannas. These areas show periodically high groundwater levels or even shallow flooding and thus require the respective adaptations of the trees (Junk and Piedade, 2010). 

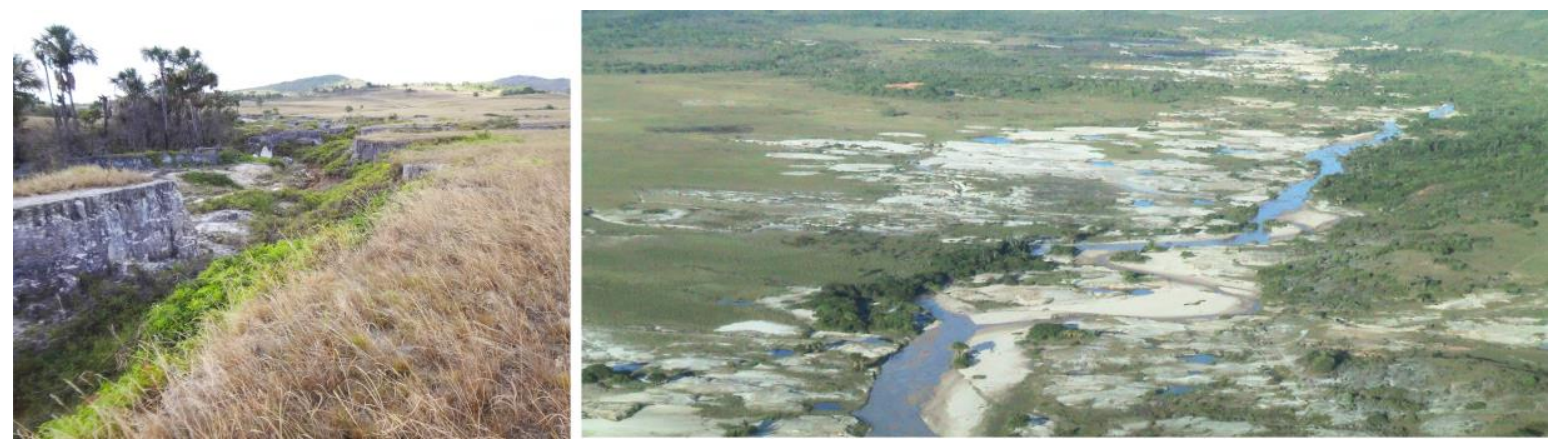

Figure 7. Serra do Tepequém. Vegetation growing in the surroundigs of the coring side (right). Human disturbances along the plateau (left). Photos by H. Behling and M. Costa.

In terms of tree composition, Heterostemon mimosoides, Aldina heterophylla, and Eschweilera atropetiolata are dominant species and particularly restricted to the Negro basin. The Chrysobalanaceae, Lecythidaceae and Euphorbiaceae appear to be particular characteristic families along the Negro River (Montero, 2012; Montero and Latrubesse, 2013).

\section{Pollen Analyses}

Pollen analyses have proven to be a very useful tool to reconstruct past vegetation dynamics, since pollen grains are preserved for long periods of time in the sediments and have specific morphological characteristics that can be associated to a vegetation type (Birks and Birks, 1980; Faegri and Iversen, 1989). Pollen grains are formed in the anthers, which are the male part of the flower (Faegri and Iversen, 1989). After the anthers release the pollen grains, part of them will be used for plant fertilization (pollination) by different dispersal mechanisms such as animals (entomphilous) or the wind (anemophilous). The rest of the pollen grains will be dispersed and land on specific surfaces (e.g. lakes, peat bogs, rivers, soils), where they will be deposited (Birks and Birks, 1980). The component that preserves the pollen grains over longer periods of time is the sporopollenin contained in the outer layer of the wall of the pollen grain, which is very resistant to physical, chemical and biological processes (Birks and Birks, 1980). Furthermore, the pollen grains viewed under the microscope, can be associated to specific taxonomic levels, which later could lead to a vegetation reconstruction of certain area (Birks and Birks, 1980). 


\subsubsection{Preparation of pollen samples}

The extraction of the pollen content from the sediment samples is done according to standard processes (Faegri and Iversen, 1989). The procedure that was used for the analyzed study sites is described as follows:

A tablet of Lycopodium clavatum (batch number: $20848 \pm 1546$ ) was added per sample. Afterwards, samples were treated with a solution of $10 \%$ Hydrochloric acid $(\mathrm{HCl})$ to dissolve the exotic marker (Lycopodium clavatum) and carbonates. Later, the samples were sieved through a $150 \mu \mathrm{m}$ mesh and further treated with $70 \%$ Hydrofluoric acid (HF) for 24 hours with the purpose of removing the silicates. The samples of the sediment cores of Lago Amapá and Serra do Tepequém were treated with $70 \%$ HF. For the samples collected from Lake Acarabixi, the $40 \% \mathrm{HF}$ was used and added twice under heat $\left(\mathrm{ca} .90^{\circ} \mathrm{C}\right)$ for 30 minutes. The next step was adding $10 \%$ Potassium Hydroxide $(\mathrm{KOH})$ to the samples, which subsequently were heated $\left(\mathrm{ca} .90^{\circ} \mathrm{C}\right)$ for 5 minutes. This process step was only used on the samples of Lake Acarabixi to remove humic acids and break down organic matter. All the samples were further treated with acid acetic $\left(\mathrm{CH}_{3} \mathrm{COOH}\right)$ to dehydrate the samples, since the acid used for acetolysis is highly reactive to water. Subsequently, the acetolysis solution was added (9:1 mixture of acetic anhydride $\left.\left(\mathrm{CH}_{3} \mathrm{CO}\right)_{2} \mathrm{O}\right)$ and concentrated sulphuric acid $\left(\mathrm{H}_{2} \mathrm{SO}_{4}\right)$ and the samples were heated $\left(\mathrm{ca} .90^{\circ} \mathrm{C}\right)$ for 10 minutes in order to remove the cellulose. At the end, the samples were kept in glycerine gelatine as a medium to prepare the pollen slides for counting.

\section{Multi-Proxy Studies}

The pollen fossil analyses can be linked to other proxies such as Loss on Ignition (LOI), geochemistry, charcoal, with the aim to provide more information on the sediments, past deposition processes and occurring events in the catchment area (Birks and Birks, 1980).

In the Amazon region the lakes are restricted to singular geomorphic features in the uplands and plateaus or can develop as a consequence of fluvial processes in floodplain environments (Latrubesse, 2012). As the sediments from lakes are the sources of past fossilized communities, their analysis can be combined by using multi-proxy techniques. At first, pollen analysis is used to detect past vegetation 
changes that were usually affected by fluvial dynamics in the amazon floodplains. At the same time, using additional proxies, it is possible to detect processes of diagenesis, transportation and redeposition along with the influences of biogeography and evolution of the study sites (Birks and Birks, 1980).

\section{Late Quaternary Palaeoecology in Western Amazonia}

The late Quaternary palaeoecological and archaeological studies reflect that the Amazon region has been subject to different sort of disturbances depending on the geographic location, human activities and climate, which in some periods reflected a regional trend. Most of the records have been taken from transitions zones where the signs of climate and vegetation changes can be easily detected (e.g. Mayle et al., 2002; Hooghiemstra and Berrio, 2007; Rull et al., 2013; Hermanowski et al., 2015). However, in the lowlands, as a result of the highly dynamic fluvial systems, only few records are available for the purpose of having a view into the different climatic and vegetation changes in that region (e.g. Behling et al., 2001; Irion et al., 2006; Bush et al., 2007).

\subsubsection{The Early Holocene}

Recent studies on speleothem records revealed that in the early Holocene, the western part of the Amazon basin was subject to dry phases, which is supported by palaeoecological studies in the region (e.g. Behling and Hooghiemstra, 2000; Cheng et al., 2013). Studies from the savanna ecotones in Colombia and Venezuela reported a dry period showing that savanna vegetation was dominant (Hooghiemstra and Berrio, 2007; Rull et al., 2013). In addition, Bolivian savannas had a dry phase and were dominated by seasonally flooded savannas (Burbridge et al., 2004). In the Ecuadorian lowlands drier climates dominated, but the vegetation was not drastically affected (Weng et al., 2002). In the lowlands of the Rio Negro valley, the records of the Hill of Six Lakes (Bush et al., 2004; D'Apolito et al., 2013) showed that such a dry period did not have a noticeable effect on the forest vegetation assemblages, as also found in the record of Lake Acarabixi (Chapter 4). In fact, a recent study from Wang et al. (2017) showed that dry periods during the last 45,000 years BP were not dry enough for forest to have converted into savannas, indicating that even though there was less recycling of water the forests were resilient to droughts in the lowlands. 


\subsubsection{The Mid-Holocene}

According to speleothem records from the Andes, the mid-Holocene period was characterized by sporadic wet and dry events, but with a dominance of dry climates (Bustamante et al., 2016). Most of the palaeoecological evidence from the western part of the Amazon biome has shown a dry period as well (Mayle et al., 2000; Correa-Metrio et al., 2010; Bush et al., 2016a). However, such a dry period was not observed in records at the north and northwestern part of the biome (Behling and Hooghiemstra, 2000; Hooghiemstra and Berrio, 2007; Rull et al., 2013; (see Chapter 3). In the Amazon rainforest/savanna transition zone of the Llanos Orientales in Colombia, for instance, wetter conditions were registered already at ca. 6500 cal BP (Behling et al., 2001). Furthermore, the record of the Hill of Six lakes in the lowlands of the Rio Negro valley showed a continuous forest with hyper humid conditions since $6000 \mathrm{cal}$ BP (D'Apolito et al., 2013).

\subsubsection{The late Holocene}

This period has been described as a wet climate among all the records from the Amazon region (e.g. Hooghiemstra and Berrio, 2007, Rull et al., 2013; Bush et al., 2016a) where a more evident influence by humans was observed in the landscapes (e.g. Lombardo et al., 2013; Roosevelt, 2013, Bush et al., 2016a). For this period, the high presence of fire signal in most of the records was attributed to humans instead to a dry climatic event, as most of the lake levels indicated wetter climates (Cordeiro et al.,2014).

\subsubsection{Anthropogenic influence}

The influence of the humans in the Amazon region nowadays is very extensive. The construction of roads, logging, mining and livestock farming among other activities are damaging what it is one of the most important sources of diversity and component of global cycles (Ter Steege et al., 2013; Levine et al., 2016). These devastating activities are the effect of several centuries of colonization and land transformation for the past 500 years (Roosevelt, 2013; Rodríguez-Zorro et al., 2015).Although the effect of ancient cultures in the Amazon landscapes is not clearly estimated yet (Roosevelt, 2013; McMichael et al., 2016; Bush et al., 2016). A number of examples of vast land alterations emerge from different locations in the 
Amazon lowlands (e.g. Roosevelt, 2013; Bush et al., 2016b and literature cited therein).

The most studied sites are the so called "terra preta" soils which are deep stratified anthropogenic soils with high amounts of nutrients that indicate past sedentary settlements (McMichael et al., 2014). The black color of the soils originates from charcoal, which is the result of human-made fires (e.g. charred seeds, leaves and bark,) (Roosevelt, 2013). The Amazonian terra preta soils contain deposits that are rich in pottery, stone artifacts, plant and animal food remains and house structural traces among others. These rich nutrient soils were developed along the basin, where resource-rich main streams or trading and cultural centers occurred (Roosevelt, 2013 and literature cited therein). The ages of these sites range between 500 and 2500 years BP (McMichael et al., 2014).

Other impressive examples of huge civilizations are located in the Bolivian savanna lowlands of the llanos the Moxos (e.g. Burbridge et al., 2004; Dickau et al., 2012; Lombardo et al., 2013; Whitney et al., 2014). Several earthworks such as ditched fields, platform fields, earth mounds, ridged fields and canals were found in a number of areas in the Llanos de Moxos (Dickau et al., 2012; Lombardo et al., 2013). Such sedentary societies were present in the late Holocene from ca. 500 to 1400 AD (Dickau et al., 2012). Archaeobotanical remains have also revealed the economic basis of these societies like manioc, squash, peanuts, cotton, yams and palms, in which maize was the most widespread (Dickau et al., 2012; Roosevelt, 2013).

Finally, the earth works located along the lowlands of Acre in Brazil and Bolivia reveal several geometric figures (geoglyphs). These geoplyhs are a result of excavated soil with dimensions from $0.5-1 \mathrm{~m}$ in height, $11 \mathrm{~m}$ in width and $1-3 \mathrm{~m}$ in depth. The diameter of the ring ditches varies from 90 to $300 \mathrm{~m}$ (Pärssinen et al., 2009), but the purpose of such constructions is still unknown. Some hypotheses point out to ceremonial or defensive sites that were constructed between 4000 and 750 cal BP (Pärssinen et al., 2009; Saunaluoma, 2012). 


\section{Aim and Objectives of the Project}

This project was developed with the aim to detect the late Quaternary vegetation changes in the western part of the Amazon region in response to the fluvial dynamics, climate and possible human impact. To pursue the aim, the methodology of this project was based on multi-proxy analyses, including microcharcoal, X-Ray fluorescence spectrometry (XRF), geochemistry and Loss on Ignition (LOI).

The following objectives have been addressed through this research:

- Reconstruct the vegetation dynamics in three different landscapes of the western Amazon region in Brazil.

- Identify the major drivers of vegetation changes between the different study sites.

- Detect possible regional climatic changes.

- Detect possible human disturbances and their impact on the vegetation composition. 


\section{References}

Almeida-Filho, R., Shimabukuro, Y.E., 2002. Digital processing of a Landsat-TM time series for mapping and monitoring degraded areas caused by independent gold miners, Roraima State, Brazilian Amazon. Remote Sensing of Environment 79:42-50.

Aragão, L.E.O., 2012. The rainforest's water pump. Nature 489: 217-218.

Barbosa, R.I., Miranda, I.S., 2004. Fitofisionomias e diversidade vegetal das Savanas se Roraima. Savanas de Roraima: Etnoecologia, biodiversidade e $\begin{array}{llll}\text { potencialidades agrossilvipastoris. } & \text { FEMACT }\end{array}$ (Phytophysiognomies and plant diversity of the Roraima savanas).

Behling, H., Hooghiemstra, H., 2000. Holocene Amazon rainforest-savanna dynamics and climatic implications: high-resolution pollen record from Laguna Loma Linda in eastern Colombia. Journal of Quaternary Science 15: 687-695.

Behling, H., Keim, G., Irion, G., et al., 2001. Holocene environmental changes in the Central Amazon basin inferred from Lago Calado (Brazil). Palaeogegraphy, Palaeoclimatology, Palaeoecology 173: 87-101.

Beserra Neta, L.C., Tavares, S.S., Costa, M.L., 2015. Tepequém mountains: a relict landscape in the northern Amazon. In: Vieira et al (eds) Landscapes and Landforms of Brazil, Springer Science pp. 265-272.

Birks, H.J.B., Birks, H.H., 1980. Quaternary Palaeoecology. Edward Arnold, London.

Birks,H.J.,2012. Ecological palaeoecology and conservation biology: controversies, challenges, and compromises. International Journal of Biodiversity Science, ecosystem Services \& Management 8: 292-304.

Burbridge, R.E., Mayle, F.E., Killeen, T.J., 2004. Fifty-thousand-year vegetation and climate history of Noel Kempff Mercado National Park, Bolivian Amazon. Quaternary Research 61: 215-230. 
Bush, M.B., De Oliveira, P.E., Colinvaux, P.A., Miller, M.C., Moreno, J.E., 2004. Amazonian paleoecological histories: One hill, three watersheds. Palaeogeography, Palaeoclimatology, Palaeoecology 214: 359-393.

Bush,M.B., Silman, M., Toledo,M.B., et al., 2007. Holocene fire and occupation in Amazonia: records from two lake districts. Philosophical transactions of the Royal Society B 362: 208-218.

Bush, M.B., Correa-Metrio, A., McMichael, C.H., et al., 2016a. A 6900-year history of landscape modification by humans in lowland Amazonia. Quaternary Science Reviews 141: 52-64.

Bush, M.B., McMichael, C.H.,Piperno, D., et al., 2016b. Anthropogenic influence on Amazonian forests in pre-history: An ecological perspective.Journal of Biogeography 42:2277-2288.

Bustamante, M.G., Cruz, F.W., Vuille, M., et al., 2016. Holocene changes in monsoon precipitation in the Andes of NE Peru based on $\mathrm{d}^{18} \mathrm{O}$ speleothem records. Quaternary Science Reviews 146: 274-287.

Cheng, H., Sinha, A., Cruz, F.W., et al., 2013. Climate change patterns in Amazonia and biodiversity. Nature communications 4:1411.

Correa-Metrio, A., Cabrera, K.R., Bush, M., 2010. Quantifying ecological change through discriminant analysis: a paleoecological example from the Peruvian Amazon. Journal of Vegetation Science 21: 695-704.

Cordeiro, R.C., Turcq, B., Moreira., L.M., et al., 2014. Palaeofires in Amazon: Interplay between land use change and palaeoclimatic events. Palaeogeography, Palaeoclimatology, Palaeoecology 415: 137-151.

D'Apolito, C., Absy, M.L.,Latrubesse, E.M., 2013. The Hill of Six Lakes revisited : new data and re-evaluation of a key Pleistocene Amazon site. Quaternary Science Reviews 76: 140-155.

Dickau, R., Bruno, M.C., Iriarte,J., et al., 2012. Diversity of cultivars and other plant resources used at habitation sites in the Llanos de Mojos, Beni, Bolivia: 
evidence from macrobotanical remains, starch grains, and phytoliths. Journal of Archaeological Science 39:357-370.

Drumond,A., Marengo,J., Ambrizzi, T., 2014. The role of the Amazon Basin moisture in the atmospheric branch of the hydrological cycle: a Lagrangian analysis. Hydrology and Earth System Sciences 18: 2577-2598.

Faegri, K., Iversen, J., 1989. Textbook of Pollen Analysis, fourth ed. Wiley, New York.

Fearnside, P.M., 2006. Desmatamento na Amazônia: dinâmica, impactos e controle. Acta Amazonica 36: 395-400. (Deforestation in the Amazon: dynamics, impact and control).

Ferreira, L.V., Venticinque, E., Almeida, S., 2005. O desmatamento na Amazônia e a importância das áreas protegidas. Estudos Avançados 19: 158-166. (The Deforestation in the Amazon and the importance of the protected areas).

Hermanowski, B., Costa, M.L., Behling, H., 2015. Possible linkages of palaeofires in southeast Amazonia to a changing climate since the Last Glacial Maximum. Vegetation History and Archaeobotany 24: 279-292.

Hooghiemstra, H., Berrio, J.C., 2007. South America: Pollen record from the Colombian savannas. In: Elias S (ed), Encyclopedia of Quaternary Science. Elsevier pp 2,654-2,659

Hoorn, C.,Roddaz, M., Dino, R., et al., 2010a. The Amazonian Craton and its influence on past fluvial systems (Mesozoic-Cenozoic, Amazonia). In: Hoorn, C., Wesselingh, F.P. (eds) Amazonia: landscape and species evolution A look into the past. Wiley-Blackwell ,pp.103-122.

Hoorn, C., Wesselingh, F.P., Ter Steege, H., et al., 2010b. Amazonia Through Time: Andean Uplift, Climate Change, Landscape Evolution, and Biodiversity. Science 330: 927-931.

Instituto Brasileiro de Geografia e Estadistíca (IBGE) 2012. Manual técnico da vegetação Brasileira. Rio de Janeiro, Brazil. pp. 271. (Technical manual of the Brazilian Vegetation). 
Instituto Nacional de Pesquisas Espaciais (INPE), 2017. Ministério da Ciencia, Tecnologia e Inovaçao. Available at: http://www.inpe.br. (Accessed on January 2017 )(National Institute of Spatial research).

Irion,G., Bush, M.B., Mello, J.A.N., et al., 2006. A multiproxy palaeoecological record of Holocene lake sediments from the Rio Tapajós, eastern Amazonia. Palaeogeography, Palaeolimnology, Palaeoecology 240: 523-535.

Irion, G., Kalliola, R., 2010. Long-term landscape development processes in Amazonia. In: Hoorn, C., Wesselingh, F.P. (eds) Amazonia: landscape and species evolution A look into the past. Wiley-Blackwell ,pp. 185-197.

Junk,W.J., Piedade, M.T.F., 2010. An introduction to south American wetland forests: distribution, definitions and general characterization. In: Junk, W.J., Piedade, M.T.F., Wittmann, F., Schöngart, J., Parolin, P. (Eds.) Amazonian Floodplain Forests: Ecophysiology, Biodiversity and Sustainable management. Springer, New York, pp. 3-25.

Lani, J.L., Gomes, M.A., Pereira, N.W., 2008. Tipologias florestais do município de Rio Branco-AC. Boletin Tecnico 15, 54. Programa de Zoneamento Econômico, Ambiental,Social e Cultural de Rio Branco-AC (ZEAS), p.56. (Forests typologies from the County of Rio Branco-AC).

Latrubesse, E., 2012. Amazon Lakes. In: . Bengtsson, L., Herschy,R., and Fairbridge, R. (Eds) Lakes and Reservoirs. Springer Verlag, 13-26.

Levine, N.M., Zhang, K., Longo, M., et al., 2016. Ecosystem heterogeneity determines the ecological resilience of the Amazon to climate change. Proceedings of the National Academy of Sciences 113: 793-797.

Lewis, S.L., Brando, P.M., Phillips, O.L., et al., 2011. The 2010 Amazon Drought. Science 331: 554.

Lombardo, U., Denier, S., May, J.H., et al., 2013. Humaneenvironment interactions in pre-Columbian Amazonia: The case of the Llanos de Moxos, Bolivia. Quaternary International 312: 109-119. 
Lundberg, J.G., Pérez, M.H.S., Daduhl, W.M., et al., 2010. The Amazonian Neogene fish fauna. In: Hoorn, C., Wesselingh, F.P. (eds) Amazonia: landscape and species evolution A look into the past. Wiley-Blackwell, pp.281-300.

Mayle, F.E., Burbridge, R., Killeen, J.T., 2000. Millennial-Scale Dynamics of Southern Amazonian Rain Forests. Science 290: 2291-2294.

McGee, D., Donohoe, A., Marshall, J., Ferreira, D., 2014. Changes in ITCZ location and cross-equatorial heat transport at the Last Glacial Maximum, Heinrich Stadial 1, and the mid-Holocene. Earth and Planetary Science Letters 390: 6979.

McMichael, C.H., Palace, M.W., Bush, M.B., et al., 2014. Predicting pre-Columbian anthropogenic soils in Amazonia.Proceedings of the Royal Society B 281: 20132475.

Montero, J.C., 2012. Floristic Variation of the Igapó Forests along the Negro River, Central Amazonia. Ph.D Thesis, University of Freiburg, Germany.

Montero, J.C., Latrubesse, E.M., 2013. The igapó of the Negro River in central Amazonia: Linking late-successional inundation forest with fluvial geomorphology. Journal of South American Earth Sciences 46: 137-149.

Ministerio do Meio Ambiente (MMA), 2006. Mapa de cobertura VegetalAmazônia-Secretaria de Biodiversidade e Florestas-SBF. Available at: http://www.mma.gov.br/ (Accessed on January 2016). (Map of vegetation cover- Amazon region).

Nascimento, F.A., Tavares-Junior S.S., Beserra-Neta L.C., 2012. Estudo dos compartimentos geomorfológicos na serra do tepequém - RR, através de fotointerpretação em imagens de sensores remotos e produtos integrados via ihs. Revista Geonorte 2: 1,464-1,474. ( Geomorphological studies form the compartments of the Serra do Tepequém-RR, through remote sensing imagines and integrated products via ihs).

Nobre, C. A., Obregón, G. O., Marengo, J. A., et al., 2009. Characteristics of Amazonian Climate: Main Features. In: Keller, M., Bustamante,M., Gash, J., 
Silva Dias, P., (eds) Amazonia and Global Change American Geophysical Union, Washington, D. C.pp. 149-162.

Pärssinen, M., Schaan, D., Ranzi, A., 2009. Pre-columbian geometric earthworks in the upper Purús: a complex society in western Amazonia. Antiquity 83: 1084-1095.

Roosevelt, A.C., 2013. The Amazon and the Anthropocene: 13,000 years of human influence in a tropical rainforest. Anthropocene 4: 69-87.

Rodríguez-Zorro, P.A., Enters, D., Hermanowski, B., et al., 2015. Vegetation changes and human impact inferred from an oxbow lake in southwestern Amazonia, Brazil since the 19th century. Journal of South American Earth Sciences 62: 186-194.

Rull, V., Montoya, E., Nogué, S., et al., 2013. Ecological palaeoecology in the neotropical Gran Sabana region: Long-term records of vegetation dynamics as a basis for ecological hypothesis testing. Perspectives in Plant Ecology, Evolution and Systematics 15:338-359.

Saunaluoma, S., Schaan, D., 2012. Monumentality in western Amazonian formative societies: geometric ditched enclosures in the Brazilian state of Acre. Antiqua 2: 1-11.

Silva J.M.C., Rylands, A.B., Fonseca, G.A.B., 2005. The Fate of the Amazonian Areas of Endemism. Conservation Biology 19: 689-694.

Spracklen, D.V., Arnold, S.R., Taylor, C.M., 2012. Observations of increased tropical rainfall preceded by air passage over forests. Nature 489: 282-286

Ter Steege, H., Pitman, N.C.A., Sabatier, D., et al., 2013. Hyperdominance in the Amazonian tree flora. Science 342: 1243092.

Wanderley-Filho, J.R., Eiras, J.F., Cunha, P.R.C., et al., 2010. The Paleozoic Solimões and Amazonas basins and the Acre foreland basin of Brazil. In: Hoorn, C., Wesselingh, F.P. (eds) Amazonia: landscape and species evolution A look into the past. Wiley-Blackwell, pp.29-37. 
Wang, X., Edwards, L.R., Auler,A.S., et al., 2017. Hydroclimate changes across the Amazon lowlands over the past 45,000 years. Nature 541: 204-207.

Weng, C., Bush, M.B., Athens, S., 2002. Holocene climate change and hydrarch succession in lowland Amazonian Ecuador. Review of Palaeobotany and Palynology 120: 73-90.

Willis, K., J. Araújo, M.B., Bennett, K.D., et al., 2007. How can a knowledge of the past help to conserve the future? Biodiversity conservation and the relevance of long-term ecological studies. Philosophical Transactions of the Royal Society B 362: 175-186.

Whitney, B.S., Dickau, R., Mayle, F.E., et al., 2014. Pre-Columbian raised-field agriculture and land use in the Bolivian Amazon. The Holocene 24: 231-241. 


\section{CHAPTER 2}

\section{Vegetation changes and human impact inferred from an oxbow lake in southwestern Amazonia, Brazil since the 19th century.}

Paula A. Rodríguez-Zorro ${ }^{\mathbf{a}^{*}}$, Dirk Enters ${ }^{\mathbf{b}}$, Barbara Hermanowski ${ }^{\mathbf{a}}$, Marcondes Lima da Costa ${ }^{\mathrm{c}}$, Hermann Behling ${ }^{\mathbf{a}}$

a. University of Göttingen, Albrecht-von-Haller Institute for Plant Sciences, Department of Palynology and Climate Dynamics, Untere Karspüle 2, 37073 Göttingen, Germany

b. GEOPOLAR, Institute of Geography, University of Bremen, 28359 Bremen, Germany

c. Universidade Federal do Pará, Centro de Geociências, Departamento de Geoquímica e Petrologia, Av. Augusto Correa 1, Guamá, 66075-900 Belém, Brazil

Published in the Journal of South American Earth Sciences,

2015http://dx.doi.org/10.1016/j.jsames.2015.06.003 


\section{Abstract}

Pollen and X-ray fluorescence spectrometry (XRF) analyses from a $272 \mathrm{~cm}$-long sediment core of Lago Amapá, an oxbow lake in western Amazonia, reveal the first palaeoecological investigation of late Holocene sediments in Acre state, Brazil. Radiocarbon dating of older sediments failed due to re-deposition of organic material but a historical map suggests that lacustrine deposition started at 1900 AD. We detected two periods of changes in sediment and vegetation, dominated by pioneer taxa especially Cecropia. The first period around $1900 \mathrm{AD}$ is documenting an initial oxbow lake, with regular fluvial input (high Ti) and low accumulation of organic matter (low inc/coh ratio). During that period Andean pollen taxa originating from Peruvian Andean headwaters were deposited. A fully lacustrine phase started about $1950 \mathrm{AD}$ and is characterized by prolonged periods of stagnant water (low Fe/Mn ratio). The increase of pioneer taxa, sedimentation rates and a reduction of most of the XRF element counts point to a period during which Lago Amapa was a more isolated lake which was flooded only during exceptional severe flood events and is catching mainly anthropogenic disturbances. The extensive human influence during this period was assumed by 1) the high occurrence of pioneer taxa and the absence of charcoal which could indicate changes in vegetation possibly as a result of logging, 2) the $\mathrm{Ca}$ and $\mathrm{Ti} / \mathrm{K}$ ratio which reflect changes to a local sediment source, and 3) comparison of Landsat images from the last 30 years which shows broad changes in vegetation cover and land transformation in the peripheral areas of the oxbow lake.

\section{Key words}

Brazil, Acre River, floodplain, oxbow lake, pollen analysis, XRF analysis, Amazon rainforest, human impact, late Holocene 


\section{Introduction}

Alluvial plains and associated features such as oxbow lakes can be interpreted as a succession of different palaeohydrological events (Morais et al., 2008). In the Brazilian Amazon floodplains, especially in the southwestern part, strong fluvial dynamics control the vegetation succession along the floodplain (Salo et al., 1986; Kalliola et al., 1991; Morais et al., 2008). Water and transported sediments are the main factors for river ecology in recycling nutrients to the biota. During floods erosive and depositional sites develop on the floodplain and form complex habitats. This dynamic affects the distribution, diversity and functioning of riparian vegetation (Kalliola et al., 1991; Latrubesse and Kalicki, 2002; Morais et al., 2008; Stevaux et al., 2013). The vegetation succession is initiated on depositional bars which are exposed during the annual low water season. Although colonized immediately after their exposure, these sites and their vegetation are continuously changing with the river processes (Puhakka et al., 1992). On well drained floodplain sites, the most important colonist species are trees and shrubs which occupy newly exposed sites. These species resist severe flood damage and can tolerate considerable coverage by sediments (Kalliola et al., 1991).

Oxbow lakes are typical features of the southwestern Amazonian meandering rivers (Räsänen et al., 1991; Kalliola et al., 1992; Toivonen et al., 2007; Latrubesse, 2012). They are formed by active river channel dynamics, together with an intensive lateral and vertical floodplain aggradation plus the high annual seasonal discharge variability (Räsänen et al., 1991; Latrubesse and Kalicki, 2002; Wójcicki, 2006; Junk and Piedade, 2010). The sediments of these lakes are mainly composed of fine grained mineral particles which are deposited during annual inundations (Räsänen et al., 1991).

Several studies were performed on the western Amazon floodplain trying to understand palaeohydrological and vegetation changes mainly on the Peruvian and Bolivian Amazon (Salo et al., 1986; Räsänen et al., 1991; Burbridge et al., 2004; Bush et al., 2007a, b; Mayle et al., 2007) as well as in the Brazilian Amazon(e.g. Behling and Costa, 2000; Behling et al., 2001). They report high sedimentation rates and different phases of vegetation succession during the late Quaternary, with a tendency to wetter conditions towards the late Holocene. Wetter climatic conditions during the late Holocene are also indicated by the expansion of the 
Amazon rainforest into the savanna in the Llanos Orientales of northwestern Amazonia (e.g. Behling and Hooghiemstra, 1997, 1999) and into the savanna of southwestern Amazonia (Mayle et al., 2004, 2007).

In addition, some of these studies showed a strong transformation of the landscape by pre-Columbian civilizations. In the case of llanos de Moxos in the Bolivian Amazon, complex drainage systems were developed (Mayle et al., 2007; Erickson, 2008, 2010; Lombardo, 2011). Ditches and causeways were created to get better drainage by cutting through the palaeo-levees or by taking water from the flat savannas to the rivers (Lombardo, 2013). Different proxies were used to detect the signal of human influence along these areas like charcoal, pollen of pioneer species and cultivated plants (Zea mays, Manihot esculenta, Cucurbita sp., Gossypium sp.) (Dickau, 2012). These proxies show that landscape transformation on llanos de Moxos already took place around $400 \mathrm{BC}$ by pre-Hispanic people (Saunaluoma and Schaan, 2012).

It is also known that the landscape has been transformed in Acre State (western Brazil) before Hispanic and Portuguese settlement. The main alterations in this region are geometric earthworks (geoglyphs) that were made by natives (Schaan et al., 2007; Erickson, 2008; Pärssinen et al., 2009). According to Saunaluoma and Schaan (2012) the most intensive period of geometric enclosure use occurred between $200 \mathrm{BC}$ and AD 900.

After the Portuguese conquest (16th century) landscape alterations in Acre State resulted from logging industry, livestock farming and urban expansion. The capital city of the state, Rio Branco, is one of the most affected with 28 percent of deforested territory between 1994 and 2007 (Lani et al., 2008; Silva et al., 2008; Figueiredo, 2010). Changes in land cover are linked to the development of the city which started when the rubber industry boom began in the 19th century due to the huge amount of Hevea brasiliensis tree plantations in the area (Leite, 2007). Until now no palaeoecological studies confirm the anthropogenic influence on vegetation establishment in this area.

As a first palaeoecological approach on late Holocene vegetation changes on the Acre River floodplain, our study focuses on the different changes in vegetation inferred from the sediment deposits in the oxbow lake Lago Amapá, including the 
expansion of Rio Branco City and the influence of the Acre River on the lake. Radiocarbon dating, pollen and X-ray fluorescence spectrometry (XRF) data were used for this pilot study to investigate the potential of oxbow lakes in western Amazonia for palaeoecological research.

\section{Study area}

Lago Amapá is located southwest of Rio Branco City in Acre State, Brazil $\left(10^{\circ} 02^{\prime} 43.5^{\prime \prime} \mathrm{S} 67^{\circ} 51^{\prime} 18.2^{\prime \prime} \mathrm{W}, 153 \mathrm{~m}\right.$ elevation) (Fig.1). It is a $3 \mathrm{~km}$-long, U-shaped oxbow lake of the Acre River. This river has a single-sinuous channel and asymmetric, complex meanders alternating with straight segments (Stevaux et al., 2010). Its basin is located on Tertiary claystones, siltstones and fine sandstones of the Solimões Formation. Acre River originates from Peruvian headwaters and carries a significant sediment load from the Andes. The climate in Rio Branco City is tropical humid (Am, Köppen classification) with an annual mean temperature of $25 \mathrm{C}$ and $1900 \mathrm{~mm}$ annual precipitation. It has a seasonal variability with two main seasons: a dry season from May to October and a wet season from November to April (Duarte, 2006; INMET, 2014).

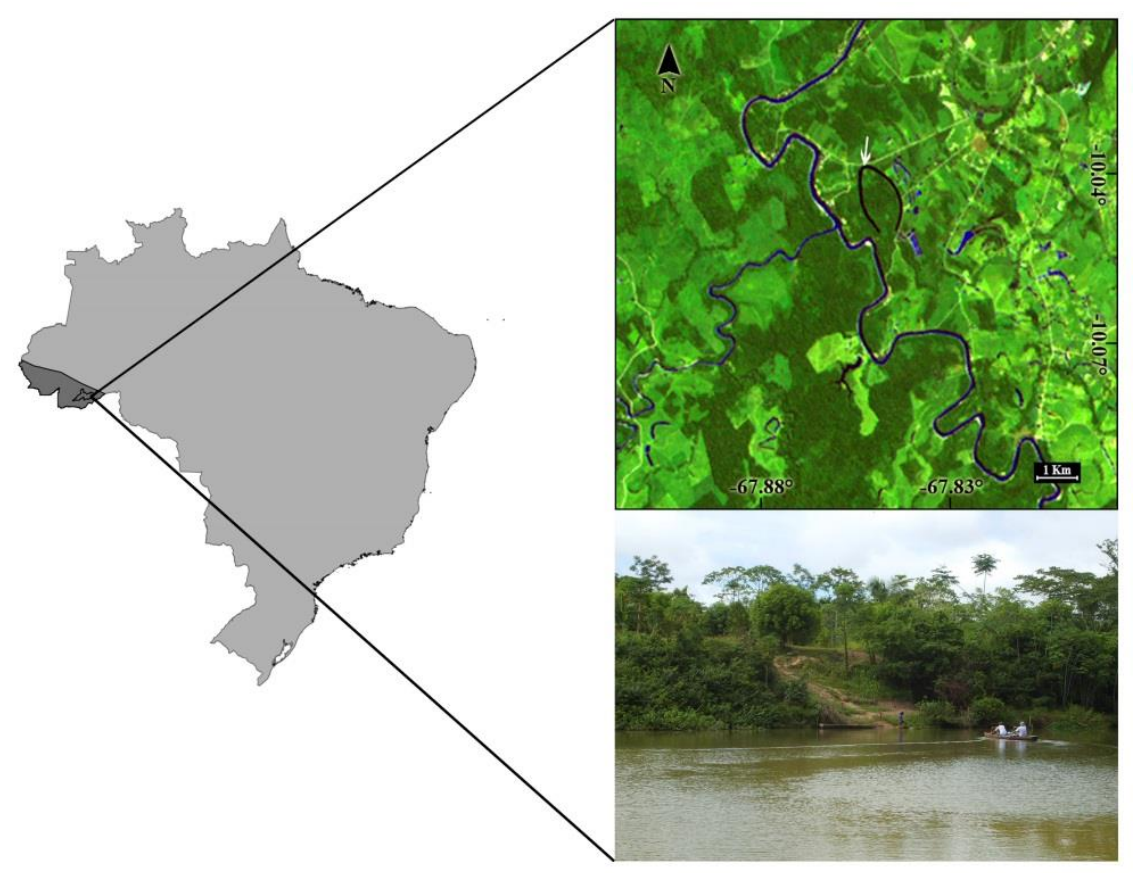

Fig 1. Location, Landsat 5 image and picture from Lago Amapá oxbow lake. On the right side is shown a semi natural color map from the study area done by Landsat 5 shortwave infrared band 7 , 
near infrared band 5 and green band 3. The white arrow is showing the coring site. The picture is showing the surrounding vegetation in the lake.

The current vegetation in the area is strongly altered and consists of large areas of pastures, crops and urban settlement. The natural vegetation is semi-evergreen tropical rainforest with a mixture of palm trees and bamboo. The lake is surrounded by small patches of tropical rain forest (Lani et al., 2008), crops and fishery ponds. The main tree families are Moraceae, Fabaceae, Bignoniaceae, Caesalpinaceae, Meliaceae, Apocynaceae, Euphorbiaceae, Bombacaceae and Lecythidaceae besides several palm species (Lani et al., 2008).

\section{Materials and methods}

A $272 \mathrm{~cm}$-long core was taken with a Livingstone piston corer in 2009, in the convex part of the lake (Fig. 1). For palynological analysis 35 subsamples $\left(0.5 \mathrm{~cm}^{3}\right)$ were taken in $8 \mathrm{~cm}$ intervals along the core. Pollen samples were prepared using standard pollen preparation techniques (Faegri and Iversen, 1989). One tablet of exotic marker (Lycopodium clavatum) was added per sample for the calculation of pollen concentration (Stockmarr, 1971). Almost all pollen samples were counted to a sum of 300 pollen grains, except for a few samples with low pollen content which were counted to a sum of 100 or 200 pollen grains. Two samples (104 and $264 \mathrm{~cm}$ ) had a very low pollen content ( $<100$ pollen grains) and were excluded from the pollen diagram. Pollen and spore identification was based on reference literature (Roubik and Moreno, 1991; Carreira et al., 1996) and a pollen reference collection at the Department of Palynology and Climate Dynamics (University of Göttingen, Germany).The grouping of the pollen taxa into the ecological groups has been done according to Salo et al. (1986), Kalliola et al. (1991) and modern vegetation studies done by Lani et al. (2008).

The zonation of the pollen diagram was created in base of important changes in the pollen assemblages and in cluster analysis of pollen data performed with CONISS (Grimm, 1987). Spores were excluded from the pollen sum. The Shannon index was calculated to show pollen diversity along the record. All calculations and illustrations were done with TILIA (Grimm, 2011).

Radiocarbon dating on 9 samples was performed by Accelerator Mass Spectrometry (AMS) at the AMS laboratory at the University of 
Erlangen/Nürnberg and at the AMS NTUAMS Laboratory of the National University of Taiwan (Table 1). Radiocarbon dates were calibrated with postbomb curves using the Southern Hemisphere zone 3 compilation (Hua et al., 2013) as well as the curve IntCal13 for the northern hemisphere (Reimer et al., 2013). Calibration was performed with R Development Core Team (2015), using the package Clam (Blaauw, 2010).

Non-destructive XRF scanning was performed with an Itrax Corescanner (Cox Analytical Systems) at the University of Bremen, Institute of Geography, Germany. The split cores were scanned at a resolution of $0.5 \mathrm{~mm}$ using a Mo X-ray tube (30 $\mathrm{kV}, 18 \mathrm{~mA}$ ) with a dwell time of $10 \mathrm{~s}$ per step. To improve the signal-to-noise ratio four consecutive spectra were later combined and reprocessed with the scanning software (Q-spec, Cox Analytical Systems) to achieve a spatial resolution of $2 \mathrm{~mm}$ with a dwell time of $40 \mathrm{~s}$. Raw element data (integrated peak areas as total counts) were normalized by the coherent scatter radiation (coh) to minimize matrix effects

Table 1 List of the AMS radiocarbon dates from Lago Amapá. (1= AMS Laboratory University of Erlangen/Nürnberg, 2=AMS NTUAMS Laboratory of the National University of Taiwan, *pMC values).

\begin{tabular}{|c|c|c|c|c|}
\hline $\begin{array}{c}\text { Depth } \\
\text { (cm) }\end{array}$ & Lab code & Dated material & 14C yr BP & $\begin{array}{c}\text { Age cal AD } \\
\text { (weighted average, } \\
2 \sigma)\end{array}$ \\
\hline 43 & Erl-138291 & Leaf fragment & $123,29 \pm 0,65^{*}$ & 1961-1985 \\
\hline 88 & Erl-138301 & Leaf fragment & $129,27 \pm 0,70^{*}$ & $1962-1982$ \\
\hline 107 & Erl-13831 & Bulk sediment & $131,03 \pm 0,71^{*}$ & $1962-1980$ \\
\hline 180 & NTUAMS-339² & Bulk sediment & $1864 \pm 15$ & $86-214$ \\
\hline 181 & Erl-13832 ${ }^{1}$ & Bulk sediment & $163 \pm 84$ & $1526-1954$ \\
\hline 210 & Erl-13833¹ & Bulk sediment & $698 \pm 90$ & $1161-1425$ \\
\hline 243 & NTUAMS-720² & Leaf fragment & $2035 \pm 28$ & 156 BC -48 \\
\hline 257 & Erl-138341 & Bulk sediment & $467 \pm 85$ & $1304-1635$ \\
\hline 272 & NTUAMS-338² & Bulk sediment & $2759 \pm 34$ & 994-829 BC \\
\hline
\end{tabular}


Landsat 5 images were obtained from the web page of the Brazilian National Institute for Space research (INPE, 2014). These semi natural color images are composed of the shortwave infrared band 7 , the near infrared band 5 and the green band 3 .

\section{Results}

\subsubsection{Stratigraphy}

The sediments of the studied core are composed of alternating dark and light gray fine detritus mud with silt to clayey silt (Table 2). The dark gray bands correspond to organic rich, anoxic sediments containing few leave fragments. The light gray bands are related to increased minerogenic fluvial input during seasonal floods, indicating high lake and river stages. After some hours of exposure the core oxidized, resulting in a more or less homogenous ochreous colored record.

Table 2 Stratigraphy of the Lago Amapá core.

\begin{tabular}{cl}
\hline Core depth $\mathbf{( c m )}$ & \multicolumn{1}{c}{ Description of the sediment } \\
\hline $0-100$ & $\begin{array}{l}\text { Gray detritus mud (oxidized) with clayey-silty material with fine dark } \\
\text { gray bands } \\
100-114\end{array}$ \\
$114-140$ & Gray fine detritus mud with thick gray bands \\
$140-217$ & Gands of clayey ochreous (oxidized) and fine detritus mud \\
$217-257$ & Gray fine detritus mud with thick gray bands \\
$257-272$ & Bands of silty-clayey ochreous (oxidized) and gray fine detritus mud \\
\hline
\end{tabular}

\subsubsection{Chronology}

Three of the 6 dated samples from the AMS laboratory at the University of Erlangen Nürnberg gave a modern age (Table 1). The other three below $180 \mathrm{~cm}$ depth show one age reversal (Erl-13833). The three samples submitted to the AMS NTUAMS Laboratory of the National University of Taiwan are considerably older, without reversals but pointing to an age of $900 \mathrm{cal} \mathrm{yr} \mathrm{BC}$ for the bottom of the core. Another independent chronological marker is a map suggesting that the cut-off of 
the meander was after the William Chandless expedition between 1861 and 1868 (Ishii, 2011).

Based on the evidence given in the historical map by Chandless (1866) and on other studies performed in Amazon oxbow lakes (Räsänen et al., 1991, Plotzki et al., 2013), we reject all dates except the three youngest ones and assume a bottom age of the core of around $1900 \mathrm{AD}$. This results in very high sedimentation rates of on average $2 \mathrm{~cm} /$ year.

\subsubsection{Pollen diagram}

In total, 60 pollen and spore taxa were identified consisting of five ecological groups: Pioneers, Swamp and floodplain, Terra firme (non-flooded) forest, Andean taxa and Palms. Andean taxa include pollen grains which normally occur not in the Amazon lowland and were probably transported by the Acre River from higher elevated sites into the lake.

Cluster Analysis made by CONISS for pollen data resulted in two main zones LA-I $(272-160 \mathrm{~cm})$ and LA-II $(160-0 \mathrm{~cm})$ of the pollen diagram. LA-II is divided in two subzones LA-IIa $(160-80 \mathrm{~cm}$ ) and LA-IIb $(80-0 \mathrm{~cm})$ (Fig. 2). Pollen concentration is relatively low along the record with values between 3600 and 35,000 grains $/ \mathrm{cm}^{3}$.

The record is dominated by the pioneer taxa especially Cecropia (Figs. 2 and 3). The Shannon index is showing a decreasing trend of pollen and spore diversity from the bottom to the top of the record.

\subsubsection{Pollen zone LA-I $(272-160 \mathrm{~cm})$}

This zone is characterized by high values of pioneer taxa (20-60\%), mainly of Cecropia with oscillations between 15 and 50\%. There is a high representation of swamp and floodplain forest (30-40\%) in particular Moraceae/Urticaceae (20-40\%) and Salix (10-20\%); both reach their highest abundances of the record. The Terra firme forest group also has high pollen values (20-30\%) represented by different taxa like Acalypha (1-7\%), Sapindaceae (1-7\%) and Melastomataceae (2-9\%). Andean taxa reach their highest representation along the record $(<10 \%)$. Palms and spores are represented by less than $10 \%$ (Figs. 2 and 3). Pollen concentration is low with values between 3600 and 15,000 grains $/ \mathrm{cm}^{3}$. Pollen diversity is constant and shows the highest of the Lago Amapá record. 


\subsubsection{Pollen zone LA-IIa $(160-80 \mathrm{~cm})$}

At the beginning of the zone, pollen of pioneer taxa represent less than $60 \%$ and at the end of the zone increase to $87 \%$. Cecropia is the main taxa of the group (max. $80 \%)$; the abundance of other pioneer taxa Poaceae $(2-6 \%)$, Trema $(1-8 \%)$ and Asteraceae (1-8\%) also increases. Representation of swamp and floodplain forest taxa is reduced to $15-30 \%$ and decreases to $6-12 \%$ at end of the zone. Moraceae/Urticaceae pollen is less abundant (down to 7\%) and Salix pollen is only represented $(<5 \%)$ at the beginning and at the end of the zone. Terra firme pollen taxa have also a trend to diminish their abundances (5-20\%); Acalypha has low values $(<5 \%)$ at the middle of the zone (Figs. 2 and 3). Andean taxa consists only of a small amount of Ilex pollen $(<1 \%)$ at the beginning of the zone. Pollen concentration is the lowest in the whole record with 3600 and 7200 grains $/ \mathrm{cm}^{3}$. Diversity declines to low values at the end of the zone.

\subsubsection{Pollen zone LA-IIb $(80 e 0 \mathrm{~cm})$}

Pollen of pioneer taxa remains frequent in this zone (50-86\%). Cecropia (50-80\%) and Poaceae $(1-10 \%)$ are well represented. Abundance of swamp and floodplain forest pollen increases (10-30\%) with Moraceae/Urticaceae (5-20\%), Salix $(<5 \%)$ and other taxa with lower values (Figs. 2 and 3). Terra firme taxa have a slight increase in their abundance $(7-25 \%)$. Acalypha $(<5 \%)$ occurs at the top of the zone. Pollen concentration is the highest of the record, with values between 6000 and 35,000 grains/cm 3 and the diversity index starts to increase again 


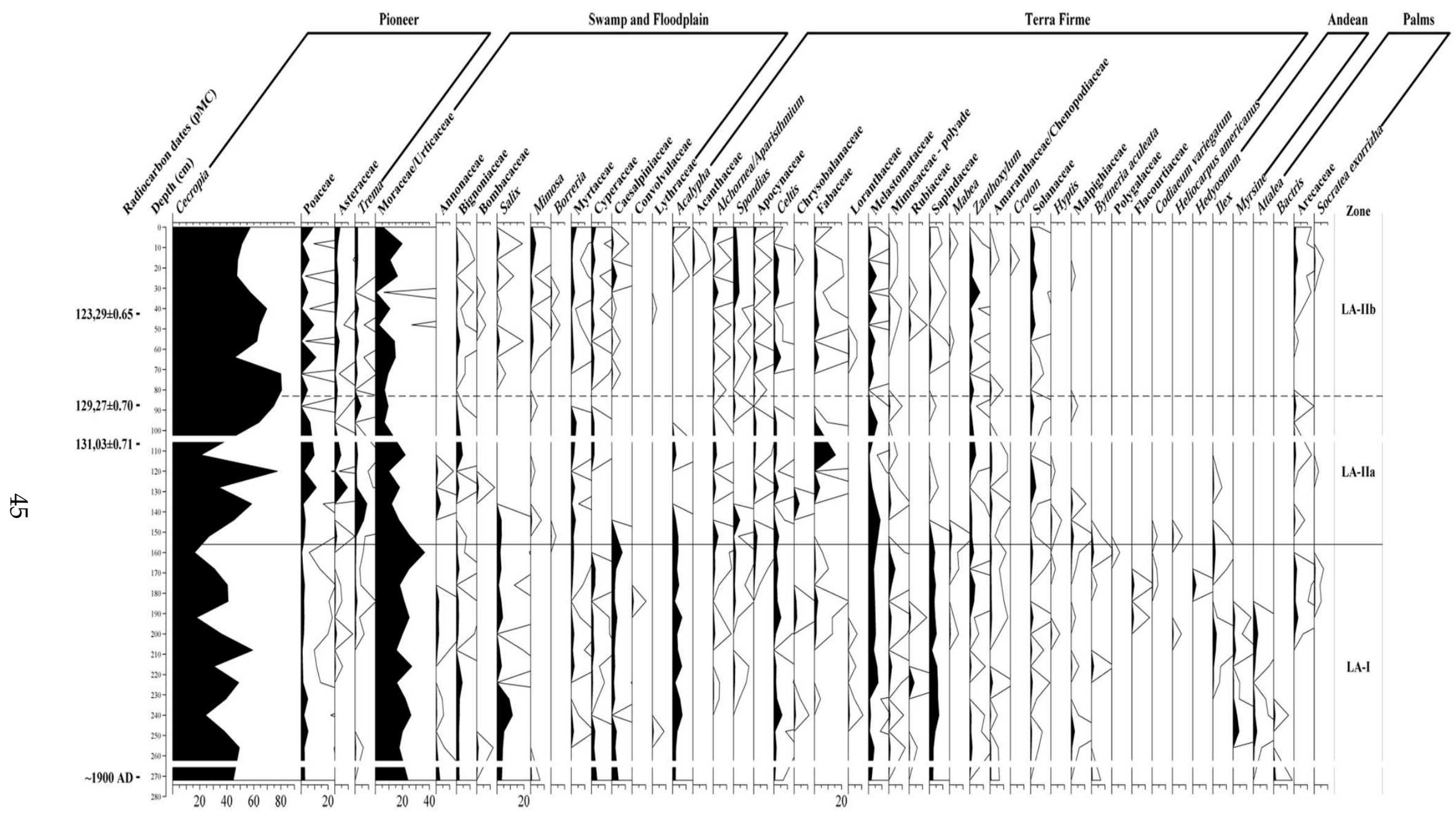

Fig. 2. Summary pollen percentage diagram of Lago Amapá showing the used radiocarbon dates (pMC), vegetation groups, pollen concentration, Shannon Index and the CONISS dendrogram. 


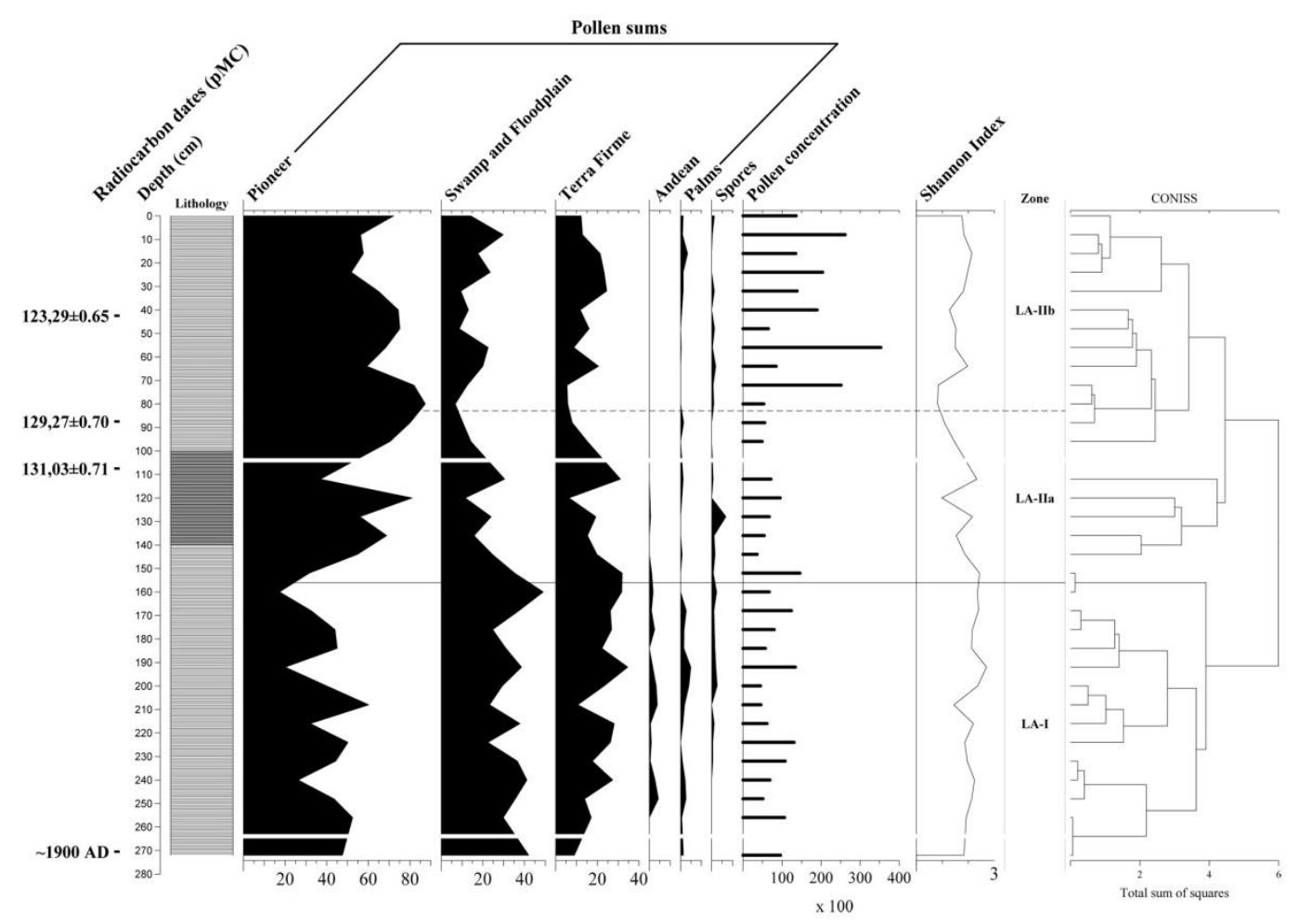

Fig. 3. Summary pollen percentage diagram of Lago Amapa showing the used radiocarbon dates (pMC), vegetation groups, pollen concentration, Shannon Index and the CONISS dendrogram.

\subsubsection{XRF analysis}

The XRF data show a decreasing trend in coh-normalized $\mathrm{Si}$, Ti and Ca towards the top of the core (Fig. 4). Si and Ti are also highly correlated with other lithogenic elements like $\mathrm{K}$ and $\mathrm{Rb}$ (data not shown) and their peaks generally correspond to lighter colored sediment layers. Conversely, low values are related to dark gray bands. The Fe/Mn ratio decreases in the youngest sediments, but shows a large scatter at depths below $150 \mathrm{~cm}$. The ratio of coherent to incoherent scattering (inc/coh) displays a reverse trend and increases from values below 3.4 to above 4.0. The $\mathrm{Ti} / \mathrm{K}$ ratio shows a slightly decreasing trend from the bottom of the core until around $120 \mathrm{~cm}$ sediment depth and then slightly increases again. No changes are detectable for $\mathrm{Pb}$ as well as other elements commonly indicative of anthropogenic pollution such as $\mathrm{Zn}, \mathrm{Cu}$ or $\mathrm{Hg}$ (data not shown). 


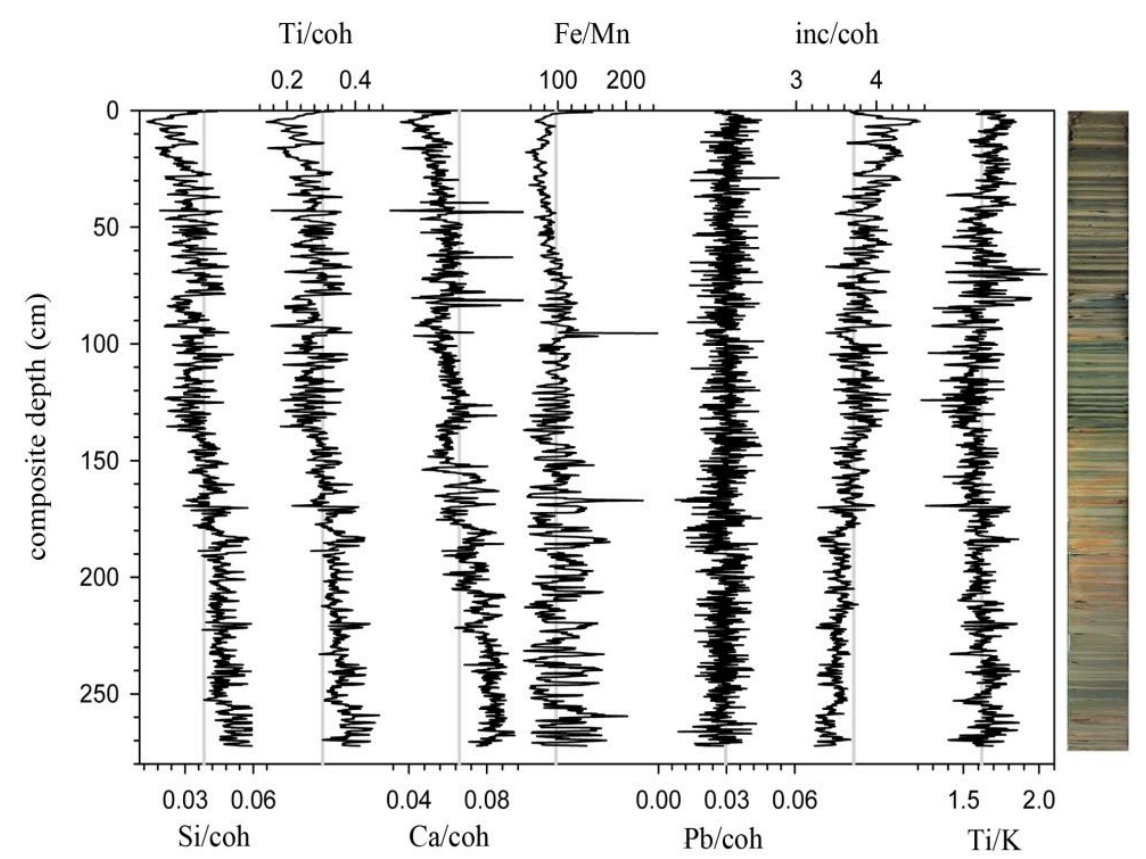

Fig. 4. XRF scanning results (normalized by coherent radiation) and optical image of the composite sediment record of Lago Amapá. Vertical lines denote the mean for each diagramed parameter. The optical image was taken with the RGB camera of the Itrax core scanner, enhanced in contrast and horizontally exaggerated.

\section{Interpretation and discussion}

\subsubsection{Chronology of Lago Amapá core}

Although a systematic error in one of the two ${ }^{14} \mathrm{C}$ laboratories cannot be excluded (Table 1), re-deposition of old organic matter is the main reason to explain the discrepancy between our obtained ${ }^{14} \mathrm{C}$ dates. Most of the selected samples for dating were taken from silty and clayey sediments and were therefore likely derived from older material which was eroded by the different hydrological phases of Acre River. Such deposition of reworked material in oxbow lakes is a common process which has been previously reported by Räsänen et al. (1991). Based on the historical information derived from the expedition and map by William Chandless (1866), the lake did not exist in that time but has been an active meander.

Since our sediment record contains very fine-grained lacustrine deposits it must therefore be younger than 1866 AD. Additional evidence for a relatively young 
oxbow lake is the vicinity of the lake to the main active river channel (Fig. 5), causing high sedimentation rates similar to the Mamoré River in Bolivia as reported by Plotzki et al. (2013).

Anthropogenic influence has also a significant contribution of sediments (Fig. 5). A vast change in vegetation cover was detected in the peripheral area and inside of the lake (1984-2014), pointing to a probable new source of sediments into the lake.
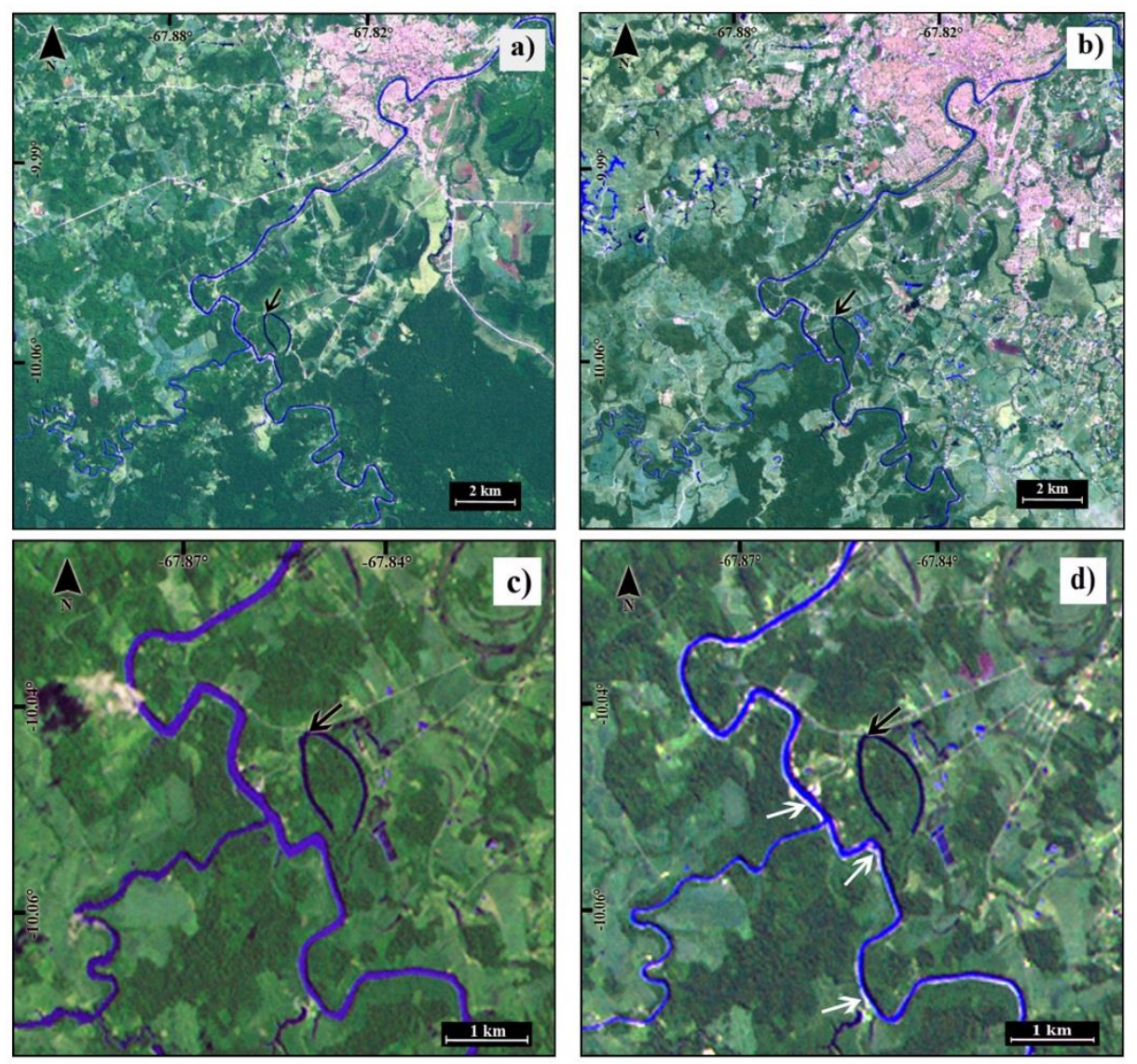

Fig. 5. Semi natural color images showing changes in vegetation cover in Rio Branco City and hydrological variability of Acre River derived from Landsat 5 shortwave infrared band 7, near infrared band 5 and green band 3; black arrow is showing the coring site. a) Image from Rio Branco City and Amapá Lake on July 1984. b) Image from Rio Branco City and Amapá Lake on July 2010. c) Image from Acre River and Lago Amapá at the end of the wet season on March 1996, showing high water levels in the main Acre River channel without visible riverbanks. d) Image from Acre River and Lago Amapá during the dry season on June 1996, displaying the reduction on the water level in the main channel detected by the presence of riverbanks (see white arrows). 


\subsubsection{XRF record}

The development and sediment dynamics of Lago Amapa during the last ca. 100 years are reflected in the XRF record. Ti and $\mathrm{Si}$ are typical elements indicating influx of terrigenous matter into the lake (Haug et al., 2001; Enters et al., 2010a). Lighter colored sediment layers with high Ti denote terrigenous input of eroded sediments during high stands of the Acre River in the wet season (Fig. 4). On the contrary dark layers and low values of Ti are deposited during the dry season (Lorente, 1990; Räsänen et al., 1991). These characteristics are reflected in different patterns along the core, with thicker light bands at the bottom part to thinner bands at the top, displaying a reduced influence of the river on Lago Amapá deposits (Table 2, Fig. 4).

The high correlation between $\mathrm{Si}$ and $\mathrm{Ti}$ shows that biogenic Si such as diatom frustules does not play a significant role in the sediment composition of Lago Amapá. The influence of Acre River decreases with time as shown by the decreasing trends $\mathrm{Ti}$ and $\mathrm{Si}$. These patterns point to a transformation towards a more isolated lake which is flooded by the river only during exceptional severe flood events. Likewise the rising inc/coh ratio shows that the sedimentation of organic matter gets dominating and that Lago Amapá shifts to a more productive state (Dean et al., 1993; Brunschön et al., 2010; Enters et al., 2010a, 2010b). During this process there is a change to more reduced conditions as shown by the decreasing Fe/Mn ratio which is caused by the decomposition of organic matter (Dean et al., 1993; Granina et al., 2004).

We interpret the variations in the Ca profile as changes of the sediment source. In older sediments high Ca counts reflect relatively unweathered terrigenous material from the Andes brought into Lago Amapá by the Acre River. The decrease in Ca in younger sediment units can be explained by a more local source of the terrigenous material, probably a consequence of human induced erosion of weathered soils in the surroundings of the lake. This is also partly reflected in the $\mathrm{Ti} / \mathrm{K}$ record. Assuming that $\mathrm{K}$ is mostly contained in clay minerals such as illite and $\mathrm{Ti}$ is dominantly found in silt-sized minerals such as rutile $\left(\mathrm{TiO}_{2}\right)$ the $\mathrm{Ti} / \mathrm{K}$ ratio can serve as a parameter for grain-size (Dean et al., 1993; Enters et al., 2010b). Higher $\mathrm{Ti} / \mathrm{K}$ ratios in the uppermost $50 \mathrm{~cm}$ therefore indicate that coarser grained terrigenous material became deposited in the lake, probably from a short distance. 
In the sediment record of Lago Amapá we found no evidence of human pollution. Typical elements such as $\mathrm{Pb}, \mathrm{Zn}, \mathrm{Hg}$ or $\mathrm{Cu}$ do not increase during the last 100 years.

\subsubsection{Pollen record}

High occurrence of pioneers and moderate swamp and floodplain and terra firme vegetation indicate early successional stages in the surroundings of the lake (Figs. 2 and 3). The origin of this process of colonization of species is due to the erosional and depositional activity of Acre River (Salo et al., 1986) for the period LA-I. In the period LA-IIa and LA-IIb these successional stages are reduced with an increase of pioneers, especially Cecropia, pointing to a high degree of vegetation change in the zone, which might be as a result of human influence (Figs. 2, 3 and 5). Low pollen concentration is associated to the high sedimentation rates at the bottom of the record LA-I.

\subsubsection{Early phase of Lago Amapá ( 1900 AD)}

During this period (zone LA-I) the presence of Andean pollen taxa indicate a frequent connection of Lago Amapá to the Acre River during flood events. Higher hydrological variability and low values in pollen concentration are related to the high sedimentation rates at that time (Figs. 2 and 3). The lake had good oxygenation. These suggestions are corroborated by $\mathrm{Ti}$ and $\mathrm{K}$ counts with the highest values of the record plus the thick light bands on the sediment, indicating more fluvial input and less accumulation of organic matter (low Fe/Mn and inc/coh ratios) (Fig. 4). Within these conditions Andean taxa were deposited into the cutoff channel coming from Peruvian Andean headwaters, indicating also a more regional signal. Even with a low pollen concentration in this zone, plant vegetation diversity was greater with a higher representation of taxa of swamp and floodplain forest like Moraceae/Urticaceae, Caesalpiniaceae and terra firme forest with Acalypha, Melastomataceae and Sapindaceae (Figs. 2 and 3).

Throughout the core, no direct pollen signal was found that could indicate human influence such as pollen grains of Zea mays or other agricultural crops used by the natives. However, the high percentages of pioneer taxa especially Cecropia, and the absence of charcoal indicate that changes in vegetation are not the result of slash and burning agriculture (Bush et al., 2007b), but instead the effect of the hydrology 
of the floodplain and its influence on the succession of the vegetation in the surroundings of Lago Amapá (Figs. 2 and 3). The main changes in vegetation during this period (Zone LA-I) are caused by the seasonality of the river rather than human impact, considering the fluvial dynamic as the main factor of transformation (Kalliola et al., 1991; Morais et al., 2008) and that the most clearly sequenced patterns of successional vegetation on lakes are encountered along meandering rivers (Toivonen et al., 2007).

\subsubsection{Human impact ( 1950-2009)}

During this second period of Lago Amapá record (Zone LA-IIa and LA-IIb) different disturbances can be detected. In the first stage of the second phase (Zone LA-IIa), the environmental conditions were not favorable to preserve pollen grains in the sediment resulting in the lowest pollen concentration rates of the record. Conditions should be favorable to pollen accumulation since detrital input is reduced, with low values of $\mathrm{Ti}, \mathrm{K}$, and $\mathrm{Fe} / \mathrm{Mn}$ ratio and an increase on lake productivity (inc/coh), but the rapid changes in the detrital input prevent a better accumulation (Figs. 3 and 4). The pollen spectra during this time are showing a high percentage of pioneer taxa and the reduction of different forest taxa. The increase in the frequency of the banding of the sediment from 144 to $114 \mathrm{~cm}$ and the absence of Andean taxa are pointing to a much reduced influence from Acre River. The very high occurrence of Cecropia and the reduction of the different forest types as Salix, Mabea, Rubiaceae and Caesalpinaceae (Parolin et al., 2002; Stevaux et al., 2013) are interpreted as a signal of the expansion of Rio Branco City. Furthermore the reduction on the counts of the normalized XRF elements and $\mathrm{Fe} / \mathrm{Mn}$ ratio indicates less hydrological variability in the lake (Fig. 4).

In the second phase of this period (Zone LA-IIb), the further increase of Cecropia and the appearance of other pioneer taxa (Trema, Asteraceae, Poaceae) can be interpreted as sign of strongly disturbed forests where clearance for cattle breeding and logging was practiced adjacent to the lake (see Bush and Colinvaux, 1988; Weng et al., 2002; Irion et al., 2006). This assumption is also consistent with the changes in the landscape in the region from the last 30 years. Landsat images and recent studies along Rio Branco City show rapid changes in vegetation cover along the year, mainly caused by extensive logging (Fig. 5) (Silva et al., 2008; Figueiredo, 2010). During this phase, pollen accumulation rises to the maximum of the record, 
and pollen diversity is the lowest (Fig. 3). A higher pollen accumulation and the increase on the pollen signal of pioneers are supported by the decline of Acre River influence (Ti, $\mathrm{K}$ and $\mathrm{Fe} / \mathrm{Mn}$ ) (Figs. 2-4). We hypothesize that in this period Lago Amapá was completely separated from the channel of Acre River and had only direct connection during exceptional high flood events.

Recent hydrological studies show that water levels in Acre River and Lago Amapá exhibit huge changes during the wet and dry seasons (Fig. 5) (Keppeler and Hardy, 2004a; Duarte, 2006; Silva et al., 2013). According to Keppeler and Hardy (2004a) the minimum and maximum water level of Lago Amapá is between 2.7 and $4.5 \mathrm{~m}$ during the dry and wet season respectively and there is a connection when the lake level exceeds $3.8 \mathrm{~m}$ during the high water period (Silva et al., 2013). In this sense, when oxbow lakes are separated from the main river channel during low water periods, it is expected that they are more susceptible to the influence of local processes (Carvalho et al., 2001) and this could be the reason why the lake is showing mainly the anthropogenic signals. In Lago Amapá, allogenic sediments are primarily derived from human disturbances. Those perturbations increase the amounts of nutrients and silt that enter the lake (Keppeler and Hardy, 2004b). This assumption corresponds to the normalized $\mathrm{Ca}$ and $\mathrm{Ti} / \mathrm{K}$ records with peaks that are interpreted as a change on the source of clastic input. From 80 to $70 \mathrm{~cm}$ huge peaks of $\mathrm{Ti} / \mathrm{K}$ ratio are showing an increase on the grain size of the sediments that is possibly associated with the erosion produced by the increase of logging, fisheries and road construction in the area (Figs. 4 and 5). Likewise, Cecropia has the highest abundance that is slightly reduced towards the top.

The history of Rio Branco is inherently bound to the rubber production during the 19th and 20th centuries which promoted a migration from Europeans and Northeastern natives from Brazil to Rio Branco City. Afterwards, the city was an important port and commercial factory site (Leite, 2007). The proximity of Lago Amapá to the city and its particular floodplain land form are displaying what could be a combination of human and river channel influence during the last ca. 100 years. 


\section{Conclusions}

Western Amazonian oxbow lakes contain different types of sediments coming from Andean headwaters and local Neogene and Quaternary deposits. Two distinct changes were detected by our multi-proxy analyses of the Lago Amapá deposits: (1) the reduction of the hydrological variability and (2) the increase of pioneer taxa towards the top of the pollen record. These changes are related to the origin of the lake from the meandering river system, as well as the increasing human influence on the vegetation as a result of the establishment and expansion of Río Branco City due to the rubber boom starting in the 19th century.

Our results show that more than one sediment core at a single study site is needed to understand the trends of vegetation succession in the Acre river floodplain due to the different sedimentation rates in oxbow lakes. Reliable ${ }^{14} \mathrm{C}$ dating of oxbow lake sediments is difficult as a result of the high amount of re-deposited organic material. Additionally, further studies on vegetation and pollen rain relationships are needed to understand the changes of vegetation succession in the Acre river floodplain.

Lago Amapá is sensitive to local and recent changes in vegetation and sediment deposition. Therefore this first approach to understand past floodplain dynamics in western Brazil shows mainly changes from the surroundings of the oxbow lake influenced by the seasonal variability and Rio Branco City expansion.

\section{Acknowledgements}

We would like to thank Edgardo Latrubesse for the geology and hydrology literature in western Amazon, and Suzette Flantua for the Landsat Images sources. Vera Markgraf and an anonymous reviewer are thanked for their comments on an earlier version of this paper. Special thanks to Sonia Fontana and Thomas Giesecke for their support and valuable discussions during this project phase and Camilo Saldaña for the English revision of the manuscript. The DAAD-COLFUTURO scholarship is thanked for funding the first author. The field trip was funded by the German Research Foundation (DFG project BE-2116/11-1). 


\section{References}

Behling, H., Hooghiemstra, H., 1997. Late Quaternary palaeoecology and palaeoclimatology from pollen records of the savannas of the Llanos Orientales in Colombia. Palaeogeography, Palaeoclimatology, Palaeoecology 139, 251-267.

Behling, H., Hooghiemstra, H., 1999. Environmental history of the Colombian Savannas of the Llanos Orientales since the Last Glacial Maximum from lake records El Pinal and Carimagua. Journal of Paleolimnology 21, 461-476.

Behling, H. and Costa, M.L., 2000. Holocene environmental changes from the Rio Curuá record in the Caxiuanã region, eastern Amazon Basin. Quaternary Research, 53, 369-377. doi:10.1006/qres.1999.2117.

Behling, H., Keim, G., Irion, G., Junk, W., Nunes de Mello, J., 2001. Holocene environmental changes inferred from Lago Calado in the Central Amazon Basin (Brazil). Palaeogeography, Palaeoclimatology, Palaeoecology 173, 87101.

Blaauw, M., 2010. Methods and code for 'classical' age-modelling of radiocarbon sequences. Quaternary Geochronology 5: 512-518. doi: 10.1016/j.quageo.2010.01.002.

Brunschön, C., Haberzettl, T., Behling, H., 2010. High-resolution studies on vegetation succession, hydrological variations, anthropogenic impact and genesis of a subrecent lake in southern Ecuador. Vegetation History and Archaeobotany 19, 191-206. doi: 10.1007/s00334-010-0236-4.

Burbridge, R.E., Mayle, F.E., Killeen, T.J., 2004. Fifty-thousand-year vegetation and climate history of Noel Kempff Mercado National Park, Bolivian Amazon. Quaternary Research 61, 215-230. doi :10.1016/j.yqres.2003.12.004.

Bush, M.B., Colinvaux, P.A., 1988. A 7000-year pollen record from the Amazon lowlands, Ecuador. Vegetation 76, 141-154.

Bush, M., Silman, M., de Toledo, M., Listopad, C., Gosling, W., Williams, C., de Oliveira, P., Krisel, C., 2007a. Holoce fire and occupation in Amazonia: 
records from two lake districts. Philosophical transactions of the royal Society B 362, 209-218. doi: 10.1098/rstb.2006.1980.

Bush, M.B., Silman,M.R., Listopad.,C.S., 2007b. A regional study of Holocene climate change and human occupation in Peruvian Amazonia. Journal of Biogeography 34, 1342-1356.b. doi : 10.1111/j.1365-2699.2007.01704.x.

Carreira, L.M.M., da Silva, M.F., Lopes, J.R.C., Nascimento, L.A.S., 1996. Catálogo de Pólen das Leguminosas da Amazônia Brasileira. Belém: Museu Paraense Emílio Goeldi, pp. 137.

Carvalho, P., Bini, L.M., Thomaz, S.M., Oliveira, L.G., Robertson, B., Tavechio, W.L.G., Darwisch, A.J., 2001. Comparative limnology of South American floodplain lakes and lagoons. Acta Scientiarum, Maringá 23, 265-273.

Chandless, W., 1866. Notes on the River Aquiry, the Principal affluent of the River Purûs. Journal of the Royal Geographical Society of London 36, 119-128.

Dean, W.E., 1993. Physical properties, mineralogy, and geochemistry of Holocene varved sediments from Elk Lake, Minnesota, in Bradbury, J.P, and Dean, W.E., (eds), Elk Lake, Minnesota: Evidence for Rapid Climate Change in the North-Central United States: Boulder, Colorado, Geological Society of America 276, 135-157.

Dickau, R., Bruno, M.C., Iriarte, J., Prümers, H., Jaimes Betancourt, C., Holst, I., Mayle, F., 2012. Diversity of cultivars and other plant resources used at habitation sites in the Llanos de Mojos, Beni, Bolivia: evidence from macrobotanical remains, starch grains, and phytoliths. Journal of Archaeological Science 39, 357-370. doi:10.1016/j.jas.2011.09.021.

Duarte, A.F., 2006. Aspectos da climatologia do Acre, Brasil, com base no interval 1971-2000. Revista Brasileira de Metereologia 21, 308-317.

Enters, D., Behling, H., Mayr, C., Dupont, L., Zolitschka, B., 2010a. Holocene environmental dynamics of south-eastern Brazil recorded in laminated sediments of Lago Aleixo. Journal of Paleolimnology 44, 265-277. doi:10.1007/s10933-009-9402-z. 
Enters, D., Kirilova, E., Lotter, A. F., Lücke, A., Parplies, J., Jahns, S., Zolitschka, B., 2010b. Climate change and human impact at Sacrower See (NE Germany) during the past 13,000 years: A geochemical record. Journal of Paleolimnology, 43(4), 719-737. doi.org/10.1007/s10933-009-9362-3

Erickson, C.L., 2008. Amazonia: the historical ecology of a domesticated landscape. Silverman, H. \& Isbell, W. (eds): Handbook of South American Archaeology. New York: Springer 157-183.

Erickson, C.L., 2010. The transformation of environment into landscape: the historical ecology of monumental earthwork construction in the Bolivian Amazon. Diversity 2, 618-652. doi:10.3390/d2040619.

Faegri, K., Iversen, J., 1989. Textbook of pollen Analysis.4th ed. Wiley, New York, pp.338.

Figueiredo, S.M.M., 2010. Avaliação da dinámica do desmatamento em Rio Branco, Acre, no periodo de 2007 a 2009. Programa de Zoneamento Econômico, Ambiental, Social e Cultural de Rio Branco-AC (ZEAS), pp.47.

Granina, L., Müller, B.,Wehrli, B., 2004. Origin and dynamics of Fe and Mn sedimentary layers in Lake Baikal. Chemical Geology 205, 55-72. doi:10.1016/j.chemgeo.2003.12.018

Grimm, E.C., 1987.CONISS: a fortran 77 program for stratigraphically constrained cluster analysis by the method of the incremental sum of squares. Computer and Geosciences 13, 13-35.

Grimm, E.C., 2011. Tilia/TGView 1.7.16. Illinois State Museum, Research and Collections Center.

Haug, H.G., Hughen, K.A., Sigman, D.M., Peterson, L.C., Röhl, U., 2001. Southward Migration of the Intertropical Convergence Zone Through the Holocene. Science 293, 1304-1307.

Hua, Q., Barbetti, M., Rakowski, A.Z., 2013. Atmospheric radiocarbon for the period 1950-2010. Radiocarbon 55, 2059-2072. doi:10.2458/azu_js_rc.v55i2.16177 
INMET, 2014. Instituto Nacional de Metereologia, Monitoramento das Estações Convencionais Ministério da Agricultura, Pecuária e Abastecimento. http://www.inmet.gov.br.

INPE, 2014. Instituto Nacional de Pesquisas Espaciais, Ministério da Ciencia, Tecnologia e Inovação. http://www.inpe.br.

Irion, G., Bush, M.B., Nunes de Mello, J.A., Stüben, D., Neumann, T., Müller, G., Morais, J.O., Junk, J.W., 2006. A multiproxy palaeoecological record of Holocene lake sediments from the Rio Tapajós, eastern Amazonia. Palaeogeography, Palaeoclimatology, Palaeoecology 240, 523-535. doi:10.1016/j.palaeo.2006.03.005.

Ishii, R.A., 2011. Viagens do "homem que virou rio": narrativas, traduções e percursos de William Chandless, pelas Amazônias, no século XIX. Universidade Federal do Acre, Brazil. Master Thesis.

Junk, W.J., Piedade, M.T.F., 2010. An Introduction to South American Wetland Forests: Distribution, Definitions and General Characterization. Junk, W.J., Piedade, M.T.F., Wittmann, F., Schöngart, J., Parolin, P. (eds). Amazonian floodplain forests: Ecophysiology, Biodiversity and Sustainable Management. New York: Springer 3-25.

Kalliola, R., Salo, J., Puhakka, M., Rajasilta, M., 1991. New site formation and colonizing vegetation in primary succession on the western amazon floodplains. Journal of Ecology 79, 877-901.

Kalliola, R., Salo, J., Puhakka, M., Rajasilta, M., 1992. Upper Amazon channel migration. Implications for vegetation perturbance and succession using bitemporal landsat MSS images. Naturwissenschaften 79, 75-79.

Keppeler, E.C., Hardy, E.R., 2004a. Vertical distribution of zooplankton in the water column of Lago Amapá, Rio Branco, Acre, Brazil. Revista Brasileira de Zoologia 21(2), 169-177.

Keppeler, E.C., Hardy, E.R., 2004b. Abundance and composition of rotifer in an abandoned meander lake (Lago Amapá) in Rio Branco, Acre, Brazil. Revista Brasileira de Zoologia 21(2), 233-241. 
Lani, J.L., Gomes, M.A., Pereira, N.W., 2008.Tipologias florestais do município de Rio Branco-AC. Boletim Técnico 15, p.54. Programa de Zoneamento Econômico, Ambiental, Social e Cultural de Rio Branco-AC (ZEAS), pp.56.

Latrubesse, E.M., Kalicki, T., 2002. Late Quaternary palaeohydrological changes in the upper Purus basin, southwestern Amazonia, Brazil. Zeitschrift für Geomorphologie. Supplementband 129, 41-59.

Latrubesse, E.M., 2012. Amazon Lakes. Lakes and reservoirs. Bengtsson, L., Herschy, R. and Fairbridge, R. (eds). Springer Verlag, 13-26.

Leite, A.P., 2007. De seringal a capital: a evolução urbana de Rio Branco-Acre no período dos ciclos da borracha do século XIX e XX. Universidade do Estado de Santa Catarina, Brazil. Bachelor Thesis.

Lombardo, U., Canal-Beeby, E., Veit, H., 2011. Eco-archaeological regions in the Bolivian Amazon: an overview of pre-Columbian earthworks linking them to their environmental settings. Geographica Helvetica 66, 173-182.

Lombardo,U., Denier, S., May, J-H., Rodrigues, L., Veit, H., 2013. Humanenvironment interactions in pre-Columbian Amazonia: the case of the Llanos de Moxos, Bolivia. Quaternary International 312, 109-119. doi:10.1016/j.quaint.2013.01.007.

Lorente, M.A., 1990. Textural characteristics of organinc matter in several subenvironments of the Orinoco Upper Delta. Geologie en Mijnbouw 69, 263-278.

Mayle, F.E., Beerling, D.J., 2004. Late Quaternary changes in Amazonian ecosystems and their implications for global carbon cycling. Palaeogeography, Palaeoclimatology, Palaeoecology 214, 11-25. doi:10.1016/j.palaeo.2004.06.016.

Mayle, F.E., Langstroth, R.P., Fisher,R.A., Meir, P.,2007. Long-term forest-savannah dynamics in the Bolivian Amazon: implications for conservation. Philosophical transactions of the royal Society B 362, 291-307. doi:10.1098/rstb.2006.1987. 
Morais, R.P., Aquino, S., Latrubesse, E.M., 2008.Controles hidrogeomorfológicos nas unidades vegetacionais da planície aluvial do rio Araguaia, Brasil. Acta Sci. Biol. Sci. Maringá 30, n. 4, 411-421. doi: 10.4025/actascibiolsci.v30i4.5871.

Parolin, P., Oliveira, A.C., Piedade, M.T.F., Wittmann, F., Junk, W.J., 2002. Pioneer trees in Amazonian floodplains: Three key specie form monospecific stands in different habitats. Folia Geobotanica 37, 225-238.

Pärssinen, M., Schaan, D., Ranzi, A., 2009.Pre-Columbian geometric earthworks in the upper Purús: a complex society in western Amazonia. Antiquity 83, 1084-1095.

Plotzki,A., May, J.H.,Preusser, F., Veit, H., 2013. Geomorphological and sedimentary evidence for late Pleistocene to Holocene hydrological change along the Río Mamoré, Bolivian Amazon. Journal of South American Earth Sciences 47, 230-242. doi:10.1016/j.jsames.2013.08.003.

Puhakka, M., Kalliola, R., Rajasilta, M., Salo, J., 1992. River types, site evolution and successional vegetation patterns in Peruvian Amazonia. Journal of Biogeography 19, 651-665.

Räsänen, M.E., Salo, J.S., Jungner, H., 1991. Holocene floodplain lake sediments in the Amazon: $14 \mathrm{C}$ dating and palaeoecological use. Quaternary Science reviews 10, 363-372.

Reimer, P.J., Bard, E., Bayliss, A., Beck, J.W., Blackwell, P.G., Bronk Ramsey, C., Buck, C.E., Edwards, R.L., Friedrich, M., Grootes, P.M., Guilderson, T.P., Haflidason, H., Hajdas, I., Hatté, C., Heaton, T.J., Hoffmann, D.L., Hogg, A.G., Hughen, K.A., Kaiser, K.F., Kromer, B., Manning, S.W., Niu, M., Reimer, R.W., Richards, D.A., Scott, E.M., Southon, J.R., Turney, C.S.M., van der Plicht, J., 2013. IntCal13 and Marine13 radiocarbon age calibration curves, 0-50,000 years cal BP. Radiocarbon 55, 1869-1887

R Development Core Team, 2015. R: A language and environment for statistical computing. R Foundation for Statistical Computing, Vienna, Austria. ISBN 3-900051-07-0, URL http://www.R-project.org. 
Roubik, D.W., Moreno, E., 1991. Pollen and Spores of Barro Colorado Island. Monographs in Systematic Botany, v.36, Missouri Botanical Garden.

Salo, J., Kalliola, R., Häkkinen, I., Mäkinen, Y., Niemelä, P., Puhakka, M., Coley, P.D., 1986.River dynamics and the diversity of Amazon lowland forest. Nature 322, 254-258.

Saunaluoma, S., Schaan, D., 2012. Monumentality in Western Amazonian formative societies: geometric ditched enclosures in the Brazilian state of Acre. Antiqua 2, e1. doi:10.4081/antiqua.2012.e1.

Schaan, D., Pärssinen, M., Ranzi, A., Piccoli, J.C., 2007. Geoglifos da amazônia ocidental: evidência de complexidade social entre povos da terra firme. Revista de Arqueologia 20, 67-82.

Silva, S.S.,Valentim, J.F., Amaral, E.F, Melo, A.W.F., 2008. Dinâmica do desmatamento no municipio de Rio Branco. Boletim Técnico 3, p.48. Programa de Zoneamento Econômico, Ambiental, Social e Cultural de Rio Branco-AC (ZEAS), pp.48.

Silva, M.T., Pereira, J.O., Vieira, L.J.S. and Petry, A.C. 2013. Hydrological seasonality of the river affecting fish community structure of oxbow lakes: A limnological approach on the Amapá Lake, southwestern Amazon. Limnologica 43, 79-90. doi: http://dx.doi.org/10.1016/j.limno.2012.05.002

Stevaux, J.C., Latrubesse, E.M., P.Hermann, M.L., Aquino, S., 2010. Floods in urban áreas of Brazil. Developments in Earth Surface Processes 13, 245-266.

Stevaux, J.C., Corradini, F.A., Aquino, S., 2013. Connectivity processes and riparian vegetation of the upper Paraná River, Brazil. Journal of South American Earth Sciences 46, 113-121. doi:10.1016/j.jsames.2011.12.007.

Stockmarr, 1971.Tablets with spores used in absolute pollen analysis. Pollen et Spores 13, 615-621.

Toivonen, T., Mäki, S., Kalliola, R., 2007. The riverscape of Western Amazonia-a quantitative approach to the fluvial biogeography of the region. Journal of Biogeography 34, 1374-1387. doi:10.1111/j.1365-2699.2007.01741.x. 
Weng, C., Bush, M.B., Athens, J.S., 2002. Holocene climate change and hydrarch succession in lowland Amazonian Ecuador. Review of Palaeobotany and Palynology 120, 73-90.

Wójcicki, K.J., 2006. The oxbow sedimentary subenvironment: its value in palaeogeographical studies as illustrated by selected fluvial systems in the Upper Odra catchment, southern Poland. The Holocene 16, 589-603. doi: 10.1191/0959683606hl953rp. 
Chapter 2 -Lago Amapá- 


\section{CHAPTER 3}

\section{Mid-Holocene vegetation dynamics with an early expansion of Mauritia flexuosa palm trees inferred from the Serra do Tepequém in the savannas of Roraima State in Amazonia, northwestern Brazil.}

Paula A. Rodríguez-Zorro', Marcondes Lima da Costa ${ }^{2}$, Hermann Behling ${ }^{1}$

1 Georg-August-University of Göttingen, Albrecht-von-Haller Institute for Plant Sciences. Department of Palynology and Climate Dynamics, Untere Karspüle 2, 37073 Göttingen, Germany, e-mail: paula.rodriguez@biologie.uni-goettingen.de

2 Universidade Federal do Pará (UFPA), Instituto de Geociencias, Av. Augusto Correa 1, Guamá, 66075-110 Belém, Brazil

Accepted in the Journal of Vegetation History and Archaeobotany 


\section{Abstract}

Transition zones between forest and savanna in northern South America are important areas for improving our understanding of ecosystem dynamics and climate change. The uniquely available mid-Holocene sediment deposits from the Serra do Tepequém plateau in Roraima State, northwestern Brazil, were used to analyze past forest-savanna dynamics through pollen, spores, microcharcoal and loss on ignition (LOI). In this newly studied landscape, two distinct periods of vegetation, fire and climate dynamics have been recorded. The first phase from ca. 7,570 to 6,190 cal BP, with the dominance of savanna vegetation in particular with Poaceae and Cyperaceae and some small forest patches with Moraceae/Urticaceae, Alchornea and Schefflera, indicates a relatively dry period. Based on the microcharcoal concentration and influx data, frequent regional fires occurred at that time. The second phase from ca. 6,190 to 4,900 cal BP shows a change in the vegetation composition with an increase of Ilex, Schefflera and Fabaceae. In this period forest expanded, while savanna became reduced, reflecting an increase of wetter conditions. The fire frequency was markedly lower. The first occurrence of Mauritia flexuosa palm was at ca. 7,300 cal BP and an early expansion occurred at around 6,600 cal BP. This early expansion of M. flexuosa showed a development that was in opposition to the increase of fire and savanna expansion found in other regions in northern South America. The increase of wetter conditions in Serra do Tepequém in the mid-Holocene confirms other results found in savannas of Colombia and Venezuela between 7,000 and 6,600 cal BP.

Keywords Mauritia, Brazil, Forest-savanna mosaics, Fire, Climate change, Organic matter, Bayesian age depth modeling, Bacon 


\section{Introduction}

Palaeoecological reconstructions are important for understanding ecosystems and environmental dynamics and furthermore for projecting future climatic scenarios. However, despite the importance of preserving and understanding the Amazonian ecosystems, the number of palaeoecological records is still low (Flantua et al. 2015). Transition zones, such as forest-savanna mosaics, are of particular interest for palaeoclimatic reconstructions, as they are sensitive to disturbances and climatic changes during the past. Examples of such particular areas come from the savannas of northern South America (Hooghiemstra and Berrio 2007; Toledo and Bush 2009; Rull and Montoya 2014). In the Llanos Orientales in Colombia, the Gran Sabana in Venezuela and the Roraima savannas in Brazil different changes were detected in vegetation composition through the Holocene, with similar trends of changes to wetter conditions toward recent times. The forest-savanna mosaics have changed due to the action of climate and/or fires, forming different vegetation types of rainforests, shrub lands, and savannas (Montoya et al. 2011a; Rull et al. 2013). In most of the studied records in the area, a regional increase in wetter conditions for the mid-Holocene was detected due to a northernmost position of the Intertropical Convergence Zone (ITCZ) as was reported in several speleothem and geochemical records (Haug et al. 2001; Cheng et al. 2013; Bustamante et al. 2016). As a result, forest vegetation expanded in such savannas (Behling and Hooghiemstra 1999; Toledo and Bush 2009; Rull and Montoya 2014). A further increase in wetter conditions has also been detected for the late Holocene, in which strong human disturbances played a role (Behling and Hooghiemstra 1998, 1999; Meneses et al. 2013; Rull and Montoya 2014).

In the Gran Sabana in Venezuela, the interaction between savanna and forest in the Holocene was characterized by a marked increase of Mauritia flexuosa palm, in particular during the last 2,000 years (Montoya and Rull 2011; Rull et al. 2013; Ballesteros et al. 2014). The increase of $M$. flexuosa is interpreted as an indicator of wet environments, since it develops on diverse habitats with common geological and soil characteristics such as anoxic clay or sandy soils, poorly drained and frequent flooded areas, abundant organic material and high water tables (Lasso et al. 2013; Rull and Montoya 2014; Galeano et al. 2015). In addition, the interplay of fire and climate effects on vegetation during the last ca. 2,000 years has been 
dominated by fires, consequently promoting a continuous trend of savanna expansion, mostly driven by human disturbances (Rull et al. 2013). Similar findings for the late Holocene were reported in the Roraima savannas by Meneses et al. (2013), in which M. flexuosa stands have been present together with the expansion of savanna and high signals of fire. Similarly, an expansion of M. flexuosa was found in the savannas of Llanos Orientales in Colombia (Behling and Hooghiemstra 1999, 2000). M. flexuosa started to expand from ca. 4,000 uncal BP $(4,400 \mathrm{cal} \mathrm{BP})$, indicating wet environments that in the late Holocene were highly influenced by humans.

Despite of the effort on the palaeoecological reconstructions for the Gran Sabana and Llanos Orientales, there are only few records from the Brazilian Roraima savannas that studied the past forest-savanna dynamics and even fewer studying the role of fires and human occupation throughout the Holocene (Absy 1979; Desjardins 1996; Reis et al. 2008; Toledo and Bush 2009; Simões Filho et al. 2010; Meneses et al. 2013). The Roraima savannas in northwestern Brazil, which occur in the border area of Guyana and Venezuela, are of particular interest for reconstruction of past vegetation and climate changes. They are part of the "Rio Branco-Rupununi" complex with an area of ca. 61,664 km2 (Barbosa et al. 2007). This huge area is characterized by particular geomorphological features dominated by a set of dissected plateaus surrounded by intramontane pediplains, including several residual terrains across the extensive plain areas (Barni et al. 2015). The vegetation is mainly composed of a variety of grasses and sedges surrounded by drainage networks, which are covered by patches of gallery forest usually dominated by stands of M. flexuosa palms (known as "Buritizais") (Miranda and Absy 2000; Miranda et al. 2002; Barbosa and Miranda 2004).

Considering that there are few palaeoecological records describing the past vegetation and climate dynamics for the Roraima savannas in Brazil we have selected the plateau of Serra do Tepequém, also known as the "Brazilian tepui" where forest-savanna mosaics and M. flexuosa occur. We aimed to study forestsavanna dynamics in a new landscape with a uniquely available sedimentary sequence to contribute to the research on vegetation history and possible human impact in an area of interest for archaeology using pollen, spore, microcharcoal and loss on ignition (LOI) analyses. Our study focuses on detecting a regional 
increase in wetter conditions for the mid-Holocene using forest-savanna interactions, with an early increase of the palm M. flexuosa. We have used the development of this palm and its relation to the fire and savanna dynamics as indicators of wet environments. Furthermore, we compared our new findings with results from other savanna ecosystems such as the Gran Sabana and Llanos Orientales in northwestern South America to detect any similarities or differences.

\section{Study Area}

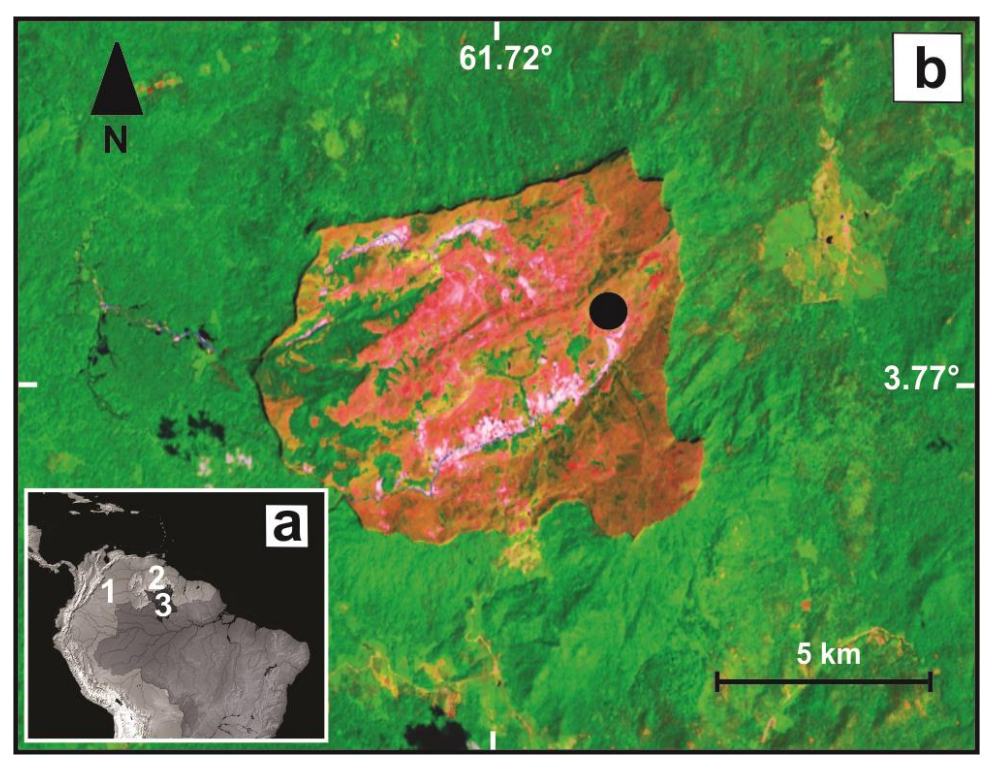

Fig.1 Location of the Serra do Tepequém sediment core. a) Location of palaeoecological studies in Savannas of Northern South America: 1) Llanos Orientales-Colombia, 2) Gran Sabana-Venezuela and 3) Roraima savannas-Brazil. b) False color image of Serra do Tepequém sediment core. The image is composed by mid-infrared band 5, near infrared band 4 and the green band 3 courtesy of the U.S. Geological Survey (USGS 2014). Black circle shows the location of the sediment record of Serra do Tepequém. White to pinkish areas reflect the exposed soils due to the mining activities in the plateau

Serra do Tepequém belongs to Roraima State in northwestern Brazil (Fig. 1). The sediment core was collected on the plateau in an exposed soil profile $\left(3^{\circ} 47^{\prime} 31.24^{\prime \prime} \mathrm{N}\right.$ $61^{\circ} 42^{\prime} 15.59^{\prime \prime E}$, elevation $\left.635 \mathrm{~m}\right)$, which is close $(100 \mathrm{~m})$ to a spring area that has been influenced by diamond mining during the last decades and more recently by a small riverine formation. A huge area of the upland has been strongly influenced by diamond mining in the last decades (Brasil 1975; Beserra Neta et al. 2015) (Fig. 
2c). The plateau possesses a range of elevations, reaching up to $1,100 \mathrm{~m}$ a.s.l. above valleys with altitudes of between 500 to $600 \mathrm{~m}$, interrupted by hills and mountains varying from 650 to $900 \mathrm{~m}$ up to 1,100 $\mathrm{m}$ in height (Nascimento et al. 2012; Beserra Neta et al. 2015). The geomorphology of the area is characterized mainly by erosive scarps, steep slopes, valleys and residual mountains. Geologically this plateau is an erosional remnant of the Roraima formation (Brasil 1975; Almeida-Filho and Shimabukuro 2002), containing mainly sandstones, conglomerates, and minor occurrences of siltstone and claystone, lying over acid to intermediate Early Proterozoic volcanites (rhyolites, rhyodacites, andesites, etc.) of the Surumu Group (Almeida-Filho and Shimabukuro 2002). The climate in the region (based on the only state-run station, which is located in the capital city Boa Vista) is tropical wet and dry (AWi, after the Köppen classification) (Miranda et al. 2002; Barbosa and Miranda 2004). The mean annual temperature and precipitation are $28{ }^{\circ} \mathrm{C}$ and 1,600 mm, respectively (Barbosa and Miranda 2004). The dry season covers the period from October to March with the driest phase in December and March. The wet season occurs from April to September with the wettest phase in May and August (INMET 2015).

The vegetation in the surroundings and on the slopes of the plateau is characterized by tropical rain forest. On the plateau itself the vegetation is mainly composed of grasses with some shrubs, from open grass savannas on the plains to arboreal savannas in the valleys (Nascimento et al. 2012; Beserra Neta et al. 2015). Due to its particular features, the vegetation of the Serra do Tepequém coring site can be classified, as proposed by Barbosa and Miranda (2004), as different savanna types growing along valleys, slopes and on gravel to sandy soils. The main vegetation cover is dominated by grasses from the genera Andropogon and Trachypogon, and Cyperaceae. Trees from the genera Aspidosperma, Tabebuia, Mimosa, Piptadenia and Cassia are usually growing in the area. Small patches of $M$. flexuosa palm are found in some areas of the plateau. 


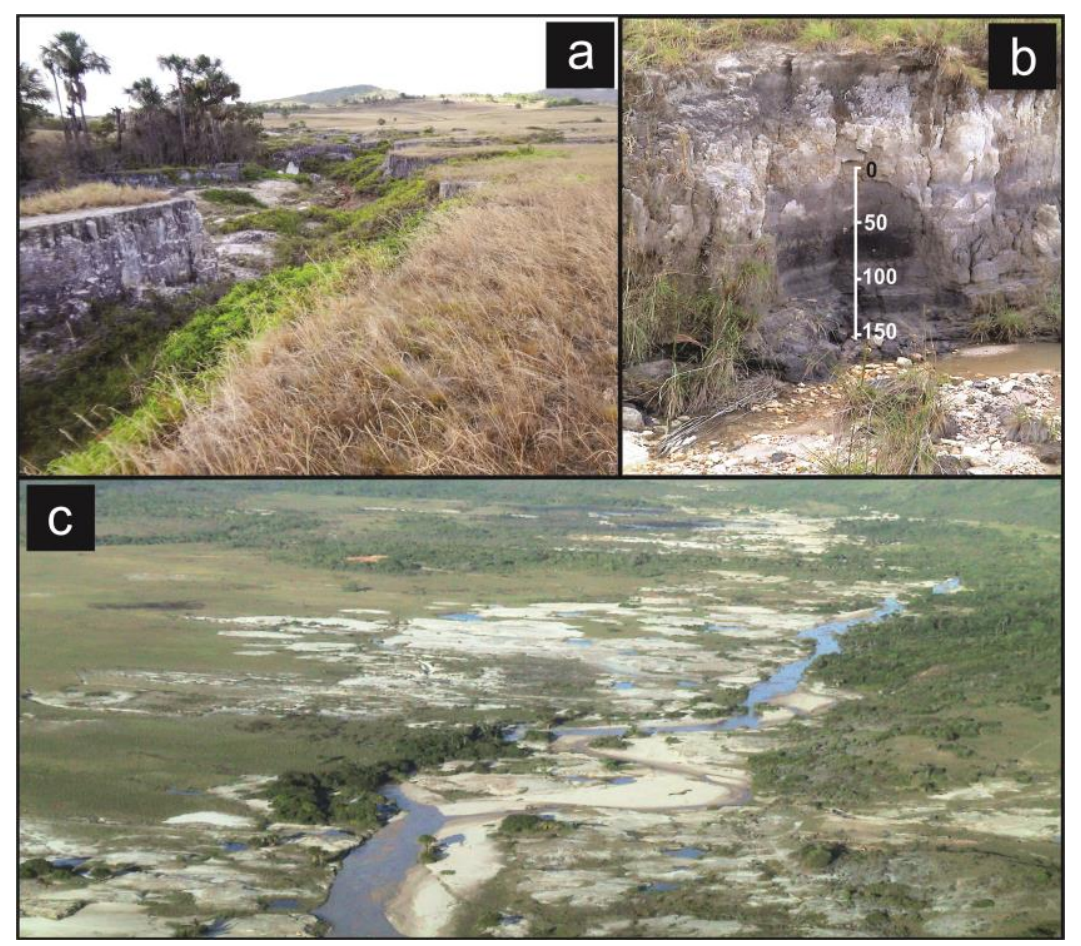

Fig. 2 Serra do Tepequém coring site and human impact in the Plateau. a) Main vegetation growing in the coring area: M. flexuosa stands, ferns and grasslands. b) Coring site, showing the location and scale of the sampled sediments. From 150 to $200 \mathrm{~cm}$, sediments were recovered with a Russian corer following the continuity of the profile. c) Mining activities located $3 \mathrm{~km}$ to the south-west from the coring site. Open and washed soils, disturbed vegetation and artificial channels are observed due to the water pressure used to collect gold and diamonds.

\section{Material and Methods}

The $200 \mathrm{~cm}$ long continuous sediment core from Serra do Tepequém was recovered in 2004 from an exposed wall in a spring area using $50 \mathrm{~cm}$ long split PVC tubes for the first $150 \mathrm{~cm}$ of the profile (Fig. 2b). At the same place, directly below the first $150 \mathrm{~cm}$ of the core, a Russian corer was used to obtain the sediments from 150 to $200 \mathrm{~cm}$, which were not exposed. Deposited material above $0 \mathrm{~cm}$ (see Fig. 2b) was clearly reworked, probably due to mining activities in the area and was not recovered. The core was stored in the laboratory under cold $\left(4^{\circ} \mathrm{C}\right)$ and dark conditions. For palynological analysis, 31 subsamples $\left(0.5 \mathrm{~cm}^{3}\right)$ were taken at $5 \mathrm{~cm}$ intervals along the core. As a result of the mining activities in the area, the first 50 $\mathrm{cm}$ of the record are clearly disturbed and reworked, besides which the pollen content was almost zero. Therefore the core was analyzed from 50 to $200 \mathrm{~cm}$ depth since our focus for palaeoecological reconstruction was mainly pollen and 
microcharcoal analysis. Pollen samples were prepared using standard pollen preparation techniques (Fægri and Iversen 1989). One tablet of exotic marker (Lycopodium clavatum) was added per sample for the calculation of pollen concentration and influx (Stockmarr 1971). Most of the samples were counted to a sum higher than 300 pollen grains. Spores were excluded from the pollen sum.

Pollen and spore identification was based on reference literature (Roubik and Moreno 1991; Carreira et al. 1996; Rangel-Ch et al. 2001; Rull 2003; López-Martínez et al. 2010; Leal et al. 2011; Montoya et al. 2012) and the pollen reference collection at the Department of Palynology and Climate Dynamics (University of Göttingen, Germany). The grouping of the pollen taxa into the ecological groups was been done according to Marchant et al. (2002), Leal et al. (2013) and the Brazilian flora checklist (REFLORA 2015). The zonation of the pollen diagram was obtained using the method of optimal splitting by sums of squares, using the pollen and pollenspores data to detect differences. The number of statistically significant zones was evaluated using the broken stick model (Bennett 1996). All illustrations and calculations were done with Psimpoll (Bennett 2009). Pollen based indices were calculated using the program $R$ version 3.2.0 ( $R$ development core team 2015) and the vegan package version 2.3.0 (Oksanen et al. 2015). Pollen-spores sample diversity was plotted based on rarefaction analysis to a base of 10 counts (E(T10)) and pollen-spores richness using rarefaction to a base of 400 counts (E(T400)) according to Matthias et al. (2015).

Microcharcoal particles (from $10 \mu \mathrm{m}$ up to $150 \mu \mathrm{m}$ ) were counted on the pollen slides without differentiation and expressed as concentration (particles $/ \mathrm{cm}^{3}$ ) and influx (particles $/ \mathrm{cm}^{2} / \mathrm{yr}$ ). LOI analysis was done according to Heiri et al. (2001). Subsampling was carried out each $\mathrm{cm}$ along the core to calculate the organic matter content (LOI $\left.550^{\circ} \mathrm{C}\right)$.

For radiocarbon dating, six samples were submitted to the AMS NTUAMS Laboratory of the National University of Taiwan (Table 1). Radiocarbon dates were calibrated with the curve IntCal13 for the northern hemisphere (Reimer et al. 2013). Calibration and age depth model were performed with $\mathrm{R}$ ( $\mathrm{R}$ development Core Team 2015). The age-depth model was constructed using Bayesian statistics with the package Bacon (Blaauw and Christen 2011), which reconstructs accumulation 
histories for sediment deposits and helps to identify outliers in the data. All radiocarbon dates were included for the analysis. The accumulation rate prior was set as a gamma distribution with a mean of $20 \mathrm{yr} / \mathrm{cm}$ and shape of 2 and beta distribution with strength of 4 and mean of 7.31 sections were used (each $5 \mathrm{~cm}$ ) for the age-depth model. The core segment $(68$ to $50 \mathrm{~cm}$ ) above the dated lower core section was calculated by the software by extrapolation.

Landsat 7 imaging for the study area map was obtained from the earth explorer web page of the U.S. Geological Survey (USGS 2014). This false color elevation image is composed of the shortwave mid-infrared band 5, near-infrared band 4 and the red band 3. The image thus composed was used to show land-water boundaries.

\section{Results}

\subsubsection{Stratigraphy and Chronology}

The sediments of the Serra do Tepequém core are mainly composed of grey-brown to black organic clay and sandy deposits (Table 2). Thin layers of charcoal mixed with sand are found along the core and are more frequent between 130 and $70 \mathrm{~cm}$. The organic matter content (LOI $550{ }^{\circ} \mathrm{C}$ ) increases from the bottom to the top reaching values up to $18 \%$. Higher values are found between 100 to $70 \mathrm{~cm}$ and the lowest at the bottom and top of the core (at 200 and $50 \mathrm{~cm}$ ). Detailed inspection of the core after fieldwork indicated that the upper core part $(50-0 \mathrm{~cm})$ has been reworked (Fig. 2b). In some parts between 50 and $0 \mathrm{~cm}$, sediments are very compact with a high amount of gravel (ca. $0.5 \mathrm{~cm}$ diameter), in other sections they are fragmented without obvious stratigraphy. The LOI values for this section are between of 3-5 \% (ESM - Online Resource 1).

A total of six AMS 14C dates was obtained from bulk sediment (Table 1). The age at $74 \mathrm{~cm}$ gave the oldest age of the set of samples making it clearly an outlier, probably due to reworked material that was included in the bulk sediment for radiocarbon analysis. The other dates span between 7,140 and 4,950 cal BP. Three dates from the middle of the sequence (at 144, 122 and $102 \mathrm{~cm}$ ) are not in stratigraphic order. 
Table 1 List of the AMS radiocarbon dates from the Serra do Tepequém core

\begin{tabular}{lllll}
\hline $\begin{array}{l}\text { Depth } \\
(\mathbf{c m})\end{array}$ & Lab code & Dated Material & ${ }^{14}$ C yr BP & $\begin{array}{l}\text { Age cal BP(weighted } \\
\text { average, 2 } \mathbf{~})\end{array}$ \\
\hline 68 & NTUAMS-1770 & Bulk sediment & $4534 \pm 39$ & $4848-5065$ \\
$74^{*}$ & NTUAMS-573 & Bulk sediment & $6981 \pm 25$ & $7357-7472$ \\
102 & NTUAMS-716 & Bulk sediment & $5443 \pm 19$ & $5906-5942$ \\
122 & NTUAMS-717 & Bulk sediment & $6019 \pm 21$ & $6458-6569$ \\
$144^{*}$ & NTUAMS-774 & Bulk sediment & $5018 \pm 48$ & $5372-5601$ \\
200 & NTUAMS-718 & Bulk sediment & $6625 \pm 23$ & $7093-7190$ \\
\hline
\end{tabular}

*dates rejected for age depth modeling

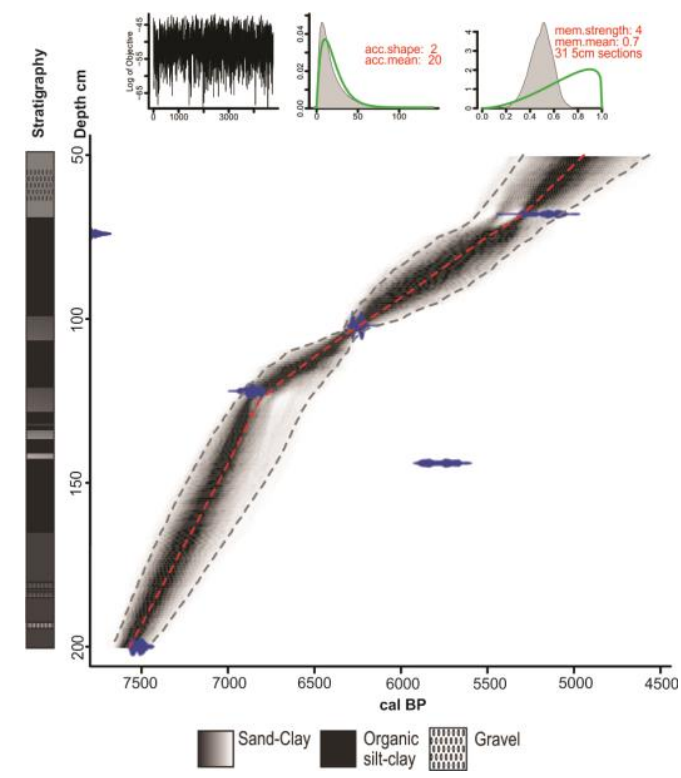

Fig. 3 Stratigraphy and chronology for the Serra do Tepequém sediment core. The stratigraphy is shown on the left side. Upper panel shows 3 graphs: (left) the Markov Chain Monte Carlo iterations for the Bayesian Bacon model; (middle) prior (gray line) and posteriori (filled gray curve) distributions for the accumulation rate; and (right) prior and posterior distributions of the memory. The lower panel shows the calibrated distribution of the radiocarbon dates and the age-depth model (darker greys indicates the likelihood; grey stippled lines show 95\% confidence intervals; white dashed curve shows single 'best' model based on the weighted mean age for each depth (Blaauw and Christen 2011). 
These dates allow two possible alternative age depth relationships. First, building the model with the date at $144 \mathrm{~cm}$ and rejecting the two dates at 122 and $102 \mathrm{~cm}$ as too old, or second, rejecting the date at $144 \mathrm{~cm}$ as too young. Although the presence of too old dates is conceptually easier to understand, ages that are too young may occur due to roots or fungal and bacterial growth (Wohlfarth et al. 1998). As there is no other indication whether one date is more reliable than the other, we favor the more parsimonious solution of rejecting the date at $144 \mathrm{~cm}$ as being too young to be included in our model. Furthermore, keeping the dates at 122 and $102 \mathrm{~cm}$ brings them onto a near linear trend with the uppermost date at 68 $\mathrm{cm}$ adding confidence to this choice. Regardless of these conceptual considerations we have used the Bayesian age-depth modeling routine Bacon with all the radiocarbon dates, since it has outlier detection capabilities (Blaauw and Christen 2011). Running Bacon without any previous assignment of outlier probability of certain dates, we obtained the age model that we would have favored conceptually, with the dates at 144 and $74 \mathrm{~cm}$ detected as outliers and therefore not considered in the final age depth model (Fig. 3).

The Bayesian model provided ages spanning from 7,570 to 4,900 cal BP (200 to 50 $\mathrm{cm}$ core depth), comprising part of the mid-Holocene. The resulting time resolution between the analyzed samples is between 100 to 300 years.

On the other hand, caution should be taken when interpreting the ages from 68 to $50 \mathrm{~cm}$, since they are extrapolated and might reflect different deposition times as shown by the stratigraphy and LOI changes (Table 2, Fig. 5). 
Table 2. Description of the sediments from the Serra do Tepequém core

\begin{tabular}{|c|c|}
\hline Core depth $(\mathrm{cm})$ & Description of Sediments \\
\hline $0-50$ & $\begin{array}{l}\text { Light brown sandy to silty reworked sediments with gravel } \\
\text { and roots from grasses }\end{array}$ \\
\hline $50-70$ & $\begin{array}{l}\text { Dark grey sandy to silty sediments with some fractions of } \\
\text { gravel }\end{array}$ \\
\hline $70-115$ & $\begin{array}{l}\text { Black organic clay sediments mixed with charcoal and some } \\
\text { sandy layers }\end{array}$ \\
\hline $115-130$ & $\begin{array}{l}\text { Layered sandy sediments alternating with bands of black } \\
\text { organic clay and charcoal }\end{array}$ \\
\hline $130-143$ & $\begin{array}{l}\text { Clay to silty sediment mixed with a small proportion of fine } \\
\text { yellowish sand }\end{array}$ \\
\hline $143-168$ & Dark gray organic clay to silty sediments with charcoal \\
\hline $168-200$ & $\begin{array}{l}\text { Sandy clayey sediment combined with thick layers of } \\
\text { coarse sand and charcoal }\end{array}$ \\
\hline
\end{tabular}

\section{Description of the pollen diagram}

Both pollen and pollen-spores data suggest a division of two main zones T1 (200$100 \mathrm{~cm} ; 20$ samples) and T2 (100-50 cm, 11 samples). T2 is divided into two subzones T2-a $(100-75 \mathrm{~cm})$ and T2-b $(75-50 \mathrm{~cm})$. In total 77 pollen types were identified and grouped into 4 ecological groups: Grassland, palms, forest and spores (Figs. 4, 5). Pollen concentration oscillates between 217,500 and 277,460 grains $/ \mathrm{cm}^{3}$ and pollen influx between 1,480 and 16,800 grains/cm²/year. Pollenspores sample diversity $(\mathrm{E}(\mathrm{T} 10))$ and pollen-spores richness $(\mathrm{E}(\mathrm{T} 400))$ increase towards the top of the core. Considering that rarefaction to low counts (E(T10)) as a diversity indicator (Matthias et al. 2015), has not been tested in this kind of tropical ecosystem, we have also applied the Shannon index (Hill 1973) to our pollen samples for comparison (ESM - Online Resource 2). The results are highly correlated $(\mathrm{R} 2=0.9955)$ and we selected the representation as rarefaction to a base of 10 counts $(\mathrm{E}(\mathrm{T} 10))$ as a conceptually simpler representation of pollen type diversity within the sample. Microcharcoal concentration and influx decrease from bottom to top of the core $(200$ to $50 \mathrm{~cm})$. 


\subsubsection{Pollen zone $1 \mathrm{~T} 1(200-100 \mathrm{~cm} ; 20$ samples)}

This zone is characterized by high percentages of the ecological group grassland (61 to $80 \%$ ). Poaceae (38-72\%) and Cyperaceae (6-29\%) are frequent in this zone showing an opposed development, Poaceae increasing while Cyperaceae decreases and vice versa. Palm pollen grains have low percentages during this zone. The first occurrence of $M$. flexuosa pollen is at $170 \mathrm{~cm}$ core depth. At the end of the zone $M$. flexuosa increases up to $10 \%$. Forest pollen taxa (14-32\%) are dominated by Moraceae/Urticaceae (9-23\%). Other forest taxa with values lower than $5 \%$ such as Alchornea (0-4 \%), Schefflera (0-2 \%), Melastomataceae (0-4 \%) and Sloanea (0-3 \%) increase towards the top of the zone. Fern spores have a high representation at this interval with values between 7-41 \%. Sticherus-type is the most frequent (11-33 \%) at the core depth from 200 to $165 \mathrm{~cm}$. Later, the values are reduced towards the top of the zone with 3-17\%. Other ferns are represented at this interval in low proportions. Fungal spores occur only in this zone with Gelasinospora (0-1 \%). The Non Pollen Palynomorph (NPP) TEP-2 (Fig. 6) is present only in this zone with values of $0-7 \%$. Pollen concentration at the base of this zone is relatively low compared with the upper part. Values vary from 21,000-80,000 grains $/ \mathrm{cm}^{3}$ from 200 to $160 \mathrm{~cm}$ depth and more abrupt changes in concentration occur from 23,000 up to 277,000 grains $/ \mathrm{cm}^{3}$ from 160 to $105 \mathrm{~cm}$ depth. Pollen influx values show a similar trend to pollen concentration. Microcharcoal particles have the highest concentration of the record; lower values are found at the bottom from 200 to 170 cm (530,000-1,500,000 particles $\left./ \mathrm{cm}^{3}\right)$. From 165 to $105 \mathrm{~cm}$ microcharcoal particles reach values of $3,200,000$ particles $/ \mathrm{cm}^{3}$. Microcharcoal influx has the highest values of the record (51,000-310,340 particles/ $\mathrm{cm}^{2} /$ year) from 200 to $130 \mathrm{~cm}$ depth; afterwards values start to decrease. Pollen-spores richness (E(T400)) and pollenspores sample diversity (E(T10)) tend to increase towards the top of the zone. 


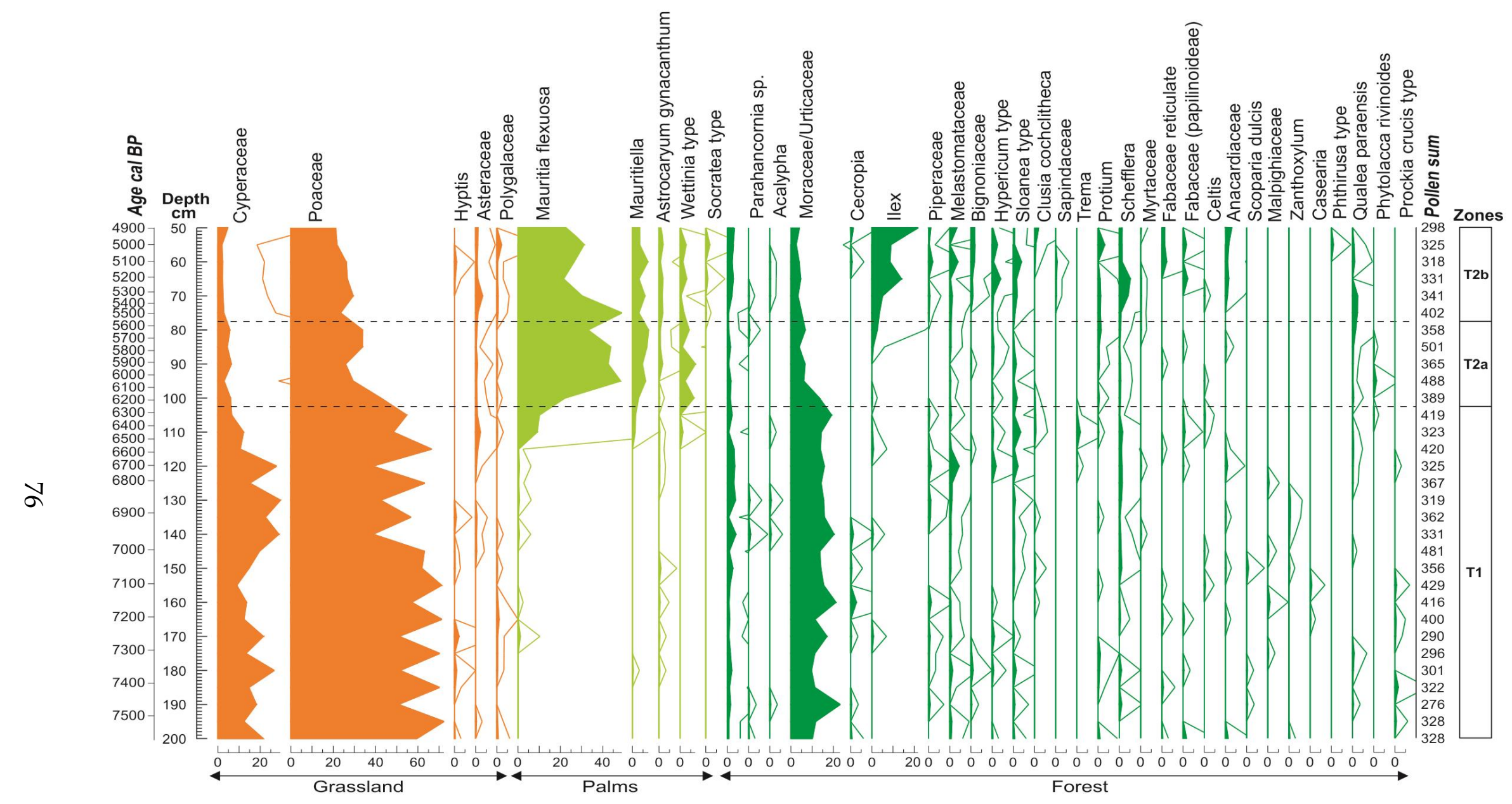

Fig. 4 Pollen and spores percentage diagram showing the taxa grouped into ecological groups: grasslands, palms and forest. The exaggeration factor of each taxon was set to 10 . 


\subsubsection{Pollen zone $2 \mathrm{~T} 2$ (100-50 cm; 11 samples)}

Subzone T2-a (100-75 cm): M. flexuosa and grassland vegetation dominate this zone. The main grassland taxa reduce in pollen values (26-49\%). Poaceae oscillates between 23-42 \% and for Cyperaceae values are between 3-6\%. Palm pollen is dominant (31-57 \%) and is mainly represented by M. flexuosa $(22-49 \%)$ and Mauritiella (3-8 \%). Wettinia-type starts to occur at this zone with values of 0-7 \%. Forest pollen taxa are reduced (10-20\%). Moraceae/Urticaceae pollen is less frequent (4-13\%), but other taxa such as Ilex (0-4 \%) and Qualea paraensis (0-2 \%) increase their percentages in this zone. Fern spores have also changed their frequency (3-19\%). Sticherus-type is markedly reduced with values between 0-2 \%, Lycopodiella cernua starts to increase (0-4\%) as well as trilete verrucate (1-9\%). Pollen concentration fluctuates from high values at the bottom to low values at the top of the zone $\left(112,000-277,000\right.$ grains/ $\left.\mathrm{cm}^{3}\right)$. Pollen influx performs similarly with values between 3,100-9,700 grains/ $\mathrm{cm}^{2} /$ year. Microcharcoal concentration decreases towards the top $\left(840,000-1,400,000\right.$ particles $\left./ \mathrm{cm}^{3}\right)$; the same trend is found for the microcharcoal influx $\left(30,300-59,400\right.$ particles $/ \mathrm{cm}^{2} /$ year $)$.

Subzone T2-a $(75-50 \mathrm{~cm})$ : Low values of microcharcoal concentration and an increase of forest elements dominate the zone. Grassland taxa continue to decrease in the record (27-36 \%). Poaceae have values between 21-30\% and Cyperaceae between 2-5\%. Palm dominance is slightly reduced (27-43\%). M. flexuosa pollen reduces its frequencies (22-31\%) but other palm taxa remain with similar values and slight variations. Forest pollen taxa are increasing their representation with values between $26-46 \%$. Moraceae/Urticaceae pollen is less frequent (3-4 \%) while other forest taxa increase their frequencies, for example Ilex (5-21\%), Alchornea (2-4 $\%)$, Schefflera (1-5\%), Sloanea (1-3\%) and Hypericum-type (1-3\%), among others. Pollen concentration is decreasing toward the top of the zone $(35,000-106,000$ grains $\left./ \mathrm{cm}^{3}\right)$. Pollen influx has values between $1,500-3,100$ grains $/ \mathrm{cm}^{2} /$ year. Microcharcoal concentration decreases towards to the top $(400,000-700,000$ particles $\left./ \mathrm{cm}^{3}\right)$; the same trend is observed for the microcharcoal influx $(17,000$ 26,000 particles/ $\mathrm{cm}^{2} /$ year). Pollen-spores sample diversity and pollen-spores richness have the highest values of the record in this zone. 


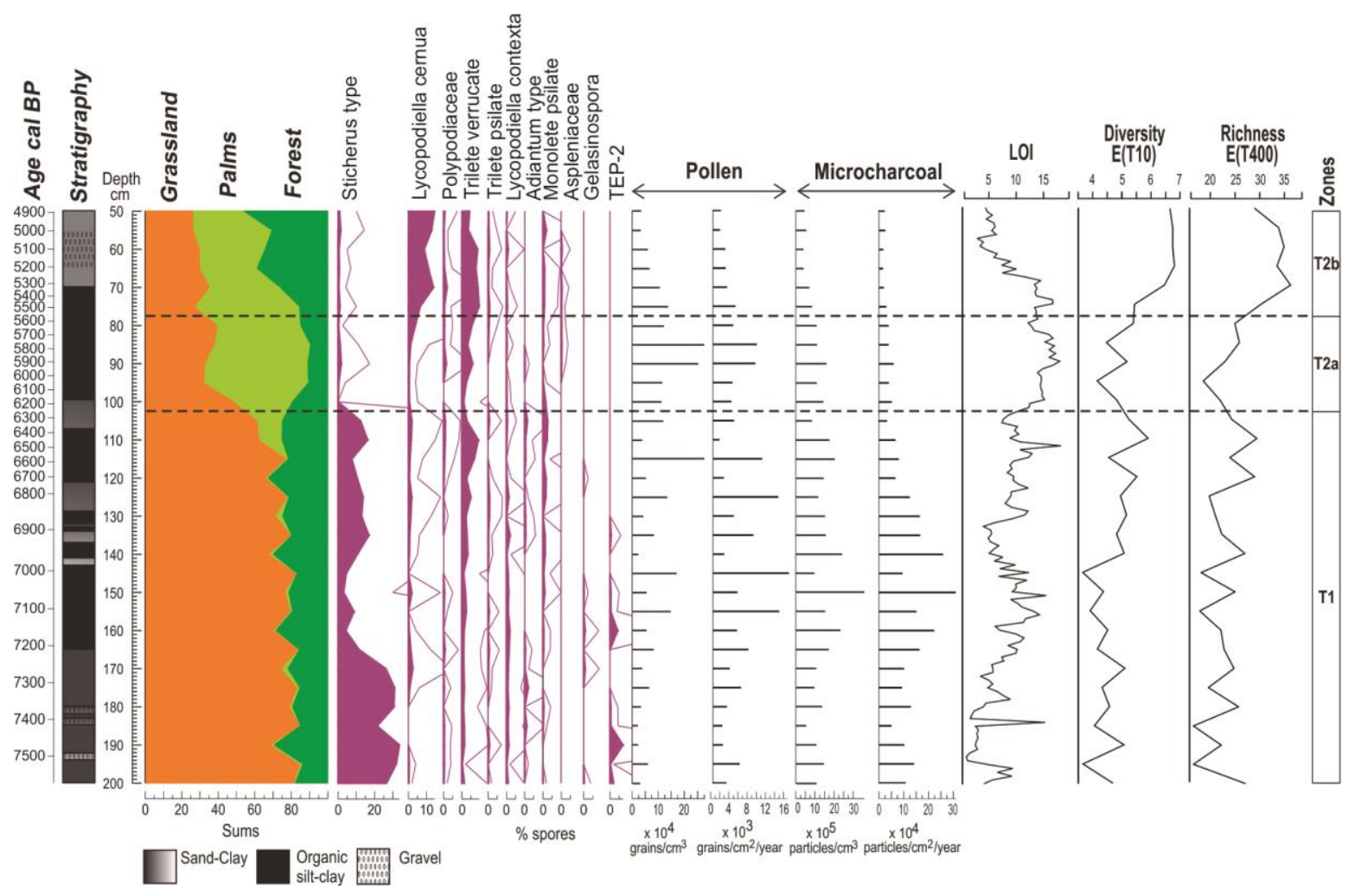

Fig. 5 Pollen sum diagram showing the sum of each ecological group, spore percentages, pollen and microcharcoal concentration, pollen and charcoal influx, LOI, pollen-spores sample diversity $\left(\mathrm{E}\left(\mathrm{T}_{10}\right)\right)$ and pollen-spores richness $\left.\mathrm{E}\left(\mathrm{T}_{400}\right)\right)$

\section{Interpretation and Discussion}

\subsubsection{Chronology of the sediment core Serra do Tepequém}

Our results reflect the usefulness and robustness of the Bayesian age depth modeling used in Bacon, since it reproduces our conceptual considerations and provides realistic age uncertainties. Our dataset provides a good illustration for the power of the outlier detection incorporated in Bacon (Blaauw and Christen 2011). The supposed too young age at $144 \mathrm{~cm}$ might be the result of long period of storage before applying radiocarbon dating analyses as reported in other AMS ${ }^{14} \mathrm{C}$ analyses (Wohlfarth et al. 1998). The sediment core was stored for more than 10 years after recovery, which could favor the growth of some bacteria or spores in this section. Moreover, this part of the section was sampled from a cleaned exposed profile and fungal growth or the presence of rootlets or other young material cannot be discounted. Nevertheless, even if we had chosen the alternative age depth model most of the assigned sample ages would have differed only in the 
order of few hundred years. Thus, despite the problem of reversed dates, this midHolocene pollen diagram represents one of the better dated records for tropical South America.

\subsubsection{The mid-Holocene at Serra do Tepequém}

\subsubsection{Period I (7,570-6,190 cal BP; zone T1)}

Low to high values in the organic matter content, variation in the texture of the sediment core and the change from high to lower sediment accumulation rates in this period, suggest a marked change in climate with a strong effect between dry and wet periods. Such an effect was mainly dominated by the latitudinal influence of the Inter Tropical Convergence Zone (ITCZ) in the area (Cheng et al. 2013; Bustamante et al. 2016). The effect of a longer dry period, due to a longer southward migration of the ITCZ, contributed to the development of more exposed soils that were eroded when the input of water increased in a wet period (Fig. 5). According to Nascimento et al. (2012) the study area is located between residual mountains and intermountain valleys containing the drainage system of Serra do Tepequém. These characteristics are related to the geomorphological origin of the plateau, which is a synclinal valley (Luzardo 2006). Consequently, the sediment composition of the coring site is probably not only reflecting marked changes between periods, but also local changes in the drainage system in which the Serra do Tepequém sediment core is located.

Regarding the vegetation changes in the studied site, small forest areas were mainly represented by some species of Moraceae/Urticaceae, Alchornea and Schefflera, and the dominance of Poaceae and Cyperaceae indicated relatively large savanna areas. The high presence of the fern spore Sticherus-type may also indicate open areas (Rull 1999), besides the presence of an active channel with running water coming from the spring area. Regional fires were present at this time with the highest signal in the record able to be correlated with the dominance of savanna and the considerable cover of the ferns in our study site (Rull 1999). As a local signal of fires and burned soils the fungal spore Gelasinospora was detected. Such a spore occurred only for this period, which therefore supports the hypothesis of probable local fires in a dry period in the area (Fig. 5) (van Geel 1978; Dietre et al. 2016; Herzschuh et al. 2016). Another potential indicator of fires is the 
NPP TEP-2 (Fig. 6), which only occurred when high peaks of microcharcoal were detected and coincided with some maxima of Gelasinospora. The ecological background and origin of TEP-2 are unknown, preventing its inclusion as a support of our interpretations. All these features compared with our sedimentological findings indicate that a longer migration of the ITCZ toward the south facilitated the expansion of grasslands and other creeping pteridophytes (i.e. spores of Sticherus-type, Lycopodiella contexta and L. cernua) between 7,570 until 7,060 cal BP (200 to $150 \mathrm{~cm}$ ) (Fig. 5). The regional signal of fire might also indicate a dry period; however, the impact of human fire use for hunting could have played a role.

For the period between ca. 6,960 to 6,580 cal BP $(140$ to $115 \mathrm{~cm})$ pollen and microcharcoal influx are showing a change in vegetation cover (Fig. 5). The reduction of Poaceae, the increase of Cyperaceae, and the sparse occurrence of $M$. flexuosa, might confirm the beginning of wetter conditions in the study area, together with a physical change in the drainage system, as is reflected in change of sediments in the core. Sediment composition had more variation than in earlier times, showing a reduction in organic matter content and an increase of sandy sediments until 6,710 cal BP $(120 \mathrm{~cm})$. At that time the influence of the Atlantic sea surface temperature (SST) on the ITCZ started to restrict the southward extent of this convective system, therefore reducing the length of the dry season in the area (Haug et al. 2001; Cheng et al. 2013). Even though such a marked change is observed in the different proxies, statistical analyses do not support another subdivision or zone for this period.

From ca. 6,580 to $6,190 \mathrm{cal} \mathrm{BP}$, M. flexuosa rapidly started to expand together with other forest and fern species, colonizing former dry areas. From the physiological point of view, M. flexuosa juvenile plants are shade intolerant and need open areas to succeed (Lasso et al. 2011). At that time, open areas were available and an increase in accumulation of organic matter began, consequently allowing the expansion of young palm juveniles. As to the changes in sediment texture and organic matter content, they are to be expected since spring water availability seems to be dependent on the rainfall and ground water from the plateau. The increase in available moisture in the study site is also reflected in an increase of forest in the area. 


\subsubsection{Period II (6,190-4,900 cal BP; zone T2)}

A period with more humid conditions than before is detected by the presence of more organic sediments together with the reduction trend of microcharcoal concentration and influx toward younger times. At this time the effect of the ITCZ in Serra do Tepequém is reflected in a reduced dry season, due to a more northward position and the changes in sediments might be also related to the development of a swampy area. These wetter conditions are also visible in the vegetation composition and in the increase of plant diversity as indicated by the pollen-spores richness (Fig. 5). A swampy area covered by M. flexuosa and other palms was dominant, and a notable reduction in grasslands, fire and Sticherustype occurred (subzone T2-a, Figs. 4, 5). Rull (1999) showed that some fern spores have a similar performance to charcoal. Both were more abundant in the first phase of the record (T1), and were declining when the charcoal content diminished in this period (T2). The reduction in Sticherus-type and microcharcoal in Serra do Tepequém is followed by an increase in forest taxa and replacement by creeping pteridophytes (increase in spores of Lycopodiella cernua, L. contexta and Polypodiaceae) growing in the savanna (subzone T2-b).

The forest-savanna mosaic persisted, but with the expansion of the swampy area and new forest taxa. The input of coarse sediments to the rill became reduced as well as the regional signal of fire and grasslands. Such reduction of fire due to the increase of wetter conditions has been also found in the Venezuelan savannas for the early mid Holocene (see Climatic conditions section below) (Rull et al. 2013). Another possible explanation for the reduction of the charcoal signal in the sediments of Serra do Tepequém may be the effect of the closeness of the canopy in the area, which might not have allowed charcoal to accumulate easily.

Starting at 6,190 cal BP, conditions were favorable for M. flexuosa to spread out. A swampy area was completely developed and new colonizer species became established. A marked reduction in grasslands is evident, indicating the increase of moisture at that time (Fig. 4). A balance between forest and savanna became established such as in other records (Behling and Hooghiemstra 2000). The pollenspores sample diversity started to increase, reaching continuous higher values at the end of the period. 
From 5,330 cal BP until the end of the record at 4,900 cal BP, the increase in forest elements and the relatively low pollen and charcoal concentrations may indicate an increment of run-off water in the rill, bringing coarse eroded sediments to the coring site. The expansion of forest is supported by the study on M. flexuosa seedlings by Galeano et al. (2015). These authors argued that the distribution pattern of this palm is influenced by rain seasonality combined with local heterogeneous conditions like drainage, flooding and slope, which allow terra firme forest species to establish on better drained places and displace M. flexuosa seedlings. At the end of this second period, better drained places were available for forest to colonize Serra do Tepequém (Fig. 5).

The characteristics of the sediments from $0-50 \mathrm{~cm}$ made it difficult to develop the palaeoecological analyses and interpretation toward recent times. As explained before, this section of sediments of the Serra do Tepequém core was reworked with a mixture of compacted and fragmented sediments. Also the pollen content was very low and oxidized, which did not permit the pollen analysis of this section. The main reason for the reworked material is related to the intense gold and mining activities that the plateau has been experiencing during the last 100 years (Almeida-Filho and Shimabukuro 2002). Many areas are now bare soils due to the water pressure used to wash the plateau surfaces (Fig. 2c), which changed the soil properties and removed the organic content.

\subsubsection{A possible human impact during the mid-Holocene}

Human impact on Serra do Tepequém during mid-Holocene times might not be excluded. The earliest reported human occupation for the Roraima savannas was found in Pedra Pintada (Reis et al. 2008) at $100 \mathrm{~km}$ toward the east from Serra do Tepequém. Such occupation dates ca. 4,000 uncal BP (ca. 4,400 cal BP), even though for Amazonian lowlands the earliest occupation is indicated at ca. 11,200 uncal BP (ca. 13,000 BP) (Roosevelt et al. 1996). In our record, the dry conditions detected from the huge amount of charcoal particles and savanna dominance could be also a signal of human impact in the area, but, since our record does not include a macro charcoal analysis to detect a local signal of charcoal, such assumptions should be taken with caution. A possible sign of local fires in our study site is the presence of Gelasinospora fungal spores, an indicator of past local fire occurrence (Dietre et al. 2016; Herzschuh et al. 2016). The presence of this spore together with 
the layers of charcoal found in the sediments (Table 2) may indicate possible human influence in the area. In addition, the changes in forest and fern composition for the wettest period of our record possibly indicate an abandonment of the land. Our study shows that the area has a potential for archaeological research, which would allow us a clear view of the role of ancient cultures in relation to vegetation changes and fire.

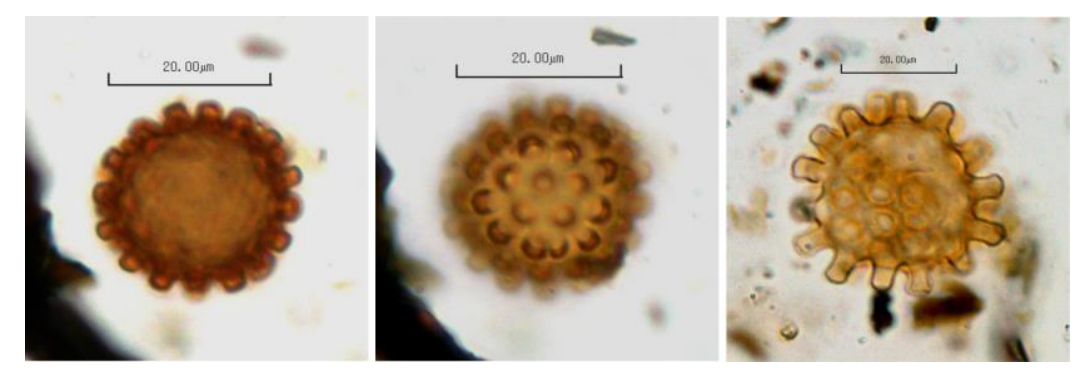

Fig. 6 TEP-2, single circular microfossils with tubular protuberances and 22-26 × 21-25 $\mu \mathrm{m}$ size. The tubular protuberances are ca. $2 \mu \mathrm{m}$ in diameter and ca. $2.5 \mu \mathrm{m}$ in length. The space between tubules is ca. 2-2.5 $\mu \mathrm{m}$. This macrofossil was reported from a dry period when open areas (grasslands) dominated

\subsubsection{The mid-Holocene at Roraima savannas in Brazil}

Despite the nature of Serra do Tepequém, an isolated plateau surrounded by tropical rainforest lying ca. $15 \mathrm{~km}$ from the main savanna region of Roraima, we expect that the effect of the ITCZ on vegetation development shows similar trends. The oldest sediment record from Roraima State is Lago Caracaranã with an age of ca.10,020 uncal BP (11,500 cal BP) (Simões Filho et al. 2010; Cordeiro et al. 2014). This studied site covers the entire Holocene and was analyzed using mineralogical analyzes such as TOC, charcoal, silicate, kaolinite and quartz. The results suggest that between 7,600 and 6,000 cal BP there was an expansion of the dry season. These conditions increased the erosion in soils with high input of quartz, kaolinite and calcite into the lake. Furthermore, the study of Cordeiro et al. (2014) in the same lake showed that the highest maxima in the microcharcoal record are from the early to mid-Holocene, also pointing to a dry period. At Serra do Tepequém the effect of a longer southward migration of the ITCZ was also reflected in more open vegetation and a high signal of regional fires (zone T1) (Figs. 4, 5). Simões Filho et al. (2010) suggested that the beginning of the wetter conditions in Roraima State started at 6,000 cal BP, with a reduction of fires from mid- to late Holocene as 
suggested from the microcharcoal analyses (Cordeiro et al. 2014). This coincides with the maximum vegetation cover of $\mathrm{M}$. flexuosa, the high values of LOI and the reduction of microcharcoal at the Serra do Tepequém coring site. Although the study of Lago Caracaranã does not use palynological data and has a different geomorphological setting from Serra do Tepequém, the effect of a southward position of the ITCZ is reflected by a dry period for ca. 7,600 and 6,000 cal BP with a change to wetter conditions toward more recent times. Furthermore, the Holocene vegetation dynamics in the eastern part of the Roraima savannas were reconstructed by Toledo and Bush (2009) at Jacaré Lake, which is located $7 \mathrm{~km}$ from Lago Caracaranã. They found vegetation changes related to forest expansion from 5,700 to 4,700 uncal BP (ca. 6,500 to 5,400 cal BP) coinciding with the findings of wetter conditions at Lago Caracaranã and Serra do Tepequém.

\subsubsection{A regional overview of the mid-Holocene vegetation changes in northern savannas in South America}

\subsubsection{The establishment of M. flexuosa}

The best documented history of forest-savanna dynamics from near Serra do Tepequém comes from the southeastern part of the Gran Sabana region of Venezuela, with records from ca. 12,000 cal BP to the present (Leal et al. 2013; Ballesteros et al. 2014; Rull and Montoya 2014; Rull et al. 2015). The Gran Sabana region lays on sedimentary rocks, sandstones, claystones and conglomerates of the middle Proterozoic Roraima formation showing similar geological features as those found at Serra do Tepequém (Almeida-Filho and Shimabukuro 2002; Montoya et al. 2011b). For the Roraima formation, Serra do Tepequém is the first record reporting an early establishment with a continuous occurrence of $M$. flexuosa stands in the mid-Holocene, starting at ca. 6,600 cal BP. The increase of this palm is related to wetter conditions together with a local availability of water. In our study site, regional fires showed a marked decrease towards the mid to late Holocene, with an increase of M. flexuosa and forest taxa expansion due to the increase in wetter conditions (Fig. 5). These features show a different development of Mauritia stands compared with those reported by Rull et al. (2013) in the Gran Sabana region and Meneses et al. (2013) at the southern part of the Roraima savannas for the late Holocene. In Serra do Tepequém, a higher signal of regional 
fires was present when grasses and open vegetation were the dominant vegetation in the area. These features are in agreement with the expansion of savannas in the Gran Sabana region and the southern part of Roraima, but not when there was the expansion of $M$. flexuosa and forest taxa. This development might be explained as the effect of the ITCZ on the plateau. A wetter period favored the development of taxa that were able to grow in frequently flooded areas, as is reported in the sedimentological record of Serra do Tepequém. Such wetter conditions could be a factor in the reduction of the microcharcoal signal, since a reduction of fires would be expected in a wetter environment. But as mentioned before, forest canopy can also be a limiting factor for microcharcoal deposition in the sediments and it should be considered as a possible explanation.

At the llanos Orientales in Colombia (Berrio et al. 2002; Hooghiemstra and Berrio 2007), the expansion of Mauritia was found around ca. 4,000 to 3,500 uncal BP (4,400 to 3,700 cal BP) and, as was found earlier in Serra do Tepequém, the development of these palms is related to the change to wetter conditions in the savanna with a shorter dry season and increased precipitation. For the late Holocene an increase in human impact is linked to savanna expansion and recurrent fires (Behling and Hooghiemstra 1998, 2000; Berrio et al. 2002; Velez et al. 2005; Hooghiemstra and Berrio 2007). As fires were not analyzed in these records, the interplay of M. flexuosa and fire cannot be compared. However, Serra do Tepequém reflects similar development of $M$. flexuosa when savanna vegetation was also contracting in the Llanos Orientales records (Hooghiemstra and Berrio 2007).

\subsubsection{Climatic conditions: the effect of the ITCZ on different records}

The latitudinal effect of the ITCZ for the mid-Holocene in northern South America had an influence on the length of the dry and wet seasons in each study area (Cheng et al. 2013; Bustamante et al. 2016). The timing and impact on the diverse study sites might vary due to the different latitudinal positions and local features that were then conditioning the dynamics between forest and savanna expansion.

Conditions were drier in Serra do Tepequém for the recorded period between ca. 7,570 to 6,600 cal BP before the expansion of forest and M. flexuosa started, as the ITCZ was in a southward position at that time (Cheng et al. 2013). This is also 
shown in the records from El Paují (Montoya and Rull 2011; Montoya et al. 2011a; Rull et al. 2013) and Laguna Encantada (Rull et al. 2013; Ballesteros et al. 2014). These records display the dominance of open vegetation when fires were more intense. After these dry conditions, charred particles began to be reduced in the three records, indicating a wetter climate. As a result, around 7,000 cal BP at the Laguna Encantada and El Paují, the rainforest expanded (Rull et al. 2013; Ballesteros et al. 2014). In the case of Serra do Tepequém, the forest-savanna mosaic remained stable with more dominance of savanna grasslands and a high regional fire signal until ca. 6,600 cal BP when Mauritia stands showed their highest expansion in the record. Ballesteros et al. (2014) also reported a synergistic action between reduction in fires and wetter conditions that determined the development of rainforest around ca. 6,700 uncal BP (7,500 cal BP) in Laguna Encantada. Such changes in vegetation and fires due to a change from dry to wetter conditions are comparable with speleothem records (Cheng et al. 2013). Records from northeastern Brazil and eastern Amazonia showed a drastic shift from severely dry to substantially wet conditions in the region (Cheng et al. 2013). The llanos Orientales records show changes in climate from dry to wetter conditions at different time scales. For the western part of these savannas the climate changed to wetter conditions from ca. 7,100 and 6,100 uncal BP (8,000 and 7,000 cal BP) and for the eastern part from ca. 6,400 and 5,300 uncal BP (7,300 and 6,000 cal BP) (Hooghiemstra and Berrio 2007). Serra do Tepequém shows similar patterns from the period between ca. 6,960 and 6,580 cal BP in which wetter conditions began to be noticed. Afterwards at ca. 6,200 cal BP the full development of M. flexuosa palm stands and the change in composition of forest then corroborate a more dynamic and humid environment. Behling and Hooghiemstra (2000) considered that the vegetation of the mid-Holocene period was little influenced by humans in the savannas of the Llanos Orientales, but this assumption should be considered with caution since they have not included a charcoal analysis to confirm possible human practices and fire regime dynamics in the area. Those authors also concluded that the dynamics of the forest-savanna boundary are determined primarily by precipitation change and to a lesser extent by changes in fire frequency, soil conditions and biotic factors. In our study site, precipitation change also played an important role in the dynamics of the forest-savanna mosaics, but the local conditions of the study site, such as the geomorphological origin of the plateau 
(altitude, drainage system, isolated plateau etc.), are influencing the dynamics on vegetation at the same level (Luzardo 2006). The effect of local fires cannot be strongly argued with our results, but at a regional scale the fire signal is showing an effect.

\section{Conclusions}

The regional increase in wetter conditions during the mid-Holocene was detected in Serra do Tepequém, and was reflected in changes in the deposition of sediments, vegetation and fire dynamics. Our results show that a dry period with reduced wet seasons occurred around 7,570 to 6,190 cal BP. In that period, a forestsavanna mosaic mainly dominated. Grassland taxa and creeping pteridophytes were present in the area, in agreement with other palaeoecological records reporting dry conditions for northern South America.

The Serra do Tepequém sediments reveal an increase in wetter conditions between ca. 6,190 to 4,900 cal BP. Such changes promoted new arrangements of forest, pteridophytes and an early increase in M. flexuosa palm. As wetter conditions intensified, our findings exhibit a decrease in savanna vegetation together with a reduction of regional fires and hence new forest species starting to colonize the study area.

The timing of the change to wetter conditions in Serra do Tepequém is slightly different compared with the records of the Llanos Orientales and Gran Sabana, probably due to the latitudinal influence of the ITCZ and the particular geomorphological features of each studied site. Our results are complementary with the Gran Sabana findings of the records for el Paují and Laguna Encantada with an increase in moisture around ca. 7,000 and 6,600 cal BP. Regarding the Llanos Orientales in Colombia, changes from dry to wetter conditions with similar timing and vegetation arrangements were found in the record from Laguna Sardinas.

Our study shows that the early increase in M. flexuosa developed differently to the increase in fire and savanna expansion found in the savanna region in Venezuela. The M. flexuosa expansion in Serra do Tepequém may indicate a local geomorphological and climatic setting besides a possible land use derived from ancient cultures in the area. Human impact should be corroborated with further 
palaeoecological and archaeological studies in the region, as it is not completely clear what impact such cultures had on vegetation.

\section{Acknowledgements}

We would like to thank Siria Biagioni for the charcoal analysis suggestions and Alejandra Leal for helping on pollen identification. Encarni Montoya and unknown reviewers are thanked for their detailed comments on an earlier version of this manuscript. Special thanks to Thomas Giesecke, Sonia Fontana, Kartika Hapsari and Claudia Kühn for their constant support and meaningful discussions during this project phase. The DAAD-COLFUTURO scholarship is thanked for funding the first author. The fieldwork was funded by the projects 471109/2003-7 and 304333/2003-4 from the CNPq: Geoquímica de Sedimentos e Solos Atuais como Parâmetros de Avaliação da Ação do Intemperismo Tropical na Amazônia: Importância Geológico-Arqueológica e Sócio-Econômica - GEOSEDINTAMA. 


\section{References}

Absy ML (1979) A Palynological Study of Holocene Sediments in the Amazon Basin. PhD thesis, University of Amsterdam, The Netherlands

Almeida-Filho R, Shimabukuro YE (2002) Digital processing of a Landsat-TM time series for mapping and monitoring degraded areas caused by independent gold miners, Roraima State, Brazilian Amazon. Remote Sens Environ 79:4250

Ballesteros T, Montoya E, Vegas-Vilarrubia T et al. (2014) An 8700-year record of the interplay of environmental and human drivers in the development of the southern Gran Sabana landscape, SE Venezuela. Holocene 24:1,757-1,770

Barbosa RI, Miranda IS (2004) Fitofisionomias e diversidade vegetal das Savanas se Roraima [Phytophysiognomies and plant diversity of the Roraima savanas]. In: Barbosa RI, Xaud HAM, Costa e Souza EM (eds) Savanas de Roraima: Etnoecologia, biodiversidade e potencialidades agrossilvipastoris. FEMACT, Boa Vista, pp 61-78

Barbosa RI, Campos C, Pinto, Fearnside PM (2007) Os 'Lavrados' de Roraima: Biodiversidade e Conservação de Savanas Amazônicas Brasileiras. Functional Ecosystems and Communities 1:29-41

Barni PE, Pereira VB, Manzi AO et al. (2015) Deforestation and Forest Fires in Roraima and their Relationship with Phytoclimatic Regions in the Northern Brazilian Amazon. Environ Manage 55:1,124-1,138

Behling H, Hooghiemstra H (1998) Late Quaternary paleoecology and paleoclimatology from pollen records of the savannas of the Llanos Orientales in Colombia. Palaeogeogr Palaeoclimatol Palaeoecol 139:251-267

Behling H, Hooghiemstra H (1999) Environmental history of the Colombian savannas of the Llanos Orientales since the Last Glacial Maximum from lake records El Pinal and Carimagua. J Paleolimnol 21:461-476 
Behling H, Hooghiemstra H (2000) Holocene Amazon rainforest-savanna dynamics and climatic implications: High-resolution pollen record from Laguna Loma Linda in eastern Colombia. J Quat Sci 15:687-695

Bennett KD (1996) Determination of the number of zones in biostratigraphical sequences. New Phytol 132:155-170

Bennett KD (2009) Psimpoll 4.27: C program for plotting pollen diagrams and analyzing pollen data. Queen's University of Belfast, Department of Archaeology and Palaeoecology. http://www.chrono.qub.ac.uk/psimpoll/psimpoll.html. Last accessed July 2015

Berrio JC, Hooghiemstra H, Behling H, Botero P, van der Bog K (2002) LateQuaternary savanna history of the Colombian Llanos Orientales from Lagunas Chenevo and Mozambique: a transect synthesis. Holocene 12:35-48

Beserra Neta LC, Tavares SS, Costa ML (2015) Tepequém mountains: a relict landscape in the northern Amazon. In: Vieira et al. (eds) Landscapes and Landforms of Brazil. Springer, Dordrecht, pp 265-272

Blaauw M, Christen JA (2011) Flexible paleoclimate age-depth models using an autoregressive gamma process. Bayesian Anal 6:457-474

Brasil (1975) Geología, gemorfologia, vegetação e uso potencial da terra. Departamento Nacional da Produção Mineral. Projeto RADAMBRASIL.Folha NA.20 Boa Vista e parte das folhas NA.21 Tumucumaque, NB.20 Roraima e NB.21

Bustamante MG, Cruz FW, Vuille M et al. (2016) Holocene changes in monsoon precipitation in the Andes of NE Peru based on $\delta 18 \mathrm{O}$ speleothem records. Quat Sci Rev 146:274-287

Carreira LMM, Silva MF, Lopes JRC, Nascimento LAS (1996) Catálogo de pólen das leguminosas da Amazônia Brasileira. Museu paraense Emílio Goeldi, Belém 
Cordeiro RC, Turcq B, Moreira LS et al. (2014) Palaeofires in Amazon: Interplay between land use change and palaeoclimatic events. Palaeogeogr Palaeoclimatol Palaeoecol 15:137-151

Cheng H, Sinha A, Cruz FW et al. (2013) Climate change patterns in Amazonia and biodiversity. Nat Commun 4:1,411

Desjardins $\mathrm{T}$ (1996) Changes of the forest-savanna boundary in Brazilian Amazonia during. Holocene 108:749-756

Dietre B, Walser C, Kofler W et al. (2016) Neolithic to Bronze Age (4850-3450 cal. $\mathrm{BP})$ fire management of the Alpine Lower Engadine landscape (Switzerland) to establish pastures and cereal fields. Holocene 26:1-16

Fægri K, Iversen J (1989) In: Fægri K, Kaland PE, Krzywinski K (eds) Textbook of Pollen Analysis, 4th edn. Wiley, Chichester

Flantua SGA, Hooghiemstra H, Grimm EC et al. (2015) Updated site compilation of the Latin American Pollen Database. Rev Palaeobot Palynol 223:104-115

Galeano A, Urrego LE, Sánchez M, Peñuela MC (2015) Environmental drivers for regeneration of Mauritia flexuosa L.f. in Colombian Amazonian swamp forest. Aquat Bot 123:47-53

Haug GH, Hughen KA, Sigman DM et al. (2001) Southward migration of the intertropical convergence zone through the Holocene. Science 293:1,3041,308

Heiri O, Lotter AF, Lemcke G (2001) Loss on ignition as a method for estimating organic and carbonate content in sediments: Reproducibility and comparability of results. J Paleolimnol 25:101-110

Herzschuh U, Birks JB, Laepple T et al. (2016) Glacial legacies on interglacial vegetation at the Pliocene-Pleistocene transition in NE Asia. Nature 7. doi:10.1038/ncomms11967

Hill MO (1973) Diversity and evenness: a unifying notation and its consequences. Ecology 54:427-473 
Hooghiemstra H, Berrio JC (2007) South America: Pollen record from the Colombian savannas. In: Elias S (ed) Encyclopedia of Quaternary Science. Elsevier, Amsterdam, pp 2,654-2,659

INMET (2015) Instituto Nacional de Metereologia, Monitoramento das Estações Convencionais Ministério da Agricultura, Pecuária e Abastecimento. Available in: http://www.inmet.gov.br. Last accessed July 2015

Lasso CA, Rial A, Matallana C et al. (eds) (2011) Biodiversidad de la cuenca del Orinoco. II Áreas prioritarias para la conservación y uso sostenible. Instituto de Investigación de Recursos Biológicos Alexander von Humboldt, Ministerio del Ambiente, Vivienda y Desarrollo Territorial, WWF Colombia, Fundación Omacha, Fundación La Salle de Ciencias Naturales e Instituto de Estudios de la Orinoquia (Universidad Nacional de Colombia). Bogotá, D.C., Colombia

Lasso CA, Rial A, González-BV (eds) (2013) Morichalesy canangunchales de la Orinoquia y Amazonia: Colombia - Venezuela. Parte I. Serie Editorial Recursos Hidrobiológicos y Pesqueros Continentales de Colombia. Instituto de Investigación de Recursos Biológicos Alexander von Humboldt (IAvH). Bogotá, D. C., Colombia

Leal A, Bilbao B, Berrío J et al. (2011) A pollen atlas of premontane woody and herbaceous communities from the upland savannas of Guayana, Venezuela. Palynology 35:226-266

Leal A, Bilbao B, Berrío JC (2013) A Contribution to Pollen Rain Characterization in Forest-Savanna Mosaics of the Venezuelan Guayana and its Use in Vegetation Reconstructions from Sedimentary Records. Am J Plant Sci 4:3352

López-Martínez C, Lara A, Rull V et al. (2010) Additions to the Pantepui pollen flora (Venezuelan Guayana): the Maguire Collection. Collectanea Botanica 29:31-49

Luzardo R (2006) O metamorfismo da serra Tepequém (estado de Roraima). Masters thesis, Universidade Federal do Amazonas 
Marchant R, Almeida L, Behling H et al. (2002) Distribution and ecology of parent taxa of pollen lodged within the Latin American Pollen Database. Review Palaeobot Palynol 121:1-75

Matthias I, Semmler MSS, Giesecke T (2015) Pollen diversity captures landscape structure and diversity. J Ecol 103:880-890

Meneses MENS, Costa ML, Behling H et al. (2013) Late Holocene vegetation and fire dynamics from a savanna-forest ecotone in Roraima state, northern Brazilian Amazon. J S AM Earth Sci 42:17-26

Miranda IS, Absy ML (2000) Fisionomia Das Savanas De Roraima, Brasil 1. Acta Amazonica 30:423-440

Miranda IS, Absy ML, Rebelo GH (2002) Community Structure of Woody Plants of Roraima Savannah, Brazil. Plant Ecol 164:109-123

Montoya E, Rull V (2011) Gran Sabana fires (SE Venezuela): a paleoecological perspective. Quat Sci Rev 30:3,430-3,444

Montoya E, Rull V, Nogué S (2011a) Early human occupation and land use changes near the boundary of the Orinoco and the Amazon basins (SE Venezuela): Palynological evidence from El Paují record. Palaeogeogr Palaeoclimatol Palaeoecol 310:413-426

Montoya E, Rull V, Stansell ND et al. (2011b) Forest-savanna-morichal dynamics in relation to fire and human occupation in the southern Gran Sabana (SE Venezuela) during the last millennia. Quat Res 76:335-344

Montoya E, Rull V, Vegas-Vilarrúbia T (2012) Non-pollen palynomorph studies in the neotropics: The case of Venezuela. Rev Palaeobot Palynol 186:102-130

Nascimento FA, Tavares-Junior SS, Beserra-Neta LC (2012) Estudo dos compartimentos geomorfológicos na serra do tepequém - RR, através de fotointerpretação em imagens de sensores remotos e produtos integrados via ihs. Revista Geonorte 2:1,464-1,474 
Oksanen J, Blanchet FG, Kindt R et al. (2015) Vegan: Community Ecology Package. $\mathrm{R}$ package version 2.3-0. http://CRAN.R-project.org/package=vegan. Last accessed August 2015

R Development Core Team (2015) R: a Language and Environment for Statistical Computing. R Foundation for Statistical Computing, Vienna, Austria. http://www.R-project.org. Last accessed August 2015

Rangel-Ch JO, Bogotá RG, Jiménez-Bulla LC (2001) Atlas palinológico de la Amazonia Colombiana. IV. Familia Arecaceae. Caldasia 23:281-300

REFLORA (2015) List of species of the Brazilian Flora. Rio de Janeiro Botanical Garden. Available in: http://floradobrasil.jbrj.gov.br/. Last accessed November 2015

Reimer PJ, Bard E, Bayliss A et al. (2013) IntCal13 and Marine13 radiocarbon age calibration curves, 0-50,000 years cal BP. Radiocarbon 55:1,869-1,887

Reis NJ, Schobbenhaus C, Costa F et al. (2008) Pedra Pintada, RR - Ícone do Lago Parime. In: Winge M, Schobbenhaus C, Souza CRG, et al (eds) Sítios Geológicos e Paleontológicos do Brasil Ícone do Lago Parime Ícone do Lago Parime. Available in: http://www.unb.br/ig/sigep/sitio012/sitio012.pdf. Last accessed January 2016

Roosevelt AC, Lima da Costa M, Lopes Machado C et al. (1996) Paleoindian Cave Dwellers in the Amazon: The Peopling of the Americas. Science 272:373-384

Roubik DW, Moreno E (1991) Pollen and Spores of Barro Colorado Island. Monographs in Systematic Botany 36. Missouri Botanical Garden, St. Louis

Rull V (1999) A palynological record of a secondary succession after fire in the Gran Sabana, Venezuela. J Quat Sci 14:137-152

Rull V (2003) An illustrated key for the identification of pollen from pantepui and the gran sabana (eastern Venezuelan Guayana). Palynology 27:99-133

Rull V, Montoya E (2014) Mauritia flexuosa palm swamp communities: Natural or human-made? A palynological study of the Gran Sabana region (northern South America) within a neotropical context. Quat Sci Rev 99:17-33 
Rull V, Montoya E, Nogué S et al. (2013) Ecological palaeoecology in the neotropical Gran Sabana region: Long-term records of vegetation dynamics as a basis for ecological hypothesis testing. Perspect Plant Ecol Evol Systematics 15:338-359

Rull V, Montoya E, Vegas-Vilarrúbia T et al. (2015) New insights on palaeofires and savannisation in northern South America. Quat Sci Rev122:158-165

Simões Filho FL, Turcq BJ, Sifeddine A (2010) Mudanças paleoambientais do contato floresta-savana de Roraima durante o Holoceno. In: Barbosa RI, Ferreira-Melo V (eds) Roraima: Homem, Ambiente e Ecologia. FEMACT, Boa Vista, pp 257-282

Stockmarr J (1971) Tablets with spores used in absolute pollen analysis. Pollen et Spores13:615-621

Toledo M, Bush MB (2009) History of Amazonian savannas in the last 10,000 years. Palaeoecological records of environmental human occupation. VDM Verlag Müller, Saarbrücken

USGS (2014) Earth explorer from the U.S. Geological Survey. http://earthexplorer.usgs.gov/. Last accessed October 2014

Van Geel B (1978) A palaeoecological study of Holocene peat bog sections in Germany and The Netherlands, based on the analysis of pollen, spores and macro- and microscopic remains of fungi, algae, cormophytes and animals. Rev Palaeobot Palynol 25:1-120

Velez MI, Wille M, Hooghiemstra $\mathrm{H}$ et al. (2005) Integrated diatom-pollen based Holocene environmental reconstruction of lake Las Margaritas, eastern savannas of Colombia. Holocene 8:1,184-1,198

Wohlfarth B, Skog G, Possnert G et al. (1998) Pitfalls in the AMS radiocarbondating of terrestrial macrofossils. J Quat Sci 13:137-145 


\section{Supplementary material}

Mid-Holocene vegetation dynamics with an early expansion of Mauritia flexuosa palm trees inferred from the Serra do Tepequém in the savannas of Roraima State in Amazonia, northwestern Brazil

Journal of Vegetation History and Archaeobotany

Authors

Paula A. Rodríguez-Zorro*(1), Marcondes Lima da Costa(2), Hermann Behling(1)

(1) Georg-August-University of Göttingen, Albrecht-von-Haller Institute for Plant Sciences. Department of Palynology and Climate Dynamics, Untere Karspüle 2, 37073 Göttingen, Germany

(2) Universidade Federal do Pará (UFPA), Instituto de Geociencias, Av. Augusto Correa 1, Guamá, 66075-110 Belém, Brazil

${ }^{*}$ Corresponding author: Paula A. Rodríguez-Zorro, e-mail address: paula.rodriguez@biologie.uni-goettingen.de 


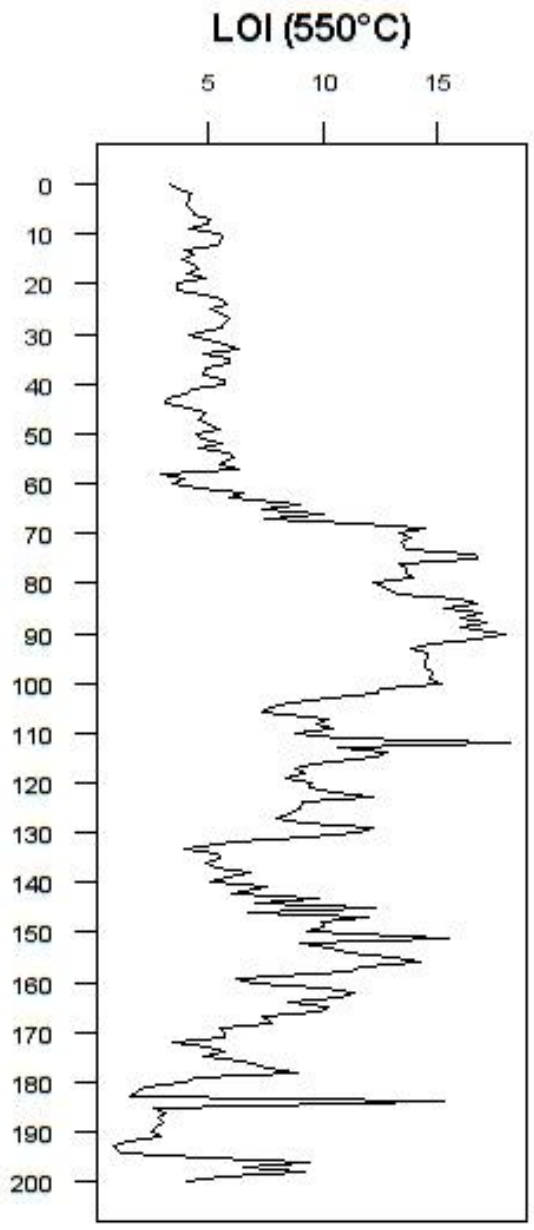

Online Resource 1 complete curve of loss on ignition analysis (LOI) of Serra do Tepequém sediment core. 

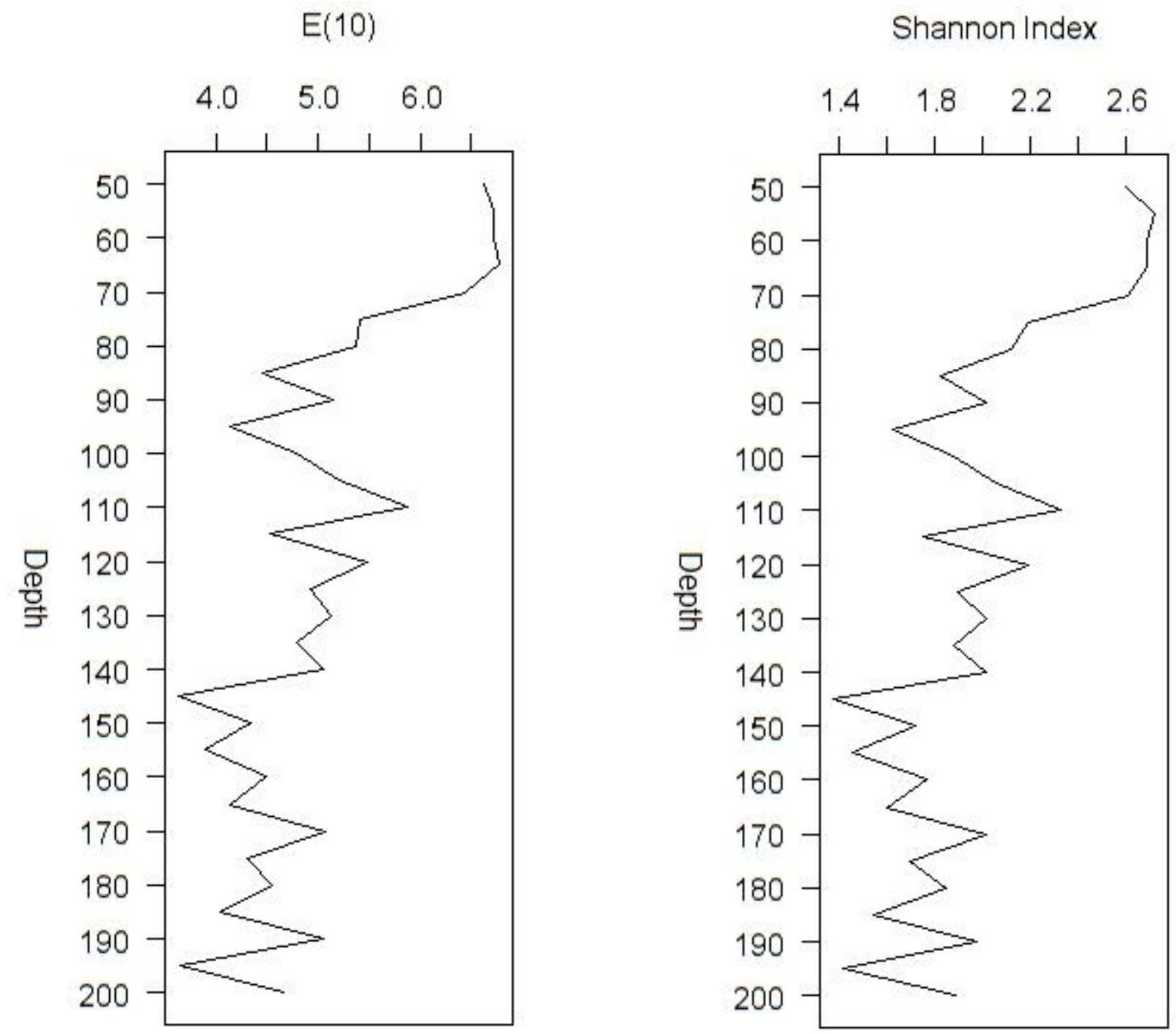

Online Resource 2. Rarefaction to 10 counts and Shannon index from Serra do Tepequém (Correlation $\left.\mathrm{R}^{2}=0,995\right)$. 


\section{CHAPTER 4}

\section{Early and late Holocene Vegetation Dynamics in the Rio Negro Amazon Region and Resilience of Rainforest to Climate Change and River Dynamics}

Paula A. Rodríguez-Zorro ${ }^{1}$, Bruno Turcq ${ }^{2,3,4}$, Renato C. Cordeiro ${ }^{5}$, Luciane S. Moreira ${ }^{5}$, Renata L. Costa ${ }^{5}$, Marcelo C . Bernardes ${ }^{5}$, Arnaldo C. Filho ${ }^{6}$, Crystal, H. McMichael $^{7}$ and Hermann Behling ${ }^{1}$

1 Department of Palynology and Climate Dynamics, Georg-August-University of Göttingen, Germany

2 IRD, University of Sorbonne, CNRS-MNHN, Paris, France -3 LOCEAN, University Pierre and Marie Curie, Paris, France- 4 Cayetano Heredia University, Lima, Perú

5 Geochemistry department, Federal Fluminense University, Brazil

6 Agroicone, Brazil

7 Institute for Biodiversity and Ecosystem Dynamics, University of Amsterdam, Amsterdam, Netherlands

Submitted to the Journal of Quaternary Research. 


\section{Abstract}

The Rio Negro valley region in the Amazon contains the largest black water river system in the world being one of the poorest studied regions of the Amazon lowlands. A $330 \mathrm{~cm}$-long sediment core was collected from the Lake Acarabixi and was analyzed using pollen, spores, microcharcoal, and geochemical analyses. The aim of this study was to detect changes in vegetation assemblages in the early and late Holocene besides the role of climate, river dynamics and possible human impact in the middle-upper part of the Rio Negro in north Amazonia. For the early Holocene (10,840 to 8240 cal yr BP), open forest with herbs occurred, reflecting reduced precipitation with a seasonal climate. Moreover, a highly dynamic river deposited a high amount of coarse sediments into the lake as a result of the filling of the Rio Negro valley, which finished around 8000 cal yr BP in the Lake Acarabixi. A large hiatus in sedimentation occurred during the middle part of the Holocene. During the late Holocene (1600 to $650 \mathrm{cal} \mathrm{yr} \mathrm{BP)} \mathrm{more} \mathrm{lacustrine} \mathrm{phases}$ were observed. Forests were closed reflecting a wetter climate with no or a short annual dry season. There were no drastic changes in vegetation but flooding tolerant species were more frequent. Our unique record from the remote middleupper part of Rio Negro shows that Amazon forests were resilient to changes in climate and river dynamics during the Holocene.

Keywords: Holocene, Igapó forest, black water river, fire, resilience, Brazil, Amazon 


\section{Introduction}

The Amazon Basin is the largest continuous tract of rainforest of the world, and is a biodiversity hot spot estimated to contain ca. 16,000 tree species (Ter Steege et al., 2013). Amazonian forests store ca. $50 \%$ of tropical forest carbon and play a vital role in global water, energy, and carbon cycling (Levine et al., 2016). The Amazon possesses the largest black water river in the world, Rio Negro, with a basin area of ca. 700,000 km² (Goulding et al., 2003; Latrubesse and Franzinelli, 2005). This black water river is characterized by high humic acid concentrations and low quantities of suspended matter in which its alluvial soils are extremely poor in nutrients and very acidic, resulting in large infertile floodplains of poor autochthonous primary productivity (Junk et al., 2011; Montero, 2012; Moran, 1995). These floodplains are locally called Igapós and the Igapó forest is one of the most species-poor late successional floodplain forest types in the Amazon (Junk et al., 2010). In contrast to the hyper-dyverse forests of Amazonia, terrestrial and aquatic herbaceous plants are scarce in Igapós and many whitewater species are absent because of the low fertility and/or low pH (Junk et al., 2010; Montero et al., 2012). However, the Igapó forests are home of several endemic tree species such as the family Lecythidaceae (Montero et al., 2012 and literature cited therein).

A combination of factors, such as geomorphology, climate and hydrology, acting at different spatial and temporal scales, control the floristic variation of the Igapó forest along the Rio Negro (Montero, 2012; Montero and Latrubesse, 2013). The development of the Rio Negro floodplain in the late Quaternary included drastic geomorphological and hydrological changes (Latrubesse and Franzinelli 1998, 2005). Beginning ca. 14,000 years ago, the river has acted as a progradational system that has filled the valleys in downstream series and resulted in alluvial floodplains and associated anabranching channel systems (Latrubesse and Franzinelli 1998, 2005).

Additionally, the climate may have had an effect on the vegetation and water flux dynamics. The modern climate of the middle to upper Rio Negro Basin has relatively stable temperature regime and precipitation is primarily driven by the latitudinal movements of the Inter Tropical Convergence Zone (ITCZ) and also by convective activity that originates from the South American Monsoon System (SAMS) (Vuille et al., 2012). In consequence, the combination of the 
geomorphology and climate in the area produce flood amplitudes of ca. $3.6 \mathrm{~m}$ at the upper sections to $9.3 \mathrm{~m}$ in the lower sections of the Rio Negro. This causes the Igapó forests to flood from ca. 50 to 230 days/year (Montero et al., 2012). Therefore, the river dynamics as main driver on the ecology of such environments can be studied through palaeoecological studies in order to understand how they have changed through the time and thus the ecosystems responses during the past.

Despite the global importance of Amazonia, its past remains particularly understudied. Palaeoecological studies in the tropics have increased (Flantua et al., 2015), but new detailed studies from different regions in the Amazonia would contribute to understand the floodplain and the landscape dynamics through the Holocene, as most of Amazonia is dominated by fluvial processes. In remote regions like the middle-upper part of the Rio Negro Basin, vegetation and ecological studies are scarce. The majority of floristic inventories in the Igapó forests have been carried at the lower Rio Negro near Manaus and the only available study that covers most of the length of the river is based on secondary forest succession inventories (Junk et al., 2010; Montero, 2012). Regarding palaeoecology, there is only one small area that has been studied to understand past vegetation and climate changes for the late Quaternary (Bush et al., 2004; Colinvaux et al., 1996; Cordeiro et al., 2011; D'Apolito et al., 2013; Santos et al., 2001). The Hill of Six Lakes showed that the northern part of the Amazon was very dynamic, reflected in an incomplete and complex palaeoecological record (Bush et al., 2004; D'Apolito et al., 2013). These results reported a cold period for times earlier than the Holocene, with the dominance of seasonal forest vegetation combined with cold taxa. Towards the late Holocene an increase of wetter conditions was detected and forest did not change drastically along the record.

Additionally, only few records have a complete Holocene sequence, and due to the fact that most of the lakes are originated by river dynamics, the probability to find a continuous record is very low (e.g. Bush et al.,2004; Behling et al., 2001; D'Apolito et al., 2013). However combining multi-proxy methods (geochemistry, charcoal, mineralogy etc.) to our pollen analysis have proven to be a useful tool for palaeoecological reconstruction in such fluvial dominated region (e.g. Bush et al., 2004; Irion et al., 2006; D'A polito et al., 2013; Rodríguez-Zorro et al., 2015). 
With this study we aim to contribute to detect the changes in vegetation, climate and possible human impact during the early and late Holocene in a highly dynamic floodplain of the middle-upper part of Rio Negro. A floodplain lake was analyzed using geochemical, pollen and microcharcoal analyses to test the responses of vegetation to the development and filling of the river together with climatic changes and possible human disturbances in the area. Our work is the first attempt to reconstruct the past vegetation changes and forest resilience directly from the middle-upper Rio Negro floodplain areas.

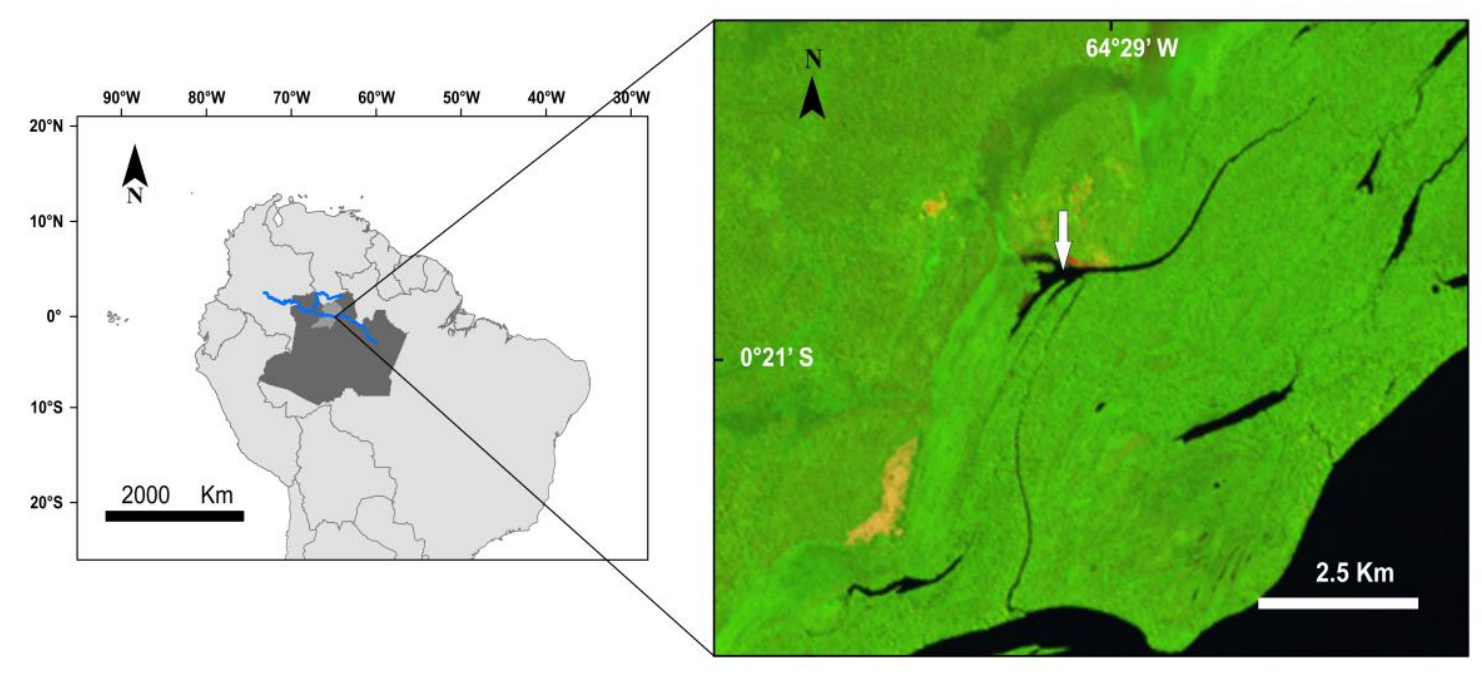

Figure 1 Location of the Lake Acarabixi sediment core. Left side, a map of South America including the Amazon region and the course of Rio Negro. Right side, Landsat 5 image showing the Lake Acarabixi. Black color is showing water courses and yellowish and reddish areas show open soils (sand dunes); green areas represent the Igapó forest. The white arrow is showing the coring site location.

\section{Study area}

The Lake Acarabixi is a flood plain lake in the middle-upper part of Rio Negro located ca. $60 \mathrm{~km}$ to the east of Santa Isabel do Rio Negro, in the Amazonia State in Brazil $\left(0^{\circ} 20^{\prime} \mathrm{S} 64^{\circ} 29^{\prime} \mathrm{W}, 33 \mathrm{~m}\right.$ elevation). The lake has an area of ca. $0.4 \mathrm{~km}^{2}$ and has a direct connection to the Rio Negro during extreme high water levels (Figs.1 and 2). The upper part of the Rio Negro possesses coarse sediments from Precambrian granitic and granulitic rocks of the Brazilian Shield and the alluvial landscape is characterized by rocky islands and the presence of granite inselbergs close to the river channel (Latrubesse and Franzinelli, 2005; Montero, 2012; Montero et al., 
2012). Latrubesse and Franzinelli (2005) have described the Rio Negro as a system with alluvial floodplains and a complex anabranching system, which can be divided into 6 main sections (Reaches) that have similar hydrologic characteristics within each section. The Lake Acarabixi is located in Reach II, where the anabranching pattern of the river begins in alluvial sediments that form a wide Holocene floodplain.

Santa Isabel do Rio Negro has a tropical equatorial climate (Af, Köppen classification) with a mean annual precipitation of $2500 \mathrm{~mm}$ and a mean annual temperature ranging between $25-28^{\circ} \mathrm{C}$ (INMET, 2016). The area has an increase of precipitation since March until August, followed by a rise in the levels of the river between May and August (Fig. 2). Subsequently, a period with a reduction of rainfall, not less than $100 \mathrm{~mm}$, occurs from September to February (ANA, 2016). Between January and March the river has the lowest levels, where sandy and quartzic banks are exposed.

The vegetation growing near the lake is Igapó forest, characteristic of black water rivers (Montero et al., 2012). The canopy height averages about 15-20 m with few emergent trees up to $30 \mathrm{~m}$. Woody lianas and palms are almost absent (Montero and Latrubesse, 2013). The most important families growing adjacent to the Rio Negro are Fabaceae, Lecythidaceae, Chrysobalanaceae, Euphorbiaceae and Sapotaceae. Other important families are Annonaceae, Malvaceae, and Rubiacae (Montero, 2012). 


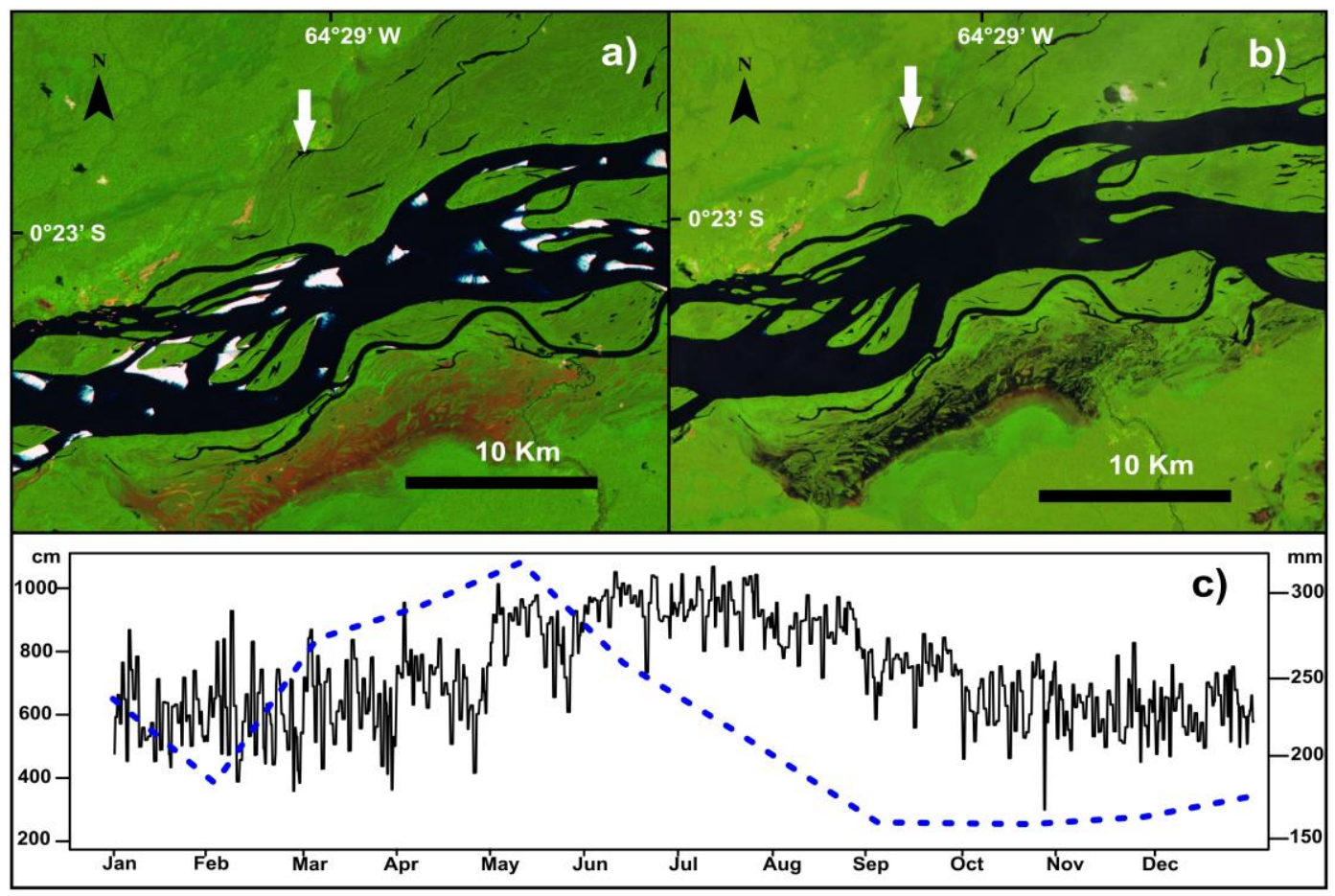

Figure 2 Hydrological variability between seasons at the middle-upper part of Rio Negro. a) Image from the Rio Negro and the Lake Acarabixi during the dry season on February 1985, showing the exposed soils (sands) due to the low water level. White arrow indicates the location of the lake. b) Image from the Rio Negro and the Lake Acarabixi at the end of the wet season on September1985. White arrow indicates the location of the lake. c) Mean monthly water level in cm (continuous line) from 1977 to 2015 (data courtesy of the Agência Nacional de águas (ANA 2016) at the climatic station Serrihna). Mean monthly precipitation in mm (dashed line) from 1961 to 1990 (data courtesy of INMET 2016 at the climatic station Santa Isabel do Rio Negro).

\section{Methods}

The sediments from the Lake Acarabixi were collected in 2002 by a vibra-coring system using aluminum tubes with a diameter of $7.6 \mathrm{~cm}$ and a platform based on two rubber boats. Two sediment cores were collected, ACA 02/03 $(330 \mathrm{~cm})$, which was used for our analyses and ACA 02/06 $(320 \mathrm{~cm})$. Nine bulk sediment samples were submitted to the Laboratoire de Mesure du carbone (LMC14), Saclay in France for ${ }^{14} \mathrm{C}$ AMS dating (Table 1). Radiocarbon dates were calibrated with the curve IntCal13 calibration curve for the northern hemisphere (Reimer et al., 2013) using the package 'clam' (Blaauw, 2010) in R ( $R$ Development Core Team (2016).The age depth model was developed with linear interpolation method. 
Bulk organic matter parameters were analyzed at the University of California Davis Stable Isotope Facility (USA). Total organic carbon (TOC) and total nitrogen were analyzed using an elemental analyzer (C/H/N FISONS NA-2000). Stable isotope composition $\left(\mathrm{d}^{13} \mathrm{C}\right)$ was analyzed using a Europe Hydra 20/20 mass spectrometer equipped with a continuous flow IRM. The analytical precision (as the standard deviation of repeated internal standard measurements) for the stable isotope measurements was $0.06 \%$ for $\partial^{13} \mathrm{C}$.

For palynological analysis 31 samples of $0.5 \mathrm{~cm}^{3}$ were analyzed from the core ACA 02/03. High content of sand on the record ACA 02/06 hampered the pollen analysis of the core. Samples were treated with $40 \% \mathrm{HF}$ and $10 \% \mathrm{KOH}$ following the standard method of Faegri and Iversen (1989). For calculation of pollen and charcoal concentration and influx one tablet of exotic marker was added (Lycopodium clavatum) per sample (Stockmarr, 1971). Pollen and spores identifications were based on reference literature (Colinvaux et al., 1999; Jiménez et al., 2008; Rangel-Ch et al., 2001) and the pollen reference collection at the Department of Palynology and Climate Dynamics (University of Göttingen, Germany).Most of the samples were counted to a sum higher than 400 pollen grains. The sample at $5 \mathrm{~cm}$ depth had very low pollen content and was counted to 90 pollen grains. Spores were excluded from the pollen sum. The zonation of the pollen diagram was obtained using CONISS on the pollen data (Grimm, 1987). The number of statistically significant zones was evaluated using the broken stick model (Bennett, 1996). The CONISS analysis was performed using the software TILIA (Grimm, 2015). Calculations and pollen diagram were done with Psimpoll (Bennett, 2009).

Pollen-based indices were calculated using R development core team (2016), version 3.3.1 and the vegan package, version (2.3.0) (Oksanen et al., 2015). The Pollen-spores sample diversity was plotted based on rarefaction analysis to a base of 10 counts $\left(E\left(\mathrm{~T}_{10}\right)\right)$ and pollen-spores richness using rarefaction to a base of 400 counts $\left(E\left(T_{400}\right)\right)$ using the method of Matthias et al. (2015).

Microcharcoal particles $(>10 \mu \mathrm{m})$ were counted on the pollen slides and expressed as concentration (particles/ $\mathrm{cm}^{3}$ ) and influx (particles/ $\mathrm{cm}^{2} / \mathrm{yr}$ ). 
Table1. List of the AMS radiocarbon dates from the Acarabixi sediment core ACA 02/03.

\begin{tabular}{lllll}
\hline Depth (cm) & Lab-code & Dated material & ${ }^{14}$ C yr BP & $\begin{array}{l}\text { Age cal yr } \\
\text { BP(weighted } \\
\text { average, 2 } \sigma)\end{array}$ \\
\hline 10 & SacA3280 & Bulk sediment & $945 \pm 40$ & $741-883$ \\
39 & SacA3281 & Bulk sediment & $1615 \pm 40$ & $1337-1489$ \\
45.5 & SacA3282 & Bulk sediment & $7410 \pm 60$ & $7741-7937$ \\
75 & SacA3283 & Bulk sediment & $8750 \pm 80$ & $9118-9469$ \\
98 & SacA3284 & Bulk sediment & $8810 \pm 70$ & $9145-9653$ \\
143 & SacA3285 & Bulk sediment & $9100 \pm 70$ & $9676-9919$ \\
200 & SacA3286 & Bulk sediment & $9370 \pm 70$ & $9856-10,226$ \\
$247.5^{*}$ & SacA3287 & Bulk sediment & $9010 \pm 60$ & $9560-9697$ \\
327 & SacA3288 & Bulk sediment & $9480 \pm 70$ & $10,133-10,401$ \\
\hline
\end{tabular}

*Date not included in the age depth model

Landsat 5 images were obtained from the web page of the Brazilian National Institute for Space research (INPE, 2016). These color images are composed of the mid infrared band 5, the near infrared band 4 and the red band 3. The composed image was used to show land water boundaries.

\section{Results}

\subsubsection{Stratigraphy and chronology}

Sediments of the Lake Acarabixi are characterized by the dominance of sandy and silty deposits with a few fraction of clay (Figs. 3 and 4). The sediments have a mixture of organic fragments, composed mainly by leaves and wood remains (Table 1). Coarser sediments are found at the bottom and top of the core. The record has a gap in sediments between 145 and $176 \mathrm{~cm}$ as a result of the retrieving process of the core. 
Table 2. Description of the sediments of the Lake Acarabixi core ACA 02/03.

\section{Core depth (cm) Description of sediments}

0-30 Medium size sandy sediments with abundant leaf and bark fragments.Some fragments of charcoal ( $3 \mathrm{~mm}$ diameter) are observed at $16 \mathrm{~cm}$

30-40 Silt-sand sediments with a small fraction of clay. There is an increase on bark fragments. Leaves are fragmented in smaller pieces.

40-47 Light grey clay sediments with a small fraction of fine sand. Leaf and bark fragments are reduced

47-75 Light gray silty and fine grain sandy sediments with a small fraction of leaf and bark fragments. At $61 \mathrm{~cm}$ are observed some charcoal fragments (1-3 $\mathrm{mm}$ )

75-95 Dark organic Silt-clay sediments full of leaf and bark fragments

95-135 Silty sediments with and increase on sand. Small proportion of leaf and bark fragments

135-142 Sandy sediments with fragments of leafs and bark

142-176 Loss of sediments

176-223 Fine sandy sediments with abundant small fragments of leaves and bark. Sand size is increasing toward the bottom

223-260 Sandy sediments. Leafs and bark fragments are getting reduced toward the bottom. Quartz and mica are observed at 240 and $260 \mathrm{~cm}$.

260-302 Coarse to mid sandy sediments with few leaf and bark fragments

302-330 Coarse sandy sediments 


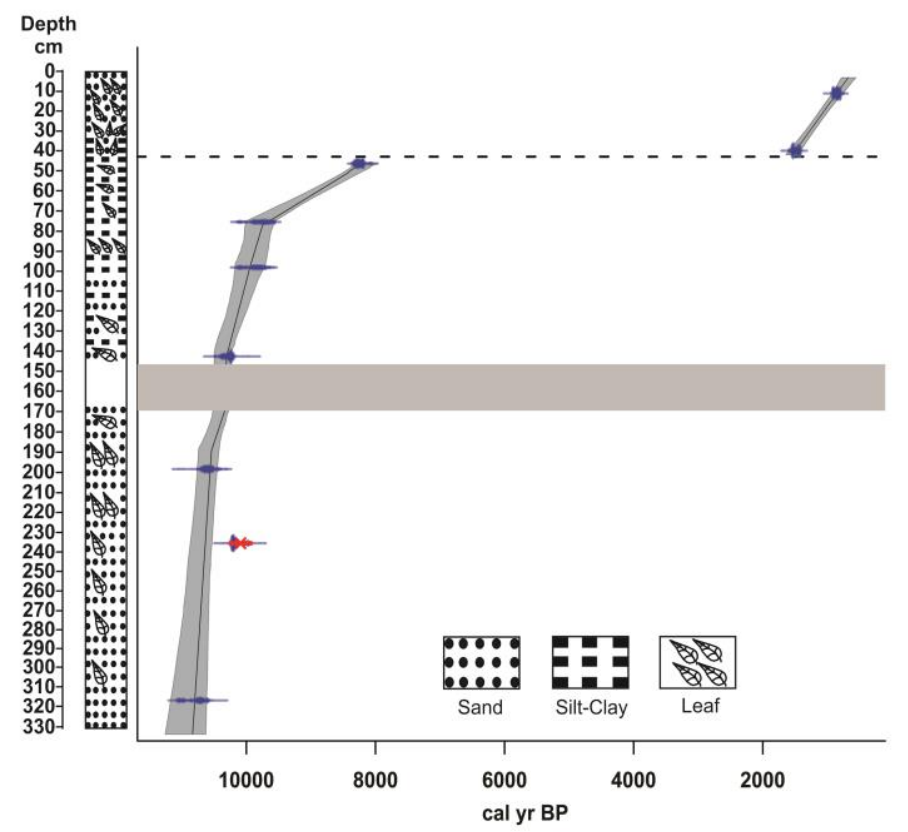

Figure 3 Stratigraphy and chronology of the Lake Acarabixi sediment core. The stratigraphy is shown on the left side. Dashed line indicates the hiatus in sedimentation and the followed thick gray band indicates a gap between sediments.
The age depth model used for this paper is based on eight of the nine radiocarbon dates from the record ACA 02/03 (Table 1 and Fig. 3). The date at $245.5 \mathrm{~cm}$ depth was rejected as a result of reworked material. A slump was added between 176 and $145 \mathrm{~cm}$. The model showed ages spanning from 10,840 cal yr BP to $650 \mathrm{cal}$ yr BP. A hiatus in sedimentation was detected from 8240 to 1600 cal yr BP (44 $\mathrm{cm})$. Therefore, the periods analyzed in this manuscript are related to part of the early Holocene from 10,840 to 8240 cal yr BP and part of the late Holocene from 1600 to $650 \mathrm{cal} \mathrm{yr} \mathrm{BP.}$

\subsubsection{Geochemical record}

Geochemical analyses showed an increase on the percentage of $C$ toward the top of the core (TOC) (Fig. 4). The highest peak on total carbon content (TOC) is at $80 \mathrm{~cm}$ (14.9\%). Carbon accumulation rate has the highest peaks between 250 and $197 \mathrm{~cm}$ depth (160 and $210 \mathrm{~g} / \mathrm{m}^{2} / \mathrm{yr}$ ) and it decreases toward the top of the sediment core. The $\delta^{13} \mathrm{C}$ values are higher at the bottom part of the core, with a maximum at 304 $\mathrm{cm}(-20.7 \%)$. Afterwards, values are reduced toward the top, oscillating between 31 and $-27 \%$. C/N curve showed a variation between 40 and 70 .

\subsubsection{Pollen diagram}

The samples at the core depths 262, 282, 314 and $330 \mathrm{~cm}$ lacked pollen. The sample at the core depth of $5 \mathrm{~cm}$ was not included for interpretation as a result of lower pollen content in the sample (90 pollen grains). The pollen record of ACA 02/03 was divided in 4 zones: A1 (302-210 cm; 7 samples), A2 (210-81cm; 7 samples), A3 
(81-44cm; 5 samples) and A4 (44-0 cm; 10 samples). A total of 98 pollen types were identified and grouped into 5 ecological groups: Lowland forest, lianas, palms, herbs and highland (Figs. 5 and 6). Pollen concentration oscillates between 3000 and 140,000 grains $/ \mathrm{cm}^{3}$ and pollen influx between 300 and 32,700 grains/ $\mathrm{cm}^{2} /$ year. Pollen-spores sample diversity $\left(\mathrm{E}\left(\mathrm{T}_{10}\right)\right)$ has the highest values from $42 \mathrm{~cm}$ depth toward the top. Pollen-spores richness $\left(\mathrm{E}\left(\mathrm{T}_{400}\right)\right)$ has the highest values from 35 to 26 cm core depth (Fig. 6). As rarefaction to low counts $\left(\mathrm{E}\left(\mathrm{T}_{10}\right)\right)$ as a diversity indicator (Matthias et al., 2015) has not been tested in this kind of ecosystem, we have also applied Shannon index (Hill,1973) to our samples for comparison (data not shown). The results are highly correlated $\left(R^{2}=0.9238\right)$, thus we have selected the representation for diversity as rarefaction to a base of 10 counts $\left(E\left(\mathrm{~T}_{10}\right)\right)$ as a conceptually simpler representation of pollen type diversity within the sample. Microcharcoal concentration and influx have the highest peak at $200 \mathrm{~cm}$ core depth.

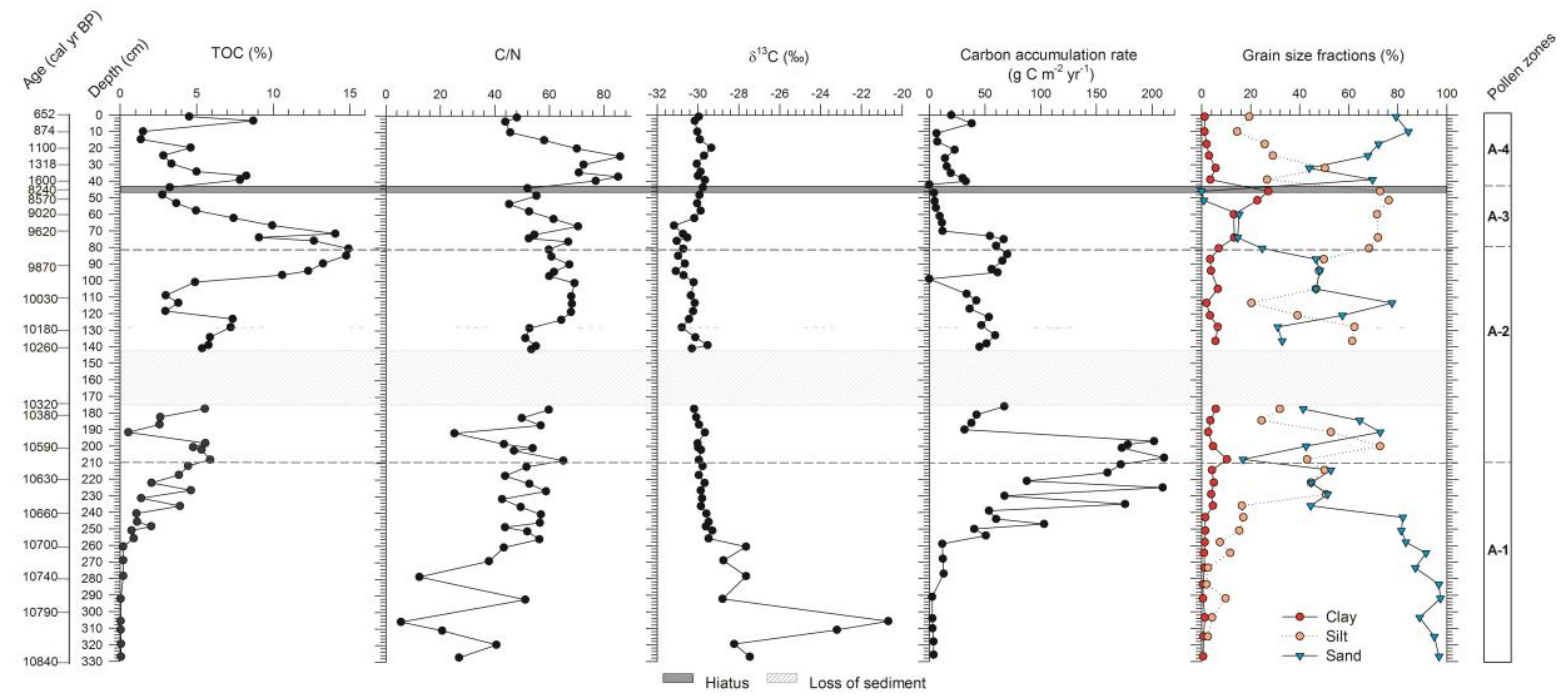

Figure 4 Geochemical data of the Lake Acarabixi record showing the Total Organic Carbon (TOC), atomic $\mathrm{C} / \mathrm{N}$, the isotopic $\delta 13 \mathrm{C}$, the carbon accumulation rate and the grain size fractions of the sediment.

\subsubsection{Pollen zone A1 (302-210 cm; 10,790-10,600 cal yr BP; 7 samples).}

The main characteristic of this zone is the low pollen concentration at the lowest part of the core (302 to $241 \mathrm{~cm}$ ) with values oscillating between 3400 and 4600 grains $/ \mathrm{cm}^{3}$. Values increase toward the end of the zone. The highest representation of highland taxa (0-3\%) is within this zone. Myrsine and Hedyosmum are found at 
$302 \mathrm{~cm}$ with values of $0-2 \%$. The ecological group of herbs has also the highest representation with values between 6-11\%. Lowland vegetation dominates (6486\%) with taxa such as Alchornea/Aparisthmium (9-12\%), Moraceae/Urticaceae (7$21 \%)$, Melastomataceae (3-12\%) and Cecropia (2-11\%). The lowest values of Mabea are found in this zone; it starts to increase at $240 \mathrm{~cm}$ with values between 1 and $7 \%$. The second representative group of this interval is the lianas (4-16\%). The genus Dicranostyles (1-10\%), Banisteriopsis (1-5\%) and Rhamnaceae $(0-1 \%)$ are the most characteristic taxa. Toward the end of this period values of lianas are getting reduced. Pollen from palms has an increase on their representation toward the end of the zone at $221 \mathrm{~cm}(8 \%)$, mainly dominated by Astrocaryum with values of $7 \%$. Herbs have the highest percentages of the record $(11 \%)$, mainly dominated by Cyperaceae (2-3\%) and Poaceae (1-6\%) taxa.

\subsubsection{Pollen zone A2 (210-81cm; 10,600-9770 cal yr BP; 7 samples).}

The main characteristic of this interval is the increase of pollen-spores richness compared to the previous zone. Pollen concentration also increases and has values between 66,000 and 30,700 grains $/ \mathrm{cm}^{3}$. Pollen influx has the highest values of the record at $201 \mathrm{~cm}\left(32,700\right.$ grains $/ \mathrm{cm}^{2} /$ year). Highland taxa are not well represented only at $181 \mathrm{~cm}$ depth $(0.3 \%$ of Myrsine). Lowland vegetation dominates this zone (84-89\%). New taxa occur like Sebastiania (0-4\%), Amanoa (1-3\%), Tabebuia type (0$1 \%)$, Casearia type $1(0-2 \%)$ and Guarea $(0-5 \%)$, while others increase their frequencies such as Swartzia (4-11\%), Mabea (10-21\%), Casearia type 2(0-5\%) and Myrtaceae (2-8\%). AlchornealAparisthmium has the highest frequencies of the record between 176 and $130 \mathrm{~cm}$ depth (16-15\%); afterwards, it is reduced toward the end of the interval. Lianas have frequencies of $4-6 \%$, palms $2-4 \%$ and herbs $0-1 \%$. In this zone microcharcoal has the highest concentration of the record at $200 \mathrm{~cm}$ depth $\left(32,200\right.$ particles $\left./ \mathrm{cm}^{3}\right)$. Towards the top the values are reduced (5300 and 1500 particles $\left./ \mathrm{cm}^{3}\right)$.

Pollen zone A3 (81-44cm; 9770-8240 cal yr BP; 9 samples). Pollen concentration is the highest of the record $\left(114,000-140,000\right.$ grains $\left./ \mathrm{cm}^{3}\right)$. Lowland forest vegetation dominates this period (89-83\%). Sebastiania pollen increases markedly (12-22\%). Some forest taxa are slightly reduced as Swartzia (1-3\%) and Myrtaceae (0-3\%) but others are increasing as Annona (0-2\%), Guarea (1-3\%). Palm pollen (2-8\%) has a slight increase toward the end of this zone. Pollen-spores sample diversity has the 
lowest values of the record at the depth of $45 \mathrm{~cm}$. Myrsine was present but with low frequencies $(0.3 \%)$.

\subsubsection{Pollen zone A4 (44-0 cm; 1600-650 cal yr BP; 6 samples).}

A significant change of vegetation for zonation is found at $44 \mathrm{~cm}$ depth, where the hiatus in sedimentation occurred. Pollen concentration is getting reduced toward the top (2000-88,000 grains/ $\left.\mathrm{cm}^{3}\right)$ and pollen influx is the lowest of the record (3004000 grains $/ \mathrm{cm}^{2} /$ year). Pollen-spore sample diversity increases and has the highest values of the record as well as richness. Forest pollen dominates and is oscillating through this interval $(81-90 \%)$. Several forest taxa increase their percentages toward the top from the depth of $42 \mathrm{~cm}$ as Swartzia (4-5\%), Sapotaceae (1-3\%), Ferdinandusa (0-2\%), Myrtaceae (1-6\%), Ormosia (2-8\%), Shefflera (0-2\%), Amanoa (1$4 \%)$ among others. Pioneer taxa are present in this interval as Vismia (1-4\%) and Cecropia (1-4\%). Annona and Guarea are not represented toward the top. Sebastiania pollen $(0-9 \%)$ decreases toward the top of the core. Lianas $(2-9 \%)$ show a moderate increase, dominated by Dicranostyles (1-4\%). Microcharcoal concentration oscillates between 6,000 and 55,000 grains $/ \mathrm{cm}^{3}$. The highest values are observed at $35 \mathrm{~cm}$ depth. 


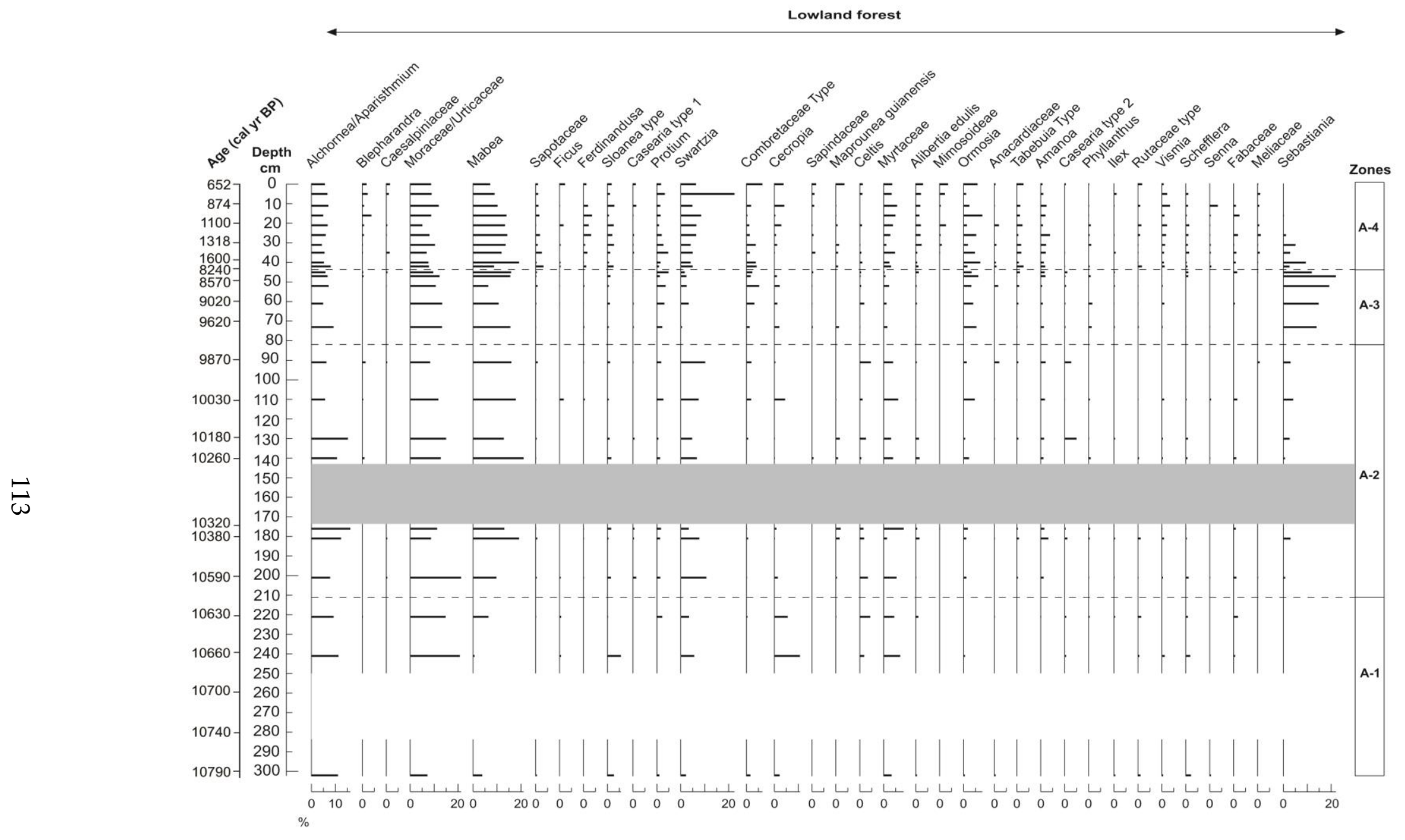

Figure 5 Pollen and spores percentage diagram showing the taxa grouped into ecological groups: Lowland forest, lianas, palms, herbs and highland taxa $(\mathrm{HT})$. The grey line show the gap in sediments and the white line indicate samples without pollen content. 


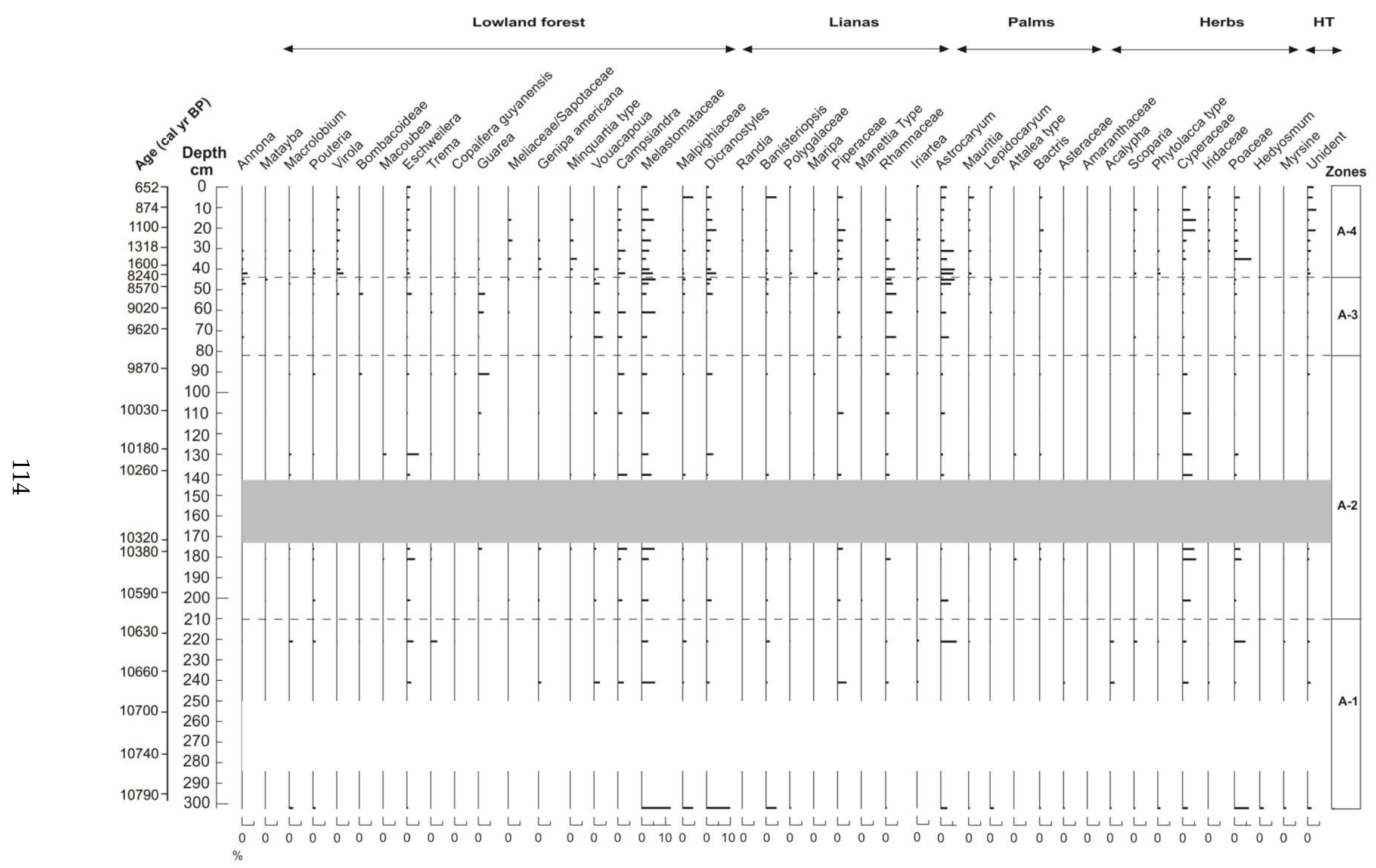

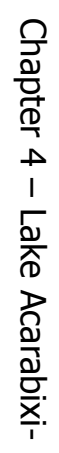




\section{Interpretation and discussion}

\subsubsection{Geochemical record}

The geochemical and sedimentological data from the Lake Acarabixi showed the development and dynamics of the lake during the early and late Holocene. Different phases of stability and river flux pulses were detected in the lake (Fig. 4). The dominance of coarse to medium sands, together with the reduced values of carbon (TOC and carbon accumulation rate), revealed a more dynamic environment in the Lake Acarabixi from 10,840 to 10,660 cal yr BP (330 to $240 \mathrm{~cm}$ core depth). At that time the lake had a direct influence of water flux coming from a Rio Negro channel. This effect was also visible in the variable bulk organic matter values of $\mathrm{C} / \mathrm{N}$ and $\mathrm{d}^{13} \mathrm{C}$. On the other hand, the high values of $\partial^{13} \mathrm{C}$ at that time may indicate the influence of grasses growing on the banks during the low water season (Martinelli et al., 2003; Meyers, 2003).

At 10,660 cal yr BP $(240 \mathrm{~cm})$, probably due to lateral channel migration, although the sedimentation was still sandy, it became richer in silt and organic matter, corresponding to a shallower part of the banks with less energy from the river channel (Fig. 4). At that time, the organic matter had low ${ }^{13} \mathrm{C}$ and high $\mathrm{C} / \mathrm{N}$ values which may indicate an organic matter origin from the Rio Negro podzols and their humic substances production and/or from the Igapó forest organic matter degradation. The fining-up sequence from the base of the core to $45 \mathrm{~cm}$ depth (8240 cal yr BP) is in agreement to a channel-point bar migration system. Sedimentation rate was still high during the early Holocene indicating that the filling of the valley was sustained by the Rio Negro sediment supply until ca. $8240 \mathrm{cal}$ yr BP. The sedimentation rate began to slow down around $8970 \mathrm{cal}$ yr BP $(60 \mathrm{~cm})$ when the last facies of the sequence (clayey silt sediments) deposited (Figs. 3 and 4). Then the deposition of sediments coming from Rio Negro stopped, probably because of the migration of the river channel from the Lake Acarabixi, possibly near its present day position.

This development of the Lake Acarabixi sediments is in agreement with the interpretation of the Rio Negro valley filling from upstream to downstream reaches of Latrubesse and Franzinelli (2005). Therefore, the reach where the Lake 
Acarabixi is located (reach II) seems to have been filled almost completely around 8000 cal yr BP.

The presence of the hiatus between 8240 and 1600 cal yr BP could be explained as an effect of the evolution and filling of the Rio Negro, which was reflected in lateral erosion and active deposition in the lake (Latrubesse and Franzinelli, 1998). Such dynamics were detected in the sediments of the core ACA 02/06 (data not shown) which contain organic detritus in between of thick sandy layers for the period where ACA02/03 has the hiatus in sedimentation.

After the hiatus in the sedimentation, the deposition of sediments resumed at ca. 1600 cal yr BP with silty coarse to medium sands very rich in leaves and bark fragments. The bulk organic matter had very high $\mathrm{C} / \mathrm{N}$ values. The $\mathrm{C} / \mathrm{N}$ values and the low ${ }^{13} \mathrm{C}$ probably indicate an influence of organic matter degradation coming from the Igapó forest in the surroundings of the lake and its tributaries. This period, showed an aquatic environment permanently flooded that allowed the preservation of organic matter corresponding to a wetter phase since $1600 \mathrm{cal} \mathrm{yr}$ BP. Intense discharge events must occurred to supply the lake with coarse to medium sands from the small present-day tributaries.

\subsubsection{Pollen record}

\subsubsection{Period I (10,790-10,600 cal yr BP; zone A1).}

In this period, the direct influence from the Rio Negro into the Lake Acarabixi was reflected in the low pollen accumulation and vegetation arrangements (Figs. 5 and 6). The lowest pollen sample of the Lake Acarabixi record ( $302 \mathrm{~cm} ; 10,790 \mathrm{cal} \mathrm{yr} \mathrm{BP})$ showed that lowland forest taxa dominated, but the forest was more open compared to recent times. The presence of herbs such as Cyperaceae and Poaceae along with frequent lianas indicated a period with strong dynamics that favored open forest with herbs. As shown in the Figure 2, the Rio Negro can experience low water levels during the period of reduced rainfall (September to February). Therefore, it is likely that for the early Holocene longer dry periods occurred, thus producing more exposed areas that allowed herbs to grow together with a more open canopy. Nowadays, the presence of terrestrial and aquatic herbs is very rare in black water systems, especially in many river channels with large sandy beaches 
there is not herbaceous vegetation (Junk et al., 2011). However, our pollen data along with the isotopic signal of $\delta^{13} \mathrm{C}$ confirmed suitable areas for herbs to grow (Figs. 4 and 6). In other records along the Amazon, it was reported that around this time the location of the ITCZ was placed in a southernmost position, which could alter the quantity of precipitation in the region and therefore the flooding regime of the river (Cheng et al., 2013) (see below the climatic setting). Additionally, at that time, the presence of high altitude taxa as Myrsine and Hedyosmum may indicate still cooler conditions from previous times (Bush et al., 2004; D'Apolito et al., 2013). Such taxa may have come from the neighboring mountains Pico Neblina $(220 \mathrm{~km})$ or Serra Imeri $(120 \mathrm{~km})$ or simply grown in the surroundings as it was described in other lowland records (Van der Hammen and Hooghiemstra, 2000).

After 10,660 cal yr BP $(240 \mathrm{~cm})$ the forest expanded and subsequently reduced, reflecting a recovery after a lateral migration from a channel from the Rio Negro. At this time the highest pollen- spores sample diversity and richness occurred. The highest values on the record of Cecropia and Trema indicated a vegetation recovery after disturbances. Cecropia is well known as shadow intolerant species and colonizer of open and disturbed areas (Bush and Colinvaux, 1988; Ledru, 2001; Rodríguez-Zorro et al., 2015). Additionally, at that time Astrocaryum palm trees were growing in the study site. Nowadays, the Astrocaryum jauari is a very common palm along the Rio Negro flood plains (Piedade et al., 2006). This palm develops in riverbanks and islands and tolerates floods between 30 and 340 days, being very plastic to changes in environmental conditions. Those palms produce flowers when rivers have low levels and precipitation is reduced (Piedade et al., 2006). Assuming that our taxon is also mostly entomophilous pollinated as other species from the Astrocaryum genus (Oliveira et al., 2003; Ramos et al., 2016), we could hypothesize that the palm was abundant and it grew on the shores of the lake in a period with longer low water stands. 


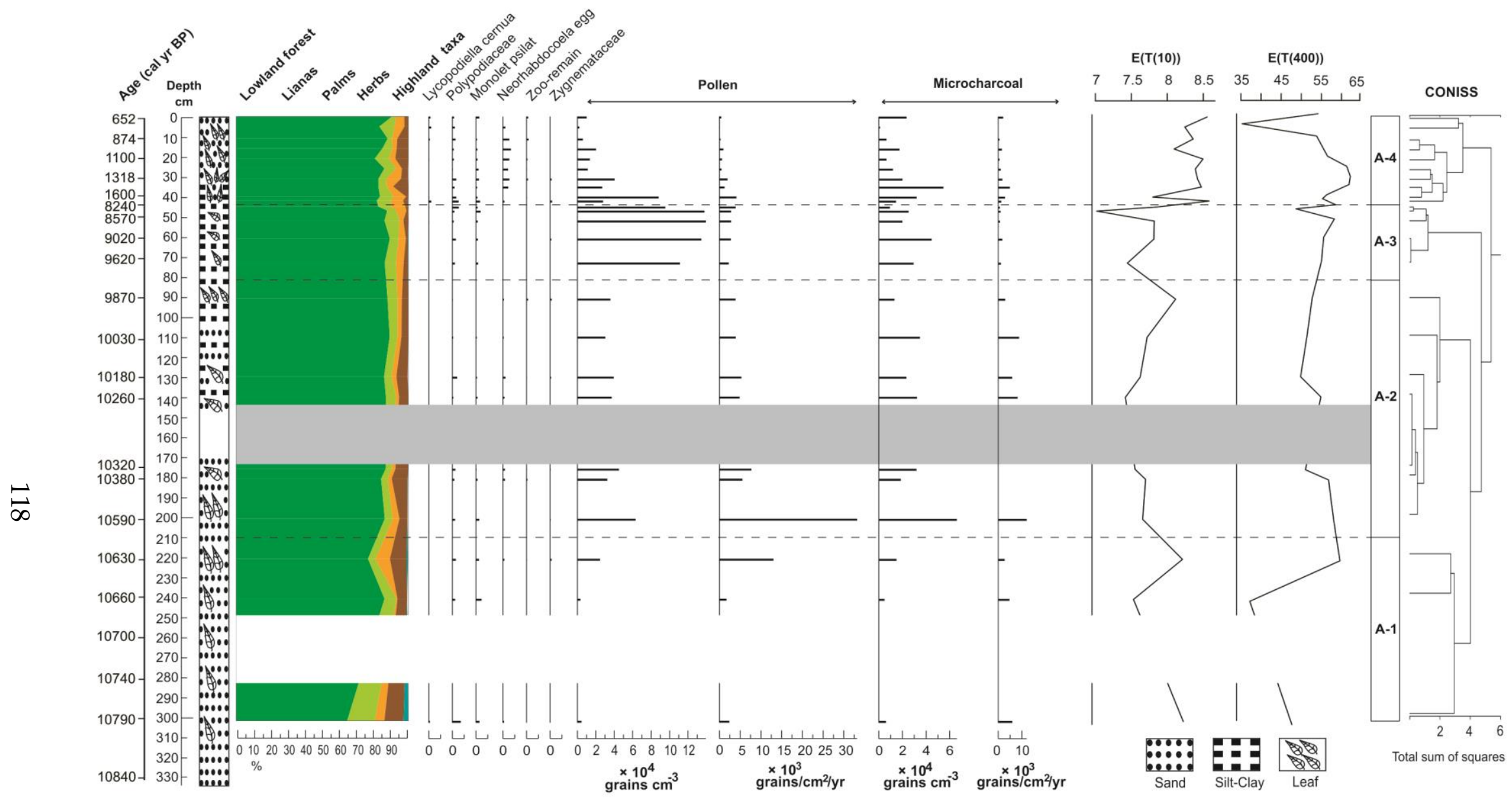

Figure 6 Pollen sum diagram showing the sum of each ecological group, spore percentages, pollen and microcharcoal concentration, pollen and charcoal influx, pollen-spores sample diversity E(T10) and pollen-spores richness E (T400). The grey line show the gap in sediments and the white line indicate samples without pollen content. 


\subsubsection{Period II (10,600-9770 cal yr BP; zone A2).}

This period was characterized by more lacustrine phases. The reduced influence from the Rio Negro allowed highest maxima of carbon accumulation rate and pollen influx at 10,580 cal yr BP $(200 \mathrm{~cm})$. The frequency of lianas and herbs were reduced toward the end and lowland forest dominated the whole period. Species that are tolerant to long periods of flooding were more abundant such as Swartzia, Eschweilera and Mabea (Montero, 2012). The reduction of Cecropia and Trema may indicate a forest that recovered from the dynamics in the previous interval.

The microcharcoal record showed an increase on regional fire events after the lake had less influence from the river channel (since ca.10,660 cal yr BP) (Fig. 6). Such regional signal could be linked to extreme dry years in the area, as reported for the upper part of the Rio Negro igapó forests (Saldarriaga and West 1986; Clark and Uhl, 1987). In addition, the work from Flores et al. (2014) showed that fires are frequent in the middle Rio Negro floodplain forests when long dry periods occur as well. In the floodplains of Barcelos, a City $200 \mathrm{~km}$ downstream from Lake Acarabixi, several fires that occurred in the 1990's as a result of longer periods of the dry season. This study revealed that more than 75 percent of tree mortality and 90 percent of the superficial root system were lost after fire, thus favoring the invasion of herbaceous vegetation (Flores et al., 2014, 2016). Consequently we could hypothesize that Lake Acarabixi was not subject to local fires as forest vegetation was dominant, but instead, was reflecting the effect of a long dry period in the surroundings. Other palaeocological studies in the Gran Sabana in Venezuela and Roraima in Brazil have reported dry periods with high fire signal for this time (Rull et al., 2015; Simões Filho et al., 2010). However, to understand the fire dynamics in such floodplains more palaeoecological records including charcoal analyses are needed.

\subsubsection{Period III (9770-8240 cal yr BP; zone A3).}

The last phase reflected the filling of the Lake Acarabixi. Lacustrine phases were detected by the highest pollen accumulation rates of the record and fine texture in the sediments. The lowland forest dominated and a swamp of palms developed in the surroundings with the presence of Astrocaryum, Iriartea and few Mauritia palm trees. Herbs decreased as a result of the increase of flooded areas. At this time, Sebastiania was reported with the highest vegetation cover in the record, which 
may indicate a more dynamic environment in the surroundings of the lake. The presence of Sebastiania since the last interval (since ca. 10,580 cal yr BP) and the marked increase in this period is striking, since this genus has not yet been reported in the amazon region in Brazil (REFLORA, 2016). The morphology of this pollen grain has been placed at the genus Symmeria in past palaeoecological reconstructions in the Amazon region (Absy,1979; Behling et al., 2001), but after literature and reference collection research, it is more probable that this pollen grain belongs to one of the taxa that are included into the tribe Hippomaneae, where Sebastiania is located (Absy, 1979;Colinvaux et al.,1999; Correa et al., 2010; Sales et al., 2011; reference collection at the Department of Palynology and Climate Dynamics, Göttingen-Germany). As the taxonomy of the Hippomaneae tribe is not yet clear, we are not certainly sure of the plant origin of our pollen grain (AthiêSouza et al., 2015; Esser, 2012). To corroborate that such genus grows in the area and therefore strengthen our interpretation, more vegetation surveys together with a clear taxonomic classification are needed.

\subsubsection{Period IV (1600-650 cal yr BP; zone A4).}

After the hiatus in sedimentation at 8240 to $1600 \mathrm{cal}$ yr BP changes in pollen and charcoal concentration were reflected (Fig. 6). Pollen-spores sample diversity and richness had a slight decrease and afterwards a sudden increase, which showed the new arrangements of vegetation for the late Holocene. After $1600 \mathrm{cal}$ yr BP no drastic changes in vegetation occurred, but a decrease in pollen concentration was observed. The latter can be related to the new input of sediments into the lake that came from the tributaries in the surroundings (Fig. 4). In despite of the low pollen concentrations, the pollen signal showed a permanently flooded environment, where several Igapó forest species were dominant (e.g. Mabea, Swartzia, Eschwilera, Alibertia edulis etc.) (Montero, 2012). An increase on the palms Astrocaryum, Iriartea and Mauritia may indicate also a wetter environment.

In addition, disturbances in the area might be reflected by the presence of Vismia and Cecropia trees (Mesquita et al., 2015). The constant presence of these two pioneers in the area could indicate that the forest was cleared, as these plants grow very fast after continuous pruning or fires (especially Vismia) (Mesquita et al., 2015). In our record, regional fires were detected, as also reported in several parts of the Amazon at that time (e.g. Berrio et al., 2002; Meneses et al., 2013; Rull et al., 
2013). Most of the fires in such studies were attributed to humans. In our study site a human made fire signal might not be evident unless the vegetation cover is low and the canopy is open, which is not reflected in our results. Moreover, human made fires for agriculture might not have occurred since the Igapó forests are not suitable for agriculture due to the seasonal flooding (Clark and Uhl, 1987). However, fires can be produced by fisherman and they could be the main source of ignition during dry years (Ritter et al., 2012). Our sediments showed that for the late Holocene, some fragments of charcoal were deposited in the Lake (Table 2), probably indicating local fires since $1450 \mathrm{cal}$ BP $(30 \mathrm{~cm})$. Such particles were simultaneously occurring with Vismia which therefore may indicate that humans were already in the area.

\subsubsection{Climate and Regional Vegetation Changes}

\subsubsection{Early Holocene}

For the early Holocene our data reflected a more seasonal period with dry climatic conditions as proposed by several palaeoecological records at the north of South America (e.g. Behling and Hooghiemstra, 2000; Cheng et al., 2013; Rull et al., 2013). Speleothem records had detected dry conditions for the western part of the Amazon due to the diminution on convective moisture from the Atlantic, which was reflected in a weak SAMS at that time (Cheng et al., 2013; Vuille et al., 2012). In the region where the Lake Acarabixi is located, the influence of the ITCZ combined with the flux of moisture coming from the SAMS were the main factors that determined whether a longer or shorter dry period occurred (Cheng et al., 2013; Vuille et al., 2012). As the ITCZ had a longer incursion toward the south at that time; besides a weak signal from the SAMS, the early Holocene in the Lake Acarabixi reflected a variable period with reduced precipitation.

Such climatic conditions therefore played a role in vegetation arrangements in the Amazon Basin. In the Lake Acarabixi, geochemical and palynological data indicate that a drier period than recent times occurred and more open forest along with herbs grew in the area (Figs 5 and 6). Our results are in similar with those found at the Hill of Six Lakes at ca. $300 \mathrm{~km}$ north-west from the Lake Acarabixi (Bush et al., 2004; Colinvaux et al., 1996; Cordeiro et al., 2011; D'Apolito et al., 2013; Santos et al., 2001). The main findings for the early Holocene at the Hill of Six Lakes 
according to the new revisited version from D'Apolito et al. (2013) showed that this period had a more seasonal climate, reflected in a lower level of the lake compared with recent times. The lake had higher discharge variability and more flood energy with sediment accumulation rates that were getting reduced toward more recent times. In the Lake Acarabixi record was also reflected a more seasonal period with a high input of coarse sediments as a result of the filling of the Rio Negro valley together with a more seasonal climate (Fig. 4) (Latrubesse and Franzinelli, 2005). Our data indicated that although forests were dominant along the record, a different vegetation composition with more open forests and herbs prevailed for the early Holocene (Figure 5).

In a regional point of view, a dry early Holocene was detected in different records located at the north of the Amazon Basin. At the northwest in the Caquetá Basin in the Colombian Amazon, the record from Behling et al. (1999) showed that at the early Holocene there were lower water levels and lower rainfall, reflected in a smaller swamp. For the forest-savanna mosaics in the Llanos Orientales in Colombia similar climatic and vegetation changes were reported. At Loma Linda record (Behling and Hooghiemstra, 2000), the early Holocene landscape was dominated by grass savanna and gallery forests were limited. The authors also suggested a reduction in the annual precipitation or a longer annual dry season than today. Similar trends occurred at Laguna Angel and Sardinas were the greatest expansion of grassland savannas occurred (Behling and Hooghiemstra, 1998, 1999). Moreover, savannas of the Gran Sabana in Venezuela and Roraima in Brazil also showed a replacement of forest by savanna during the early Holocene, apart from an increase on fires (Gran Sabana Venezuela) (Rull et al., 2015; Simões Filho et al., 2010). The increase on regional fires at that time might be also registered in the Lake Acarabixi.

Conversely to these changes on the north and northwestern part of the Amazon Basin, the south eastern part of the basin had wetter climates with the dominance of forest vegetation, high water level, low fire activity and organic matter accumulation for the early Holocene (Absy et al., 1991; Hermanowski et al., 2014; Hermanowski et al., 2012a, 2012b; Sifeddine et al., 2001). 
In all these records the effect of the ITCZ together with the SAMS and local geomorphological features allowed forest expansion or retraction (openness) depending on the location of the studied sites.

\subsubsection{Late Holocene}

Climatic conditions for the late Holocene where wetter due to a more northerly position of the ITCZ, which brought more intense rainfall in the studied area (Apaéstegui et al., 2014). The variation in texture and sedimentation rates of sediments in Lake Acarabixi indicated a variable period in which forest vegetation was adapted since the early Holocene.

Recent studies in the Amazon forests showed that the effect of the changes on the dry season length influences strongly the ecosystems resilience. The effect of water stress combined with spatial variation in soil texture will be reflected on variation in ecosystem biomass, composition and dynamics (Levine et al., 2016). In the case of the middle-upper part of the Rio Negro, such effect on forest resilience to changes on dry season length was observed. The forest that was adapted to a longer dry period in the early Holocene started to rearrange and adapt to a more humid environment towards the late Holocene.

For the late Holocene, fire signal was reduced (microcharcoal influx), indicating an increase on wetter conditions compared with the observed high regional fire frequencies in the early Holocene (Fig. 6). On the other hand, in the Lake Acarabixi, there was not clear evidence that showed agricultural activities or human made fires in the surroundings as shown in other studies in the Amazon Basin for this period (Berrio et al., 2002; Bush et al., 2007; Meneses et al., 2013; Rull et al., 2013; Cordeiro et al., 2014). In the area, a human activity or disturbance could be attributed to an increase of herbs and the presence of pioneers such as Vismia together with the increase of small pieces of charcoal (Table 2). However, little is known about the history of indigenous people living along the Rio Negro Basin especially close to our studied area. For the upper part of the Rio Negro at the Colombian and Venezuelan border, Saldarriaga and West (1986) found pottery pieces that dated to $3750{ }^{14} \mathrm{C}$ yr BP which might indicate people living in the area since the mid-Holocene. 


\section{Conclusions}

For the early and late Holocene, the Lake Acarabixi is interpreted as a highly dynamic floodplain lake, in which vegetation was resilient to changes to the amount of precipitation and the filling dynamics of the valley of the Rio Negro. Our record shows the development of a flood plain lake that was subject to a direct influence by a channel from the Rio Negro, which changed afterwards to a lake with more lacustrine phases.

The Lake Acarabixi sediments showed two main climatic changes with forest dominance. 1) A drier early Holocene from 10,840 to 8240 cal yr BP where more open forests with herbs developed and 2) A wetter late Holocene environment from 1600 to $650 \mathrm{cal} \mathrm{yr} \mathrm{BP}$ in which species were more tolerant to longer periods of flooding; both in agreement with other palaeoecological records in northern South America.

The main finding of our record was the forest resilience to climatic and local disturbances for the early and late Holocene. The extreme conditions of the Rio Negro black water river modeled the plasticity of forest species through the Holocene. In this context, vegetation had to adapt to environmental changes coming from different climatic and geomorphological factors in the study area such as the low nutrients content, the dominance of quartz sediments, and the extreme changes on water flux between low and high river stands.

Our work strongly invites the scientific community working on Amazon ecosystems to contribute on the understanding of human cultures, vegetation and ecology in the studied area.

\section{Acknowledgments}

This research was funded by IRD/CNPq convention, LMI PALEOTRACES 2 and ANR BELMONT PACMEDY. The DAAD-COLFUTURO scholarship is thanked for funding the first author. We are grateful to the Laboratoire de Mesure du carbone (LMC14), Saclay in France for the AMS dates; Enrique Moreno and Daiana Fontes (Smithsonian Tropical Research Institute, Panamá) for helping on pollen identification; Thomas Giesecke and Vincent Montade (Georg-August University Göttingen, Germany) for stimulating discussions. 


\section{References}

Athiê-Souza, S.M., Melo, A.L., Silva, M.J., Oliveira, L.S.D., Sales, M.F., 2015. Gradyana (Euphorbiaceae): a New Genus from Northeastern Brazil. Systematic Botany 40: 527-533.

Absy, M.L., 1979. A Palynological Study of Holocene Sediments in the Amazon Basin. Ph.D. thesis, University of Amsterdam, The Netherlands.

Absy, M.L., Cleef, A., Fournier, M., Martin, L., Servant, M., Sifeddine, A, Silva, M.F., Soubies, F., Suguio, K., Turcq, B., et al., 1991. Mise en évidence de quatre phases d'ouverture de la forêt dense dans le Sud-Est de l'Amazonie au cours des 60000 dernières années : première comparaison avec d'autres régions tropicales. Comptes Rendus de l'Académie des Sciences 312: 673678.

Agencia Nacional de Aguas (ANA), 2016. Hidroweb portal. Available at: http://www.snirh.gov.br/hidroweb. (Accessed 16 August 2016)

Apaéstegui, J., Cruz, F.W., Sifeddine, A., Vuille, M., Espinoza, J.C., Guyot, J.L., Khofri, M., Strikis, N., Santos, R.V., Cheng, H., et al., 2014. Hydroclimate variability of the northwestern Amazon Basin near the Andean foothills of Peru related to the South American Monsoon System during the last 1600 years. Climate of the Past 10: 1967-1981.

Behling, H., Hooghiemstra, H., 1998. Late Quaternary paleoecology and paleoclimatology from pollen records of the savannas of the Llanos Orientales in Colombia. Palaeogeography, Palaeoclimatology, Palaeoecology 139: 251-267.

Behling, H., Hooghiemstra, H., 1999. Environmental history of the Colombian savannas of the Llanos Orientales since the Last Glacial Maximum from lake records El Pinal and Carimagua. Journal of Paleolimnology 21: 461-476.

Behling, H., Berrio, J.C., Hooghiemstra, H., 1999. Late Quaternary pollen records from the middle Caquetá river basin in central Colombian Amazon. Palaeogeography, Palaeoclimatology, Palaeoecology 145: 193-213. 
Behling, H., Hooghiemstra, H., 2000. Holocene Amazon rainforest-savanna dynamics and climatic implications: High-resolution pollen record from Laguna Loma Linda in eastern Colombia. Journal of Quaternary Science 15: 687-695.

Behling, H., Keim, G., Irion, G., Junk, W., Mello, J.N., 2001. Holocene environmental changes in the central Amazon basin inferred from Lago Calado (Brazil). Palaeogeography, Palaeoclimatology, Palaeoecology 173: 87-101.

Bennett, K.D., 1996. Determination of the number of zones in biostratigraphical sequences. New Phytologist 132: 155-170.

Bennett, K.D., 2009. Psimpoll 4.27: C program for plotting pollen diagrams and analyzing pollen data. Queen's University of Belfast, Department of Archaeology and Palaeoecology. Available at: http://www.chrono.qub.ac.uk/psimpoll/psimpoll.html. (Accessed May 2016).

Berrio, J.C., Hooghiemstra, H., Behling, H., Botero, P., Van der Bog, K., 2002. LateQuaternary savanna history of the Colombian Llanos Orientales from Lagunas Chenevo and Mozambique: a transect synthesis. The Holocene 12: $35-48$.

Blaauw, M., 2010. Methods and code for 'classical' age-modelling of radiocarbon sequences. Quaternary Geochronology 5: 512-518.

Bush, M., Colinvaux, P.A., 1988. A 7000-Year Pollen Record from the Amazon Lowlands, Ecuador. Vegetatio 76: 141-154.

Bush, M.B., De Oliveira, P.E., Colinvaux, P.A., Miller, M.C., Moreno, J.E., 2004. Amazonian paleoecological histories: One hill, three watersheds. Palaeogeography, Palaeoclimatology, Palaeoecology 214: 359-393.

Bush, M.B., Silman, M.R., Toledo, M.B., Listopad, C., Gosling, W.D., Williams, C., De Oliveira, P.E., Krisel, C., 2007. Holocene fire and occupation in Amazonia: records from two lake districts. Philosophical Transactions of the Royal Society B 362: 209-218. 
Cheng, H., Sinha, A., Cruz, F.W., Wang, X., Edwards, R.L., d'Horta, F.M., Ribas, C.C., Vuille, M., Stott, L.D., Auler, A.S., 2013. Climate change patterns in Amazonia and biodiversity. Nature communications 4: 1411.

Clark, K., Uhl, C., 1987. Farming, fishing, and fire in the history of the upper Río Negro region of Venezuela. Human Ecology 15: 1-26.

Colinvaux, P.A., De Oliveira, P.E., Moreno, J.E., Miller, M.C., Bush, M.B., 1996. A long pollen record from lowland Amazonia: Forest and cooling in glacial times. Science 274: 85-88.

Colinvaux, P., De Olieira, P.E., Moreno, J.E., 1999. Amazon pollen manual and atlas. Harwood Academic publishers, The Netherlands.

Correa, A.M.S, Barros, M.A.V.C., Silvestre-Capelato, M.S.F., Pregun, M.A., Raso, P.G., Cordeiro, I., 2010. Flora polínica da Reserva do Parque Estadual das Fontes do Ipiranga (São Paulo, Brasil). Hoehnea 37:53-69.

Cordeiro, R.C., Turcq, B., Sifeddine, A., Lacerda, L.D., Silva Filho, E.V., Gueiros, B., Potty, Y.P., Santelli, R.E., Pádua, E.O., Patchinelam, S.R., 2011. Biogeochemical indicators of environmental changes from $50 \mathrm{Ka}$ to $10 \mathrm{Ka}$ in a humid region of the Brazilian Amazon. Palaeogeography, Palaeoclimatology, Palaeoecology 299: 426-436.

Cordeiro, R.C., Turcq, B., Moreira, L.S., Rodrigues, R.A.R., Simões Filho, F.F.L., Martins,G.S., Santos, A.B., Barbosa, M., Conceição, M.C.G., Rodrigues, R.C., 2014. Palaeofires in Amazon: Interplay between land use change and palaeoclimatic events. Palaeogeography, Palaeoclimatology, Palaeoecology 415: 137-151.

D'Apolito, C., Absy, M.L.,Latrubesse, E.M., 2013. The Hill of Six Lakes revisited: new data and re-evaluation of a key Pleistocene Amazon site. Quaternary Science Reviews 76: 140-155.

Esser, H.J., 2012 .The tribe Hippomaneae (Euphorbiaceae) in Brazil. Rodriguésia 63: 209-225.

Faegri, K., Iversen, J., 1989. Textbook of Pollen Analysis, fourth ed. Wiley, New York. 
Flantua, S.G.A., Hooghiemstra, H., Grimm, E.C., Behling, H., Bush, M.B., González-Arango,C., Gosling, W.D., Ledru, M.P., Lozano-García, S., Maldonado, A., et al., 2015. Updated site compilation of the Latin American Pollen Database. Review of Palaeobotany and Palynology 223: 104-115.

Flores, B.M., Piedade, M.T.F., Nelson, B.W., 2014. Fire disturbance in Amazonian blackwater floodplain forests. Plant Eology and Diversity 7: 319-327.

Flores, B.M., Fagoaga, R., Nelson, B.W., Holmgren, M., 2016. Repeated fires trap Amazonian blackwater floodplains in an open vegetation state. Journal of Applied Ecology 53: 1597-1603.

Goulding, M.R., Barthem, R., Ferreira, E., 2003. The Smithsonian Atlas of the Amazon. Smithsonian Institute. Princeton Editorial Associates.

Grimm, E.C., 1987. CONISS: a fortran 77 program for stratigraphically constrained cluster analysis by the method of the incremental sum of squares. Computers and Geosciences 13: 13-35.

Grimm, E.C., 2015. Tilia/TGView 2.0.41. Illinois State Museum, Research and Collections Center.

Hermanowski, B., Costa, M.L., Behling, H., 2012a. Environmental changes in southeastern Amazonia during the last $25,000 \mathrm{yr}$ revealed from a paleoecological record. Quaternary Research 77: 138-148.

Hermanowski, B., Costa, M.L., Carvalho, A.T., Behling, H., 2012b. Palaeoenvironmental dynamics and underlying climatic changes in southeast Amazonia (Serra Sul dos Carajás, Brazil) during the late Pleistocene and Holocene. Palaeogeography, Palaeoclimatology, Palaeoecology 365-366: 227-246.

Hermanowski, B., Costa, M.L., Behling, H., 2014. Possible linkages of palaeofires in southeast Amazonia to a changing climate since the Last Glacial Maximum. Vegetation History and Archaeobotany 24: 279-292.

Hill, M.O., 1973. Diversity and evenness: a unifying notation and its consequences. Ecology 54: 427-473. 
Instituto Nacional de Metereologia (INMET), 2016. Ministério da Agricultura, Pecuária e Abastecimento. Available at: http://www.inmet.gov.br. (Accessed 10 July 2016).

Instituto Nacional de Pesquisas Espaciais (INPE), 2016. Ministério da Ciencia, Tecnologia e Inovaçao. Available at: http://www.inpe.br. (Accessed 5 August 2016).

Irion, G., Bush ,M.B., Mello, J.A.N., Stüben, D., Neumann, T., Müller, G., Morais, J.O., Junk, J.W., 2006. A multiproxy palaeoecological record of Holocene lake sediments from the Rio Tapajós, eastern Amazonia. Palaeogeography, Palaeoclimatology, Palaeoecology 240: 523-535.

Jiménez-B, L.C., Bogotá, R.G., Rangel-Ch, O., 2008. Atlas palinológico de la Amazonia Colombiana- Las familias más ricas en especies. In: Rangel-Ch O (ed). Colombia diversidad biótica VII: vegetación, palinología y paleoecología de la amazonía Colombiana. National University of Colombia, Natural Sciences Institute, pp.217-412.

Junk, W.J., Piedade, M.T.F., Schöngart, J., Cohn-Haft, M., Adeney, J.M., Wittmann, F., 2011. A classification of major naturally-occurring amazonian lowland wetlands. Wetlands 31: 623-640.

Junk, W.J., Piedade, M.T.F., Wittmann, F., Schöngart, J., Parolin, P., 2010. Amazonian Floodplain Forests: ecophysiology, biodiversity and sustainable management. Springer.

Latrubesse, E.M., Franzinelli, E., 1998. Late Quaternary Alluvial Sedimentation in the Upper Rio Negro Basin, Amazonia, Brazil: Palaeohydrological Implications. In: Benito, G., Baker ,V.R., Gregory, K.J., (eds): Palaeohydrology and Environmental Change. John Wiley \& Sons Ltd, pp. 259-271.

Latrubesse, E.M., Franzinelli, E., 2005. The late Quaternary evolution of the Negro River, Amazon, Brazil: Implications for island and floodplain formation in large anabranching tropical systems. Geomorphology 70: 372-397. 
Ledru, M.P., 2001. Late holocene rainforest disturbance in French Guiana. Review of Palaeobotany and Palynology 115: 161-176.

Levine, N.M., Zhang, K., Longo, M., Baccini, A., Phillips, O.L., Lewis, S.L., AlvarezDavila, E., Andrade, A.C.S., Brienen, R.J.W., et al., 2016. Ecosystem heterogeneity determines the ecological resilience of the Amazon to climate change. Proceedings of the National Academy of Sciences 113: 793-797.

Martinelli, L.A., Victoria, R.L., Camargo, P.B., Piccolo, M.C., Mertes, L., Richey, J.E., Devol, A.H., Forsberg, B.R., 2003. Inland variability of carbon-nitrogen concentrations and $\partial^{13} \mathrm{C}$ in Amazon floodplain (várzea) vegetation and sediment. Hydrological Processes 17: 1419-1430.

Matthias, I., Semmler, M.S.S., Giesecke, T., 2015. Pollen diversity captures landscape structure and diversity. Journal of Ecology 103: 880-890.

Meneses, M.E.N.S., Costa, M.L., Behling, H., 2013. Late Holocene vegetation and fire dynamics from a savanna-forest ecotone in Roraima state, northern Brazilian Amazon. Journal of South American Earth Sciences 42: 17-26.

Mesquita, R.C.G., Massoca, P.E.S., Jakovac, C.C., Bentos, T.V., Williamson, G.B., 2015. Amazon Rain Forest Succession: Stochasticity or Land-Use Legacy? BioScience 65: 849-861.

Meyers, P.A., 2003. Applications of organic geochemistry to paleolimnological reconstructions : a summary of examples from the Laurentian Great Lakes. Organic Geochemistry 34: 261-289.

Montero, J.C., 2012. Floristic Variation of the Igapó Forests along the Negro River, Central Amazonia. PhD Thesis, University of Freiburg, Germany

Montero, J.C., Piedade, M.T.F., Wittmann, F., 2012. Floristic variation across 600 $\mathrm{km}$ of inundation forests (Igapó) along the Negro River, Central Amazonia. Hydrobiologia 729: 1-18.

Montero, J.C., Latrubesse, E.M., 2013. The igapó of the Negro River in central Amazonia: Linking late-successional inundation forest with fluvial geomorphology. Journal of South American Earth Sciences 46: 137-149. 
Moran, E.F., 1995. Rich and Poor Ecosystems of Amazonia: An Approach to Management The fragile tropics of Latin America. In:Nishizawa $T$ and Uitto JI (eds). The fragile tropics of Latin America:Sustainable management of changing environments. Tokyo: United Nations University, pp. 45-67.

Oksanen, J., Blanchet, F.G., Kindt, R., Legendre, P., Minchin, P.R., O'Hara, R.B., Simpson, G.L., Solymos, P., Stevens, M.H.H., Wagner, H., 2015. Vegan: Community Ecology Package. $\mathrm{R}$ package version 2.3-0. Available at: http://CRAN.R-project.org/package=vegan.

Oliveira, M.D.S.P., Couturier, G., Beserra, P., 2003. Biologia da polinização da palmeira tucumã (Astrocaryum vulgare Mart.) em Belém, Pará, Brasil. Acta Botanica Brasilica 17: 343-353.

Piedade, M.T.F., Parolin, P., Junk, W.J., 2006. Phenology, fruit production and seed dispersal of Astrocaryum jauari (Arecaceae) in Amazonian black water floodplains. Revista de Biologia Tropical 54: 1171-1178.

R Development Core Team, 2016. R: a Language and Environment for Statistical Computing. R Foundation for Statistical Computing, Vienna, Austria, ISBN 3-900051-07-0. Available at: http://www.R-project.org.

Rangel-Ch, O., Bogotá, R.G., Jiménez-B, L.C., 2001. Atlas palinológico de la Amazonia Colombiana. IV. Familia Arecaceae. Caldasia 23: 281-300.

Ramos, S.L.F., Dequigiovanni, G., Sebbenn, A.M., Lopes, M.T.G., Kageyama, P.Y., Macêdo, J.L.V., Kirst, M., Veasey, A., 2016. Spatial genetic structure, genetic diversity and pollen dispersal in a harvested population of Astrocaryum aculeatum in the Brazilian Amazon. BMC Genetics 17:63.

REFLORA, 2016. List of species of the Brazilian Flora. Rio de Janeiro Botanical Garden. Available at: http://floradobrasil.jbrj.gov.br/. Last access on: November 2016.

Reimer, P.J., Bard, E., Bayliss, A., Beck, J.W., Blackwell, P.G., Ramsey, C.B., Buck, C.E., Edwards, R.L., Friedrich, M., et al., 2013. IntCal13 and Marine13 radiocarbon age calibration curves, 0-50,000 years cal BP. Radiocarbon 55: 1869-1887. 
Ritter, C.D., Andretti, C.B., Nelson, B.W., 2012. Impact of Past Forest Fires on Bird Populations in Flooded Forests of the Cuini River in the Lowland Amazon. Biotropica 44: 449-453.

Rodríguez-Zorro, P.A., Enters, D., Hermanowski, B., Costa, M.L., Behling, H., 2015. Vegetation changes and human impact inferred from an oxbow lake in southwestern Amazonia, Brazil since the 19th century. Journal of South American Earth Sciences 62: 186-194.

Rull, V., Montoya, E., Nogué, S., Vegas-Vilarrúbia, T., Safont, E., 2013. Ecological palaeoecology in the neotropical Gran Sabana region: Long-term records of vegetation dynamics as a basis for ecological hypothesis testing. Perspectives in Plant Ecology, Evolution and Systematics 15: 338-359.

Rull, V., Montoya, E., Vegas-Vilarrúbia, T., Ballesteros, T., 2015. New insights on palaeofires and savannisation in northern South America. Quaternary Science Reviews 122: 158-165.

Saldarriaga, J.G., West, D.C., 1986. Holocene fires in the northern Amazon basin. Quaternary Research 26: 358-366.

Sales, E.O., Barreto, C.F., Barth, M.O., 2011. Morfologia polínica de espécies de Euphorbiaceae s.l. arbóreas ocorrentes no Estado de Santa Catarina, Brasil. Hoehnea 38: 495-500.

Santos, G.M., Cordeiro, R.C., Silva-Filho, E.V., Turcq,B., Lacerda, L.D., Fifield, L.K., Gomes, P.R.S., Hausladen, P.A., Sifeddine, A., Albuquerque,A.L., 2001. Chronology of the atmospheric Mercury in lagoa da pata basin, upper Rio Negro of Brazilian Amazon. Radiocarbon 43: 801-808.

Sifeddine, A., Martin, L., Turcq, B., Volkmer-Ribeiro, C., Soubiès, F., Cordeiro, R.C., Suguio, K., 2001. Variations of the Amazonian rainforest environment: A sedimentological record covering 30,000 years. Palaeogeography, Palaeoclimatology, Palaeoecology 168: 221-235.

Simões Filho, F.L., Turcq, B.J., Sifeddine, A., 2010. Mudanças paleoambientais do contato floresta-savana de Roraima durante o Holoceno. In: Barbosa, R.I., 
Ferreira-Melo, V., (Eds) Roraima: Homem, Ambiente e Ecologia. Boa Vista, FEMACT. pp. 257-282.

Stockmarr, J., 1971. Tablets with spores used in absolute pollen analysis. Pollen et Spores 13, 615- 621.

Ter Steege, H., Pitman, N.C.A., Sabatier, D., Baraloto, C., Salomão, R.P., Guevara, J.E., Phillips, O.L., Castilho, C.V., Magnusson, W.E., Molino, J.F., et al., 2013. Hyperdominance in the Amazonian tree flora. Science 342: 1243092.

Van der Hammen, T., Hooghiemstra, H., 2000. Neogene and Quaternary history of vegetation, climate, and plant diversity in Amazonia. Quaternary Science Reviews 19: 725-742

Vuille, M., Burns, S.J., Taylor, B.L., Cruz, F.W., Bird, B.W., Abbott, M.B., Kanner, L.C., Cheng, H., Novello, V.F., 2012. A review of the South American monsoon history as recorded in stable isotopic proxies over the past two millennia. Climate of the Past 8: 1309-1321. 


\section{CHAPTER 5}

\section{Synthesis}

How much can you get out of the unsatisfactory material available?

Birks and Birks, 1980

This chapter synthesizes and discusses the main outcomes of a palaeoecological reconstruction in the western part of Amazonia in Brazil. The records used for this research reflect the responses of vegetation and lake dynamics at different time scales and geomorphological locations. This research contributes to the understanding of the past fluvial dynamics in the Brazilian Amazon lowlands (Chapters 2 to 4). According to the main findings of the research, this section is

divided into the origin of the sediment deposits, floodplain lakes and savanna, the climatic drivers and the observed human disturbances among the records. 


\section{The floodplain lake records}

The Amazon basin contains the most extensive floodplain system in the world, where the majority of the lakes were generated by fluvial processes and thereforeshow in a wide diversity depending on their origin, shape, and functioning (Latrubesse, 2012). The two floodplain records, Lago Amapá and Lake Acarabixi (Chapter 2 and 4), have shown the role of the floodplain dynamics regarding past input of sediments and water flux into the lakes. The lakes were partially or completely connected to the main river channel in some phases of their history, which therefore affected the morphodynamics and hydro-biogeochemical input in both lakes (Latrubesse, 2012).

The sediments from Lago Amapá showed that the lake is of recent origin (ca. 100 years old). In the earliest phase of the lake, around $1900 \mathrm{AD}$, the oxbow lake has been mostly influenced by the Acre River's main channel (Figures 3 and 4, Chapter 2). The high input of terrigenous material from eroded sediments during raised stands of the Acre River was detected by thicker light laminations and high peaks in the Ti curve (Haug et al., 2001; Enters et al., 2010a). At that time, the lake was oxygenated since there was more water flux. Such fluvial dynamics also played a role on vegetation assemblages in the surroundings of the lake. Pollen diversity was higher and a higher representation of taxa of swamp and floodplain forests was observed. Additionally, the occurrence of the pioneer Cecropia tree indicated, that the main changes in vegetation during this period were caused by the seasonality of the river rather than human impact, considering the fluvial dynamic as the main factor of transformation (Kalliola et al., 1991; Morais et al., 2008).

The second period of changes in the Lago Amapá record suggested that there was a reduction on the effect of the floodplain dynamics with an increase on anthropogenic disturbances in the surroundings of the lake. From ca. 1950 AD the lake was only connected to the main Acre river channel in sporadic high flood events. At that time, new sediment sources were detected from the XRF analyses and attributed to human disturbances. The $\mathrm{Ti} / \mathrm{K}$ ratio as a parameter for grain-size indicated that coarser grained terrigenous material became deposited in the lake probably from a short distance (the uppermost $50 \mathrm{~cm}$ ) (Dean, 1993; Enters et al., 2010b). Additionally, the further increase of Cecropia and the appearance of other pioneer taxa (Trema, Asteraceae, Poaceae) can be interpreted as sign of strongly 
disturbed forests where clearance for cattle breeding and logging was practiced adjacent to the lake (see Bush and Colinvaux, 1988; Weng et al., 2002; Irion et al., 2006).

Contrary to the palaeoenvironmental changes found in the Lago Amapá record, the Lake Acarabixi sediment record reflected the dynamics of a River with a different geological and geomorphologic origin (Figures 2 to 4 , Chapter 1).

The past dynamics of Lake Acarabixi can be divided into two main periods as a result of the Rio Negro valley filling (Latrubesse and Franzinelli, 2005). The first phase occurred from 10,840 to $8240 \mathrm{cal} \mathrm{BP}$, when the lake was subject to a direct influence from the water flux coming from a channel of the Rio Negro. The stratigraphy and geochemical data revealed that at such time the lake was getting filled with coarse sand sediments until 10,660 cal BP. After that, a lateral channel migration occurred, resulting in the lake becoming richer in silt and organic matter. Towards $8240 \mathrm{cal}$ BP the deposition of sediments stopped, probably as a result of the migration of the river channel, and consequently, a large hiatus in sediments occurred during the mid-Holocene. The vegetation dynamics for the early Holocene showed that taxa of lowland forest were dominant. The forest had a more open canopy and more herbs grew there than in recent times. In this context, the presence of more open areas could have been the result of frequent low water levels in the area, and therefore some grasses and herbs might have grown in the exposed sandy banks.

The second recroded phase of past dynamics in Lake Acarabixi occurred from 1600 to $650 \mathrm{cal}$ BP. The lake was permanently flooded and there was a reduced influence from the main Rio Negro channel, although it was subject to intense discharge events that supply the lake with coarse to medium sands from the small present-day tributaries. During this period, drastic changes in vegetation did not occur, but forest species developed, that were more tolerant to longer periods of flooding. In fact, the forest was resilient to the floodplain and climate dynamics since the early Holocene.

In general, both lake records displayed highly dynamic environments in which vegetation evolved differently in time and space. In the case of Lago Amapá, the changes in vegetation were more influenced by human disturbances than by the 
floodplain dynamics. The extreme rate of forest clearance as a result of the Rio Branco city expansion, drastically changed the vegetation composition and lake dynamics since ca. 1950 up until today. On the other hand, Lake Acarabixi reflects that forest vegetation was resilient to floodplain dynamics and climate. The presence of humans in the area at that time is unconfirmed, as there are no reported archaeological evidences or other palaeoecological studies reflecting that humans have been there in the past. However, if humans had been in the area, their impact on vegetation was not as extreme as those found in Lago Amapá (see human impact discussion below). In Lake Acarabixi, the floodplain dynamics played a role on the vegetation composition, where forests and palm trees adapted to the high sedimentation rates and water fluxes, low nutrients content and climatic events, consequently reflecting that they have been resilient at least since the early Holocene.

\section{The savanna record}

The Serra do Tepequém sediment record is located in a singular geological formation in the Amazon region, which is composed by several transition zones where Mauritia flexuosa palm sporadically grows. The transitions zones such as forest-savanna mosaics are very sensitive to environmental changes and hence helpful to understand past vegetation dynamics. Likewise, the presence of $M$. flexuosa can be used as an indicator of wet environments, since it develops on diverse habitats with common geological and soil characteristics such as anoxic clay or sandy soils, poorly drained and frequent flooded areas, abundant organic material and high water tables (Lasso et al., 2013; Rull and Montoya, 2014; Galeano et al., 2015).

The palaeoecological reconstruction of Serra do Tepequém showed that during the mid-Holocene the latitudinal migration of the ITCZ, as main driver of seasonality in the area, played an important role on the vegetation assemblages (Chapter 3). Such an effect on precipitation was also detected in other palaeoecological records from the savannas of northern South America, which allowed a regional comparison (Roraima savannas in Brazil, the Gran Sabana in Venezuela and the Llanos Orientales in Colombia) (Hooghiemstra and Berrio, 2007; Simões Filho et al., 2010; Rull et al., 2013). 
The stratigraphy and past vegetation assemblages showed a drastic change from an area that was mainly dominated by grassland savanna towards an area with frequent flooded areas, which favored the development of forest and the palm stands of Mauritia flexuosa (Chapter 3). The earliest phase of the record (7570 to $6190 \mathrm{cal} \mathrm{BP}$ ) was characterized by a landscape dominated by grassland savannas with some forest patches, and a prevalent signal of regional fires. During this period, a southernmost position of the ITCZ produced longer dry periods that favored the development of savanna and open vegetation. Towards $6600 \mathrm{cal} \mathrm{BP}$, a regional increase of wetter conditions was found among the compared savanna records, which in Serra do Tepequém is clearly reflected by the earliest expansion of the M.flexuosa palm. After that, a wetter environment dominated from 6190 to $4900 \mathrm{cal} \mathrm{BP}$, with an increase of organic deposits and the reduction of regional fire signal in the record.

\section{Climatic Drivers}

The most sensitive record on climatic changes during the Holocene was Serra do Tepequém (Chapter 3). In fact, the latitudinal migration of the ITCZ was in charge of the amount of precipitation that the plateau received in the past, hence affecting the vegetation assemblages in the area. This assumption is also supported by climatic reconstructions including several palaeoecological records from the surrounding regions (e.g Haug et al., 2001; Rull et al., 2013; Cheng et al., 2013).

On the other hand, the climatic changes that could have happened in the Lake Acarabixi record can be related to the ITCZ latitudinal effect together with the flux of moisture coming from the SAMS (Vuille et al., 2012; Cheng et al., 2013). The reconstruction of vegetation of Lake Acarabixi does not give a clear indication whether dry or wet climates occurred. However, recent climatic models in the Amazon allowed reconstructing the possible climatic scenario in the area (Cheng et al., 2013, Wang et al., 2017). The climatic reconstruction reported dry periods for the early Holocene in the area where Lake Acarabixi is located, as the ITCZ had a longer incursion toward the South at that time and there was a weak signal from the SAMS. Obviously, the Lake Acarabixi was more susceptible to the changes from the river dynamics during the early Holocene, but such dynamics were also affected by the amount of precipitation, which in longer dry periods allowed herbs to grow in exposed sandy banks (Chapter 4). In addition to that, the Lake 
Acarabixi sediments have a huge hiatus in sedimentation that hampered the reconstruction of the mid-Holocene in the record. However, if we compare the changes in vegetation and the sediment composition of the Serra do Tepequém record at that time, we could expect that the intensity of rains and the filling of the valley of the Rio Negro were also affected by a more seasonal period with an increase on precipitation. In the late Holocene, several palaeoecological and palaeoclimatic records show a trend of wetter climates. In the Lake Acarabixi, the effect of a more northerly position of the ITCZ could be reflected by the presence of taxa that are tolerant to long periods of flood (Apaéstegui et al., 2014).

Regarding the Lago Amapá record, the climatic drivers cannot be detected with the data obtained so far. Although the lake lacks of a strong chronology, we could interpret that the banding that we observed in the sediments could be related to the annual seasonality. Such hypothesis, however, should be tested, using a different dating method or better analyzing new sediment cores in the area.

\section{Human impact}

The clearest signal of human disturbances among the analyzed records was found at the Lago Amapá sediment record. The palaeoecological reconstruction of Lago Amapá showed a highly transformed landscape as a result of Rio Branco City expansion. The vegetation dynamics were mostly driven by the effect of the logging in the surroundings rather than only by the dynamics of the Acre River (Chapter 2). Although with this record we are not certainly sure when the humans started to transform the landscape, there are several archaeological sites that reported that humans were in the Acre state since $4000 \mathrm{cal}$ BP (Saunaluoma and Schaan, 2012).

On the other hand, the Serra do Tepequém record may show what could also be a highly impacted landscape (Chapter 3). Firstly, the high amount of charred particles in the sediments, together with Gelasinospora fungal spore (indicator of local fire occurrence), could indicate possible human disturbances in the area. Moreover, the changes in forest and fern composition for the wettest period of the record possibly indicate an abandonment of the land. Consequently, this study shows that the area has a potential for archaeological research, which will bring a clearer view of the role of ancient cultures in relation to vegetation changes and fire. 
At last, the Lake Acarabixi record could be indicating human disturbances for the late Holocene. Although fires are common in such areas during extremely dry years (Flores et al., 2014), we could hypothesize that the area was subject to human disturbances since $1400 \mathrm{cal} \mathrm{BP}$, as there was an increase in charred particles and pioneer species affected by periodical burns at that time (Chapter 3). However, these assumptions should remain open until more palaeoecological and archaeological studies have been developed in the area.

\section{Conclusions}

The results of this palaeoecological research revealed different responses of vegetation to temporal and spacial factors in the western Brazilian Amazon.

The records from the floodplains showed to be more susceptible to the floodplain dynamics and human impact than to the influence of climate. The Lago Amapá record gives important insights into the fluvial dynamics of meandering rivers in the Acre state of Brazil. The record mainly showed a local signal of forest disturbances as a result of human impact in the surroundings of the lake. Consequently, the results of this research strongly encourage the scientific community to develop conservation strategies to preserve the fauna and flora in the surroundings of Rio Branco City.

The Lake Acarabixi record reveals the development of a floodplain lake during the Holocene, which indicates that lowland forest was resilient to the dynamics of the Rio Negro. The results of this research showed that the filling of Rio Negro valley played an important role in the developing of the lacustrine phase of Lake Acarabixi, but such an effect was not drastically affecting forest development. The main finding of this studied area was that forests were resilient to the fluvial dynamics of the Rio Negro and the climate during the Holocene.

At last, the record of savanna mosaics, Serra do Tepequém, supported a regional increase in wetter conditions for the mid-Holocene with an early expansion of Mauritia flexuosa palm. This study showed that the area has a potential for archaeological research, which would bring clear view of the role of ancient cultures in relation to vegetation changes and fire. 


\section{Remained open questions and outlook}

The palaeoecological reconstruction of these three records contributes to the knowledge of different past fluvial dynamics in the western Brazilian Amazon, but also leaves many open questions about the future research on the subject.

Firstly, the different dynamics and the origin of the floodplain lakes should be considered to develop palaeoecological investigations. For future palaeoecological research in the Acre River floodplains, for instance, it would be of interest to try and infer a different methodology for dating the sediment records as probably most of the oxbow lakes in such floodplains are of young ages. In addition to that, the Acre River flood plains are very interesting places to work on palaeoecology, as the effect of pre-Columbian cultures on the vegetation still remains unclear. Human settlement in the area could be tested using several analyses combining archaeology, geology and palaeoecology. Moreover, apart from increasing the palaeoecological knowledge in this region, it is primordial to develop conservation strategies that protect the ecosystems in those lowlands.

Regarding the floodplains of the Rio Negro, research should focus on several aspects to comprehend the vegetation, the river, and climate dynamics. The middle-upper part of the Rio Negro lacks studies in areas such as ecology, archaeology, limnology, which could contribute to improve the work for future palaeoecological research. The results of Lake Acarabixi lack a mid-Holocene environmental reconstruction, which could confirm that forests were also resilient at that time.

The main open question regarding Serra do Tepequém is the impact of ancient cultures in the area. Future research on macrocharcoal, phytoliths and more palaeoenvironmental reconstructions could bring a better assessment of human settlement on the plateau. On the other hand, the obtained age depth model of the record, using Bayesian statistics, showed the robustness of the outlier detection incorporated in Bacon (Blaaw and Christen, 2011), which encourages the scientific community to incorporate it to their palaeoecological research (see Chapter 3).

In general, all the records lack of modern pollen - vegetation relationship analyses, which could improve and strengthen our interpretations. Future investigations on this topic could assist to develop research with a more quantitative focus, as 
pollen-vegetation relationships are the base for a comprehensive calibration of palaeoecological records.

\section{References}

Apaéstegui, J., Cruz, F.W., Sifeddine, A., et al., 2014. Hydroclimate variability of the northwestern Amazon Basin near the Andean foothills of Peru related to the South American Monsoon System during the last 1600 years. Climate of the Past 10: 1967-1981.

Blaauw, M., Christen, J.A., 2011. Flexible paleoclimate age-depth models using an autoregressive gamma process. Bayesian Anal 6:457-474.

Bush, M.B., Colinvaux, P.A., 1988. A 7000-year pollen record from the Amazon lowlands, Ecuador. Vegetation 76, 141-154.

Birks, H.J.B., Birks, H.H., 1980. Quaternary Palaeoecology. Edward Arnold, London.

Cheng, H., Sinha, A., Cruz, F.W., et al., 2013. Climate change patterns in Amazonia and biodiversity. Nature Communication 4:1,411

Dean, W.E., 1993. Physical properties, mineralogy, and geochemistry of Holocene varved sediments from Elk Lake, Minnesota, in Bradbury, J.P, and Dean, W.E., (eds), Elk Lake, Minnesota: Evidence for Rapid Climate Change in the North-Central United States: Boulder, Colorado, Geological Society of America 276: 135-157.

Enters, D., Behling, H., Mayr, C., et al., 2010a. Holocene environmental dynamics of south-eastern Brazil recorded in laminated sediments of Lago Aleixo. Journal of Paleolimnology 44: 265-277.

Enters, D., Kirilova, E., Lotter, A. F., et al., 2010b. Climate change and human impact at Sacrower See (NE Germany) during the past 13,000 years: A geochemical record. Journal of Paleolimnology 43: 719-737.

Flores, B.M., Piedade, M.T.F., Nelson, B.W., 2014. Fire disturbance in Amazonian blackwater floodplain forests. Plant Eology and Diversity 7: 319-327. 
Galeano, A., Urrego, L.E., Sánchez, M., et al., 2015. Environmental drivers for regeneration of Mauritia flexuosa L.f. in Colombian Amazonian swamp forest. Aquatic Botany 123:47-53.

Haug, H.G., Hughen, K.A., Sigman, D.M., et al., 2001. Southward Migration of the Intertropical Convergence Zone Through the Holocene. Science 293, 13041307.

Hooghiemstra, H., Berrio, J.C., 2007. South America: Pollen record from the Colombian savannas. In: Elias S (ed) Encyclopedia of Quaternary Science. Elsevier, Amsterdam, pp. 2654-2659

Irion, G., Bush, M.B., Mello, J.A.N., et al., 2006. A multiproxy palaeoecological record of Holocene lake sediments from the Rio Tapajós, eastern Amazonia. Palaeogeography, Palaeoclimatology, Palaeoecology 240: 523-535.

Kalliola, R., Salo, J., Puhakka, M., et al., 1991. New site formation and colonizing vegetation in primary succession on the western amazon floodplains. Journal of Ecology 79: 877-901.

Lasso, C.A., Rial, A., González-B,V., (eds) 2013. Morichalesy canangunchales de la Orinoquia y Amazonia: Colombia - Venezuela. Parte I. Serie Editorial Recursos Hidrobiológicos y Pesqueros Continentales de Colombia. Instituto de Investigación de Recursos Biológicos Alexander von Humboldt (IAvH). Bogotá, D. C., Colombia

Latrubesse, E.M., Franzinelli, E., 2005. The late Quaternary evolution of the Negro River, Amazon, Brazil: Implications for island and floodplain formation in large anabranching tropical systems. Geomorphology 70: 372-397.

Latrubesse, E., 2012. Amazon Lakes. In: . Bengtsson, L., Herschy,R., and Fairbridge, R. (Eds) Lakes and Reservoirs. Springer Verlag, 13-26.

Morais, R.P., Aquino, S., Latrubesse, E.M., 2008.Controles hidrogeomorfológicos nas unidades vegetacionais da planície aluvial do rio Araguaia, Brasil. Acta Scientiarum Biological Sciences 30: 411-421.

Rull, V., Montoya, E., Nogué, S., et al., 2013. Ecological palaeoecology in the neotropical Gran Sabana region: Long-term records of vegetation dynamics 
as a basis for ecological hypothesis testing. Perspectives in Plant Ecology, Evolution and Systematics 15:338-359

Rull, V., Montoya, E., 2014. Mauritia flexuosa palm swamp communities: Natural or human-made? A palynological study of the Gran Sabana region (northern South America) within a neotropical context. Quaternaary Science reviews 99:17-33.

Saunaluoma, S., Schaan, D., 2012. Monumentality in western Amazonian formative societies: geometric ditched enclosures in the Brazilian state of Acre. Antiqua 2: 1-11.

Simões Filho, F.L., Turcq, B.J., Sifeddine, A., 2010. Mudanças paleoambientais do contato floresta-savana de Roraima durante o Holoceno. In: Barbosa RI, Ferreira-Melo V (eds) Roraima: Homem, Ambiente e Ecologia. FEMACT, Boa Vista, pp 257-282.

Vuille, M., Burns, S.J., Taylor, B.L., et al., 2012. A review of the South American monsoon history as recorded in stable isotopic proxies over the past two millennia. Climate of the Past 8: 1309-1321.

Wang, X., Edwards, L.R., Auler, A.S., et al., 2017. Hydroclimate changes across the Amazon lowlands over the past 45,000 years Nature Letter 541: 204-207.

Weng, C., Bush, M.B., Athens, J.S., 2002. Holocene climate change and hydrarch succession in lowland Amazonian Ecuador. Review of Palaeobotany and Palynology

120 ,

73-90. 
Chapter 5 - Synthesis- 


\section{APPENDIX}




\section{APPENDIX 1}

Pollen list and pictures of some of the identified pollen taxa 


\begin{tabular}{|c|c|c|c|}
\hline Family & Pollen type & Photo & Record \\
\hline Amaranthaceae/Chenopodiaceae & Amaranthaceae/Chenopodiaceae & 1 to 3 & LA,ACA, \\
\hline Anacardiaceae & Spondias & 4,5 & LA \\
\hline Annonaceae & Annonaceae & 6 & LA,ACA,TEP \\
\hline Apocynaceae & Malouetia & 7,8 & ACA \\
\hline Apocynaceae & Macoubea guianensis & 9 & TEP, ACA \\
\hline Apocynaceae & Parahancornia & 10 to 12 & ACA \\
\hline Aquifoliaceae & Ilex & 13,14 & ACA, TEP,LA \\
\hline Arecaceae & Astrocaryum & 15,16 & ACA, TEP \\
\hline Arecaceae & Bactris & 17,18 & LA,TEP,ACA \\
\hline Arecaceae & Iriartea & 19,20 & ACA,LA \\
\hline Arecaceae & Mauritia & 21,22 & ACA,TEP,LA \\
\hline Bombacaceae & Bombacaceae & 23,24 & LA \\
\hline Bombacoideae & Bombacoideae & 25,26 & ACA \\
\hline Burseraceae & Protium & 27,28 & TEP, ACA \\
\hline Caryocaraeceae & Caryocar & 29,30 & ACA \\
\hline Chloranthaceae & Hedyosmum & 31,32 & ACA,LA \\
\hline Clusiaceae & Clusia cochclitheca & 33,34 & TEP \\
\hline Combretaceae Type & Combretaceae Type & 35,36 & ACA \\
\hline Convolvulaceae & Dicranostyles & 37,38 & ACA \\
\hline Convolvulaceae & Maripa & 39,40 & ACA \\
\hline Cyperaceae & Cyperaceae & 41 & ACA,TEP,LA \\
\hline Euphorbiaceae & Alchornea & 42 to 45 & TEP, ACA \\
\hline Euphorbiaceae & Mabea & 46,47 & ACA,TEP \\
\hline Fabaceae & Copaifera guyanensis & 48,49 & ACA \\
\hline Fabaceae & Crudia amazonica & 50,51 & $\mathrm{ACA}$ \\
\hline Fabaceae & Macrolobium & 52,53 & ACA \\
\hline Fabaceae & Mimosaceae - polyade & 54,55 & LA,TEP,ACA \\
\hline Fabaceae & Senna & 56,57 & ACA \\
\hline Fabaceae & Swartzia & 58 to60 & ACA \\
\hline Hypericaceae & Hypericum type & $61-63$ & TEP \\
\hline Hypericaceae & Vismia & 64 to 67 & ACA \\
\hline Malpighiaceae & Malpighiaceae & 68,69 & ACA,TEP,LA \\
\hline Malvaceae & Catostemma & 70,71 & ACA \\
\hline Malvaceae & Heliocarpus americanus & 72,73 & LA \\
\hline Malvaceae & Lueheopsis & 74 to 76 & ACA \\
\hline
\end{tabular}




\begin{tabular}{|l|l|c|l|}
\hline Meliaceae & Guarea & 77,78 & ACA \\
\hline Meliaceae & Meliaceae & 79,80 & ACA \\
\hline Moraceae & Ficus & 81 & ACA,LA \\
\hline Myrtaceae & Myrtaceae & 82 & ACA,LA, TEP \\
\hline Poaceae & Poaceae & 83,84 & ACA,TEP,LA \\
\hline Polygalaceae & Polygalaceae & 85 to 87 & ACA,TEP \\
\hline Phytolaccaceae & Phytolacca type & 88,89 & ACA,TEP \\
\hline Primulaceae & Myrsine & 90,91 & ACA,LA \\
\hline Rhamnaceae & Rhamnaceae & 92,93 & ACA \\
\hline Rubiaceae & Alibertia edulis & 94 to 97 & ACA \\
\hline Rubiaceae & Amanoa & 98,99 & ACA \\
\hline Rubiaceae & Ferdinandusa & 100,101 & ACA \\
\hline Rubiaceae & Spermacoce & 102,103 & ACA \\
\hline Salicaceae & Casearia type 2 & 104,105 & ACA \\
\hline Salicaceae & Casearia type 3 & 106,107 & ACA \\
\hline Salicaceae & Casearia type 4 & 108,109 & ACA \\
\hline Ulmaceae & Celtis & 110 to & LA,TEP,ACA \\
\hline Ulmaceae & & 112,114 & LA,TEP,ACA \\
\hline Urticaceae & Trema & 115,116 & LA,TEP,ACA \\
\hline
\end{tabular}

*LA: Lago Amapá; TEP: Serra do Tepequém; ACA: Lake Acarabixi. 


\section{Pollen Atlas}
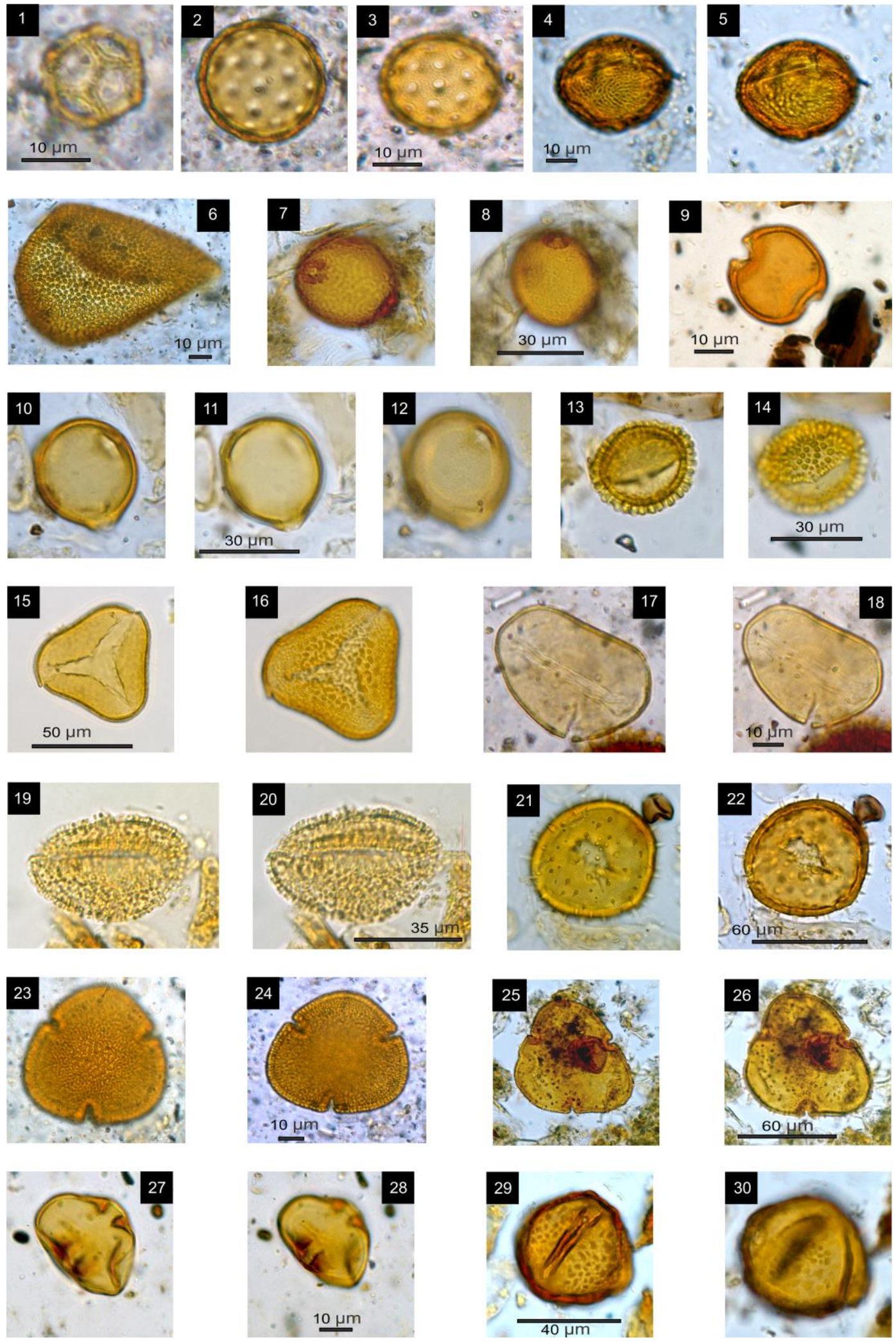

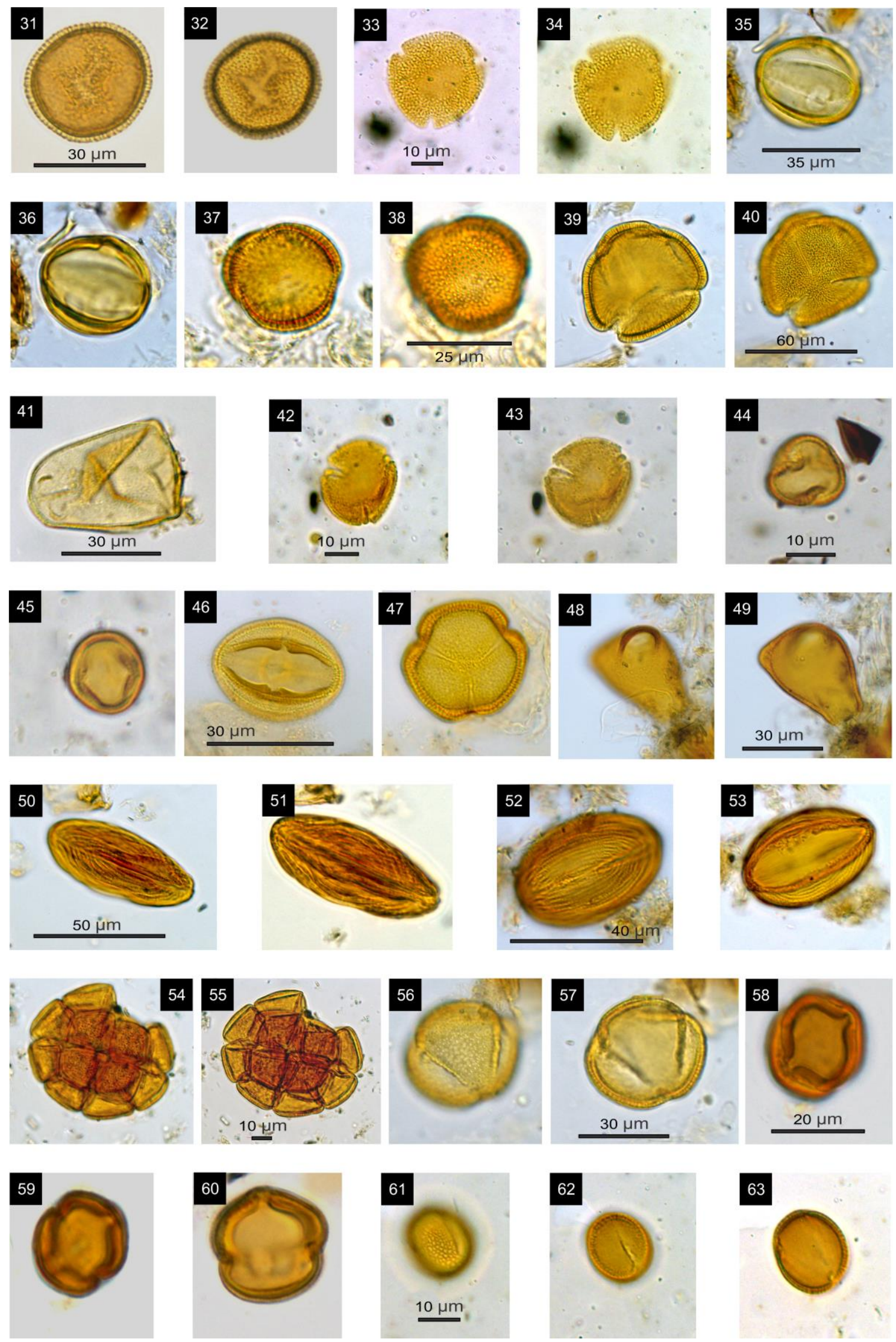

63 

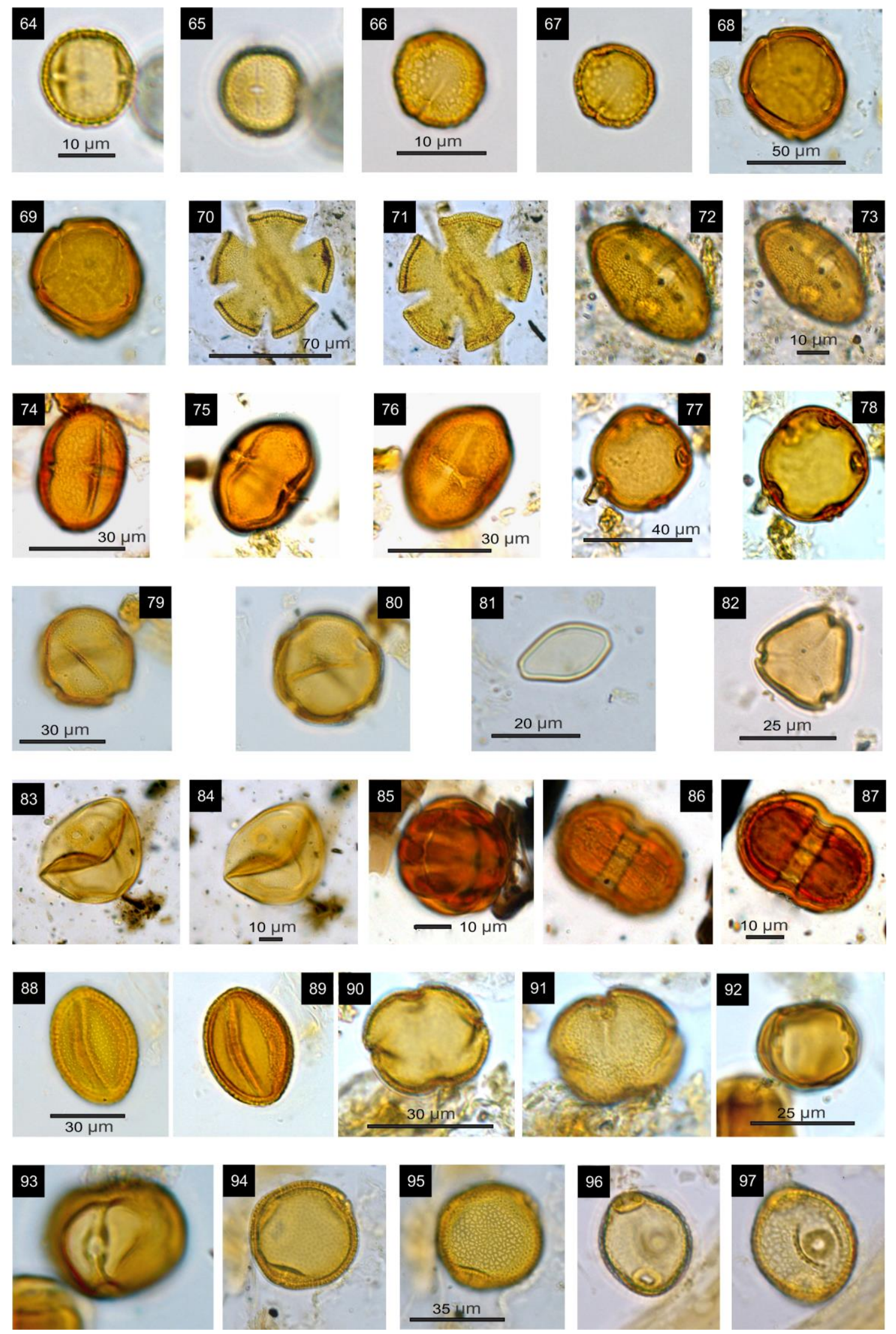

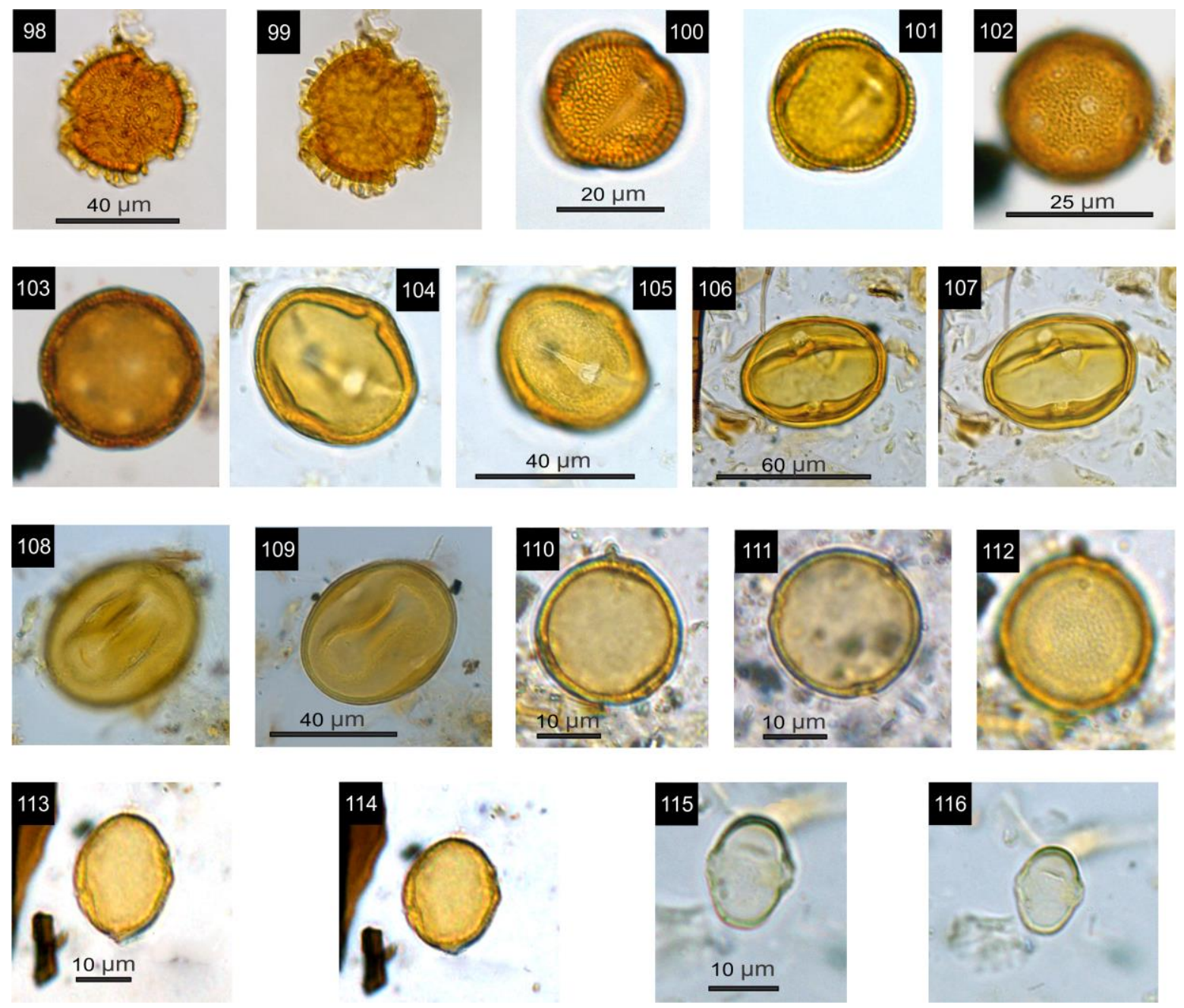
APPENDIX 2

Complete pollen Diagrams 


\section{Lago Amapá}

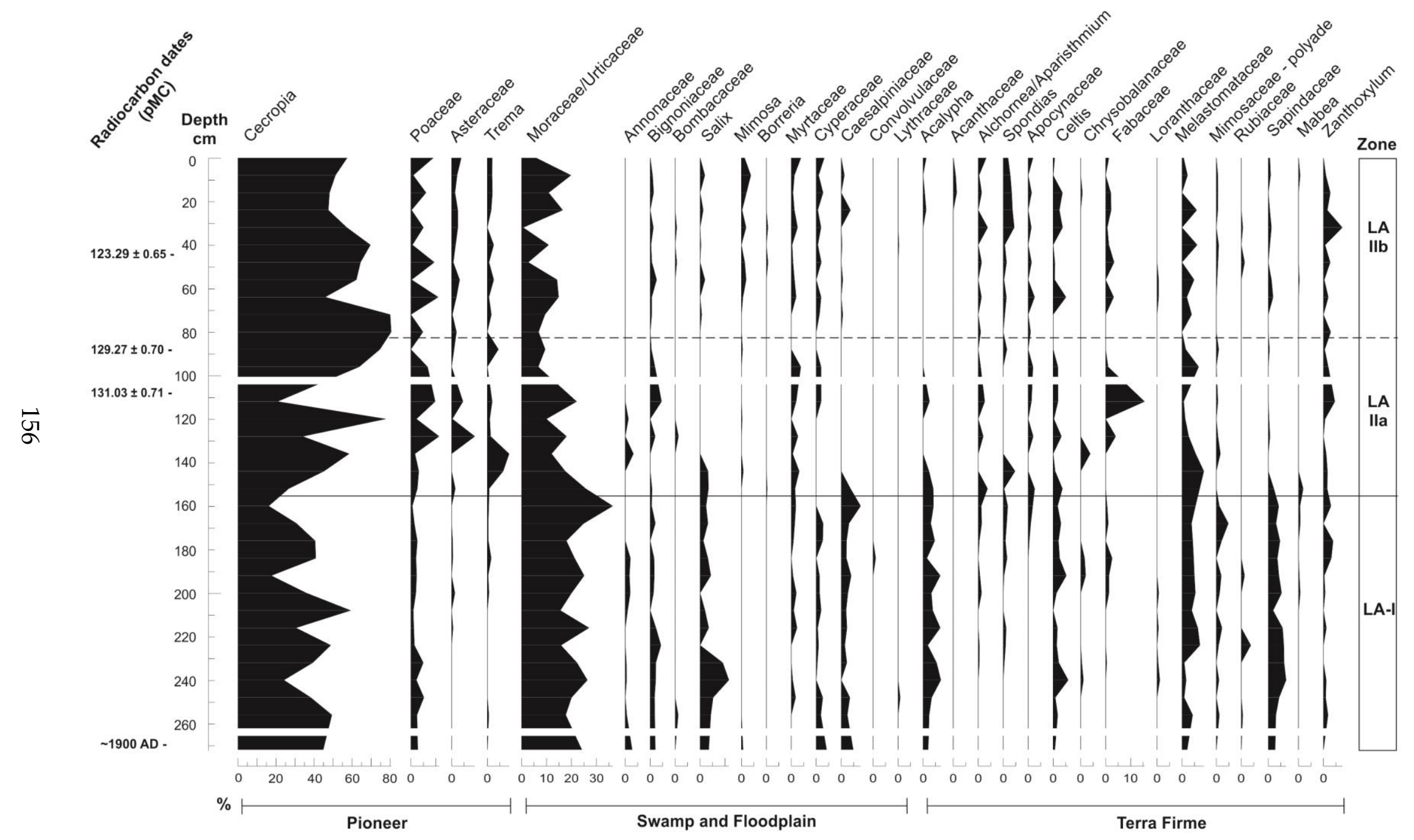




\section{Lago Amapá (continued)}

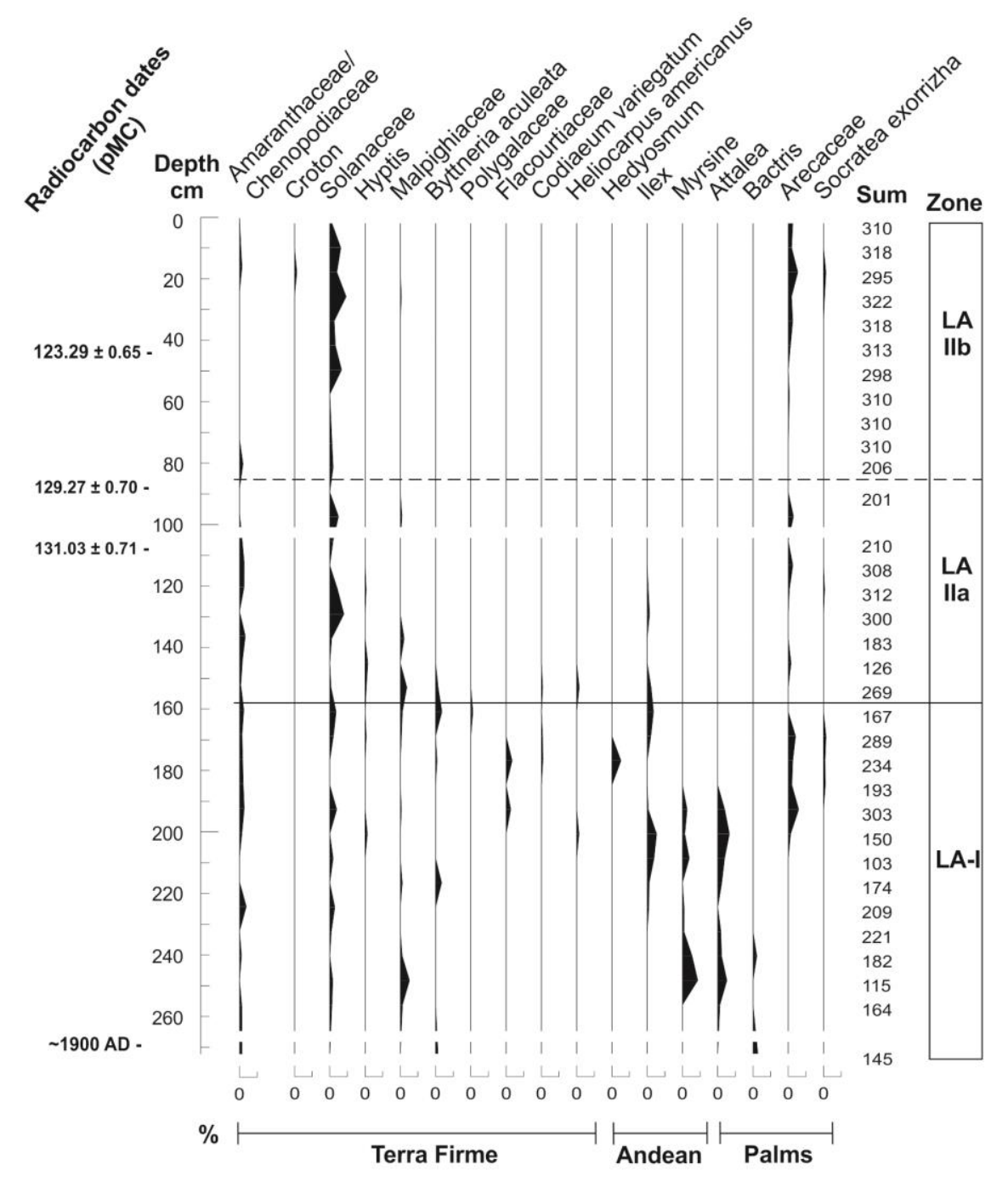

咅
少
产 


\section{Lago Amapá- (continued)}

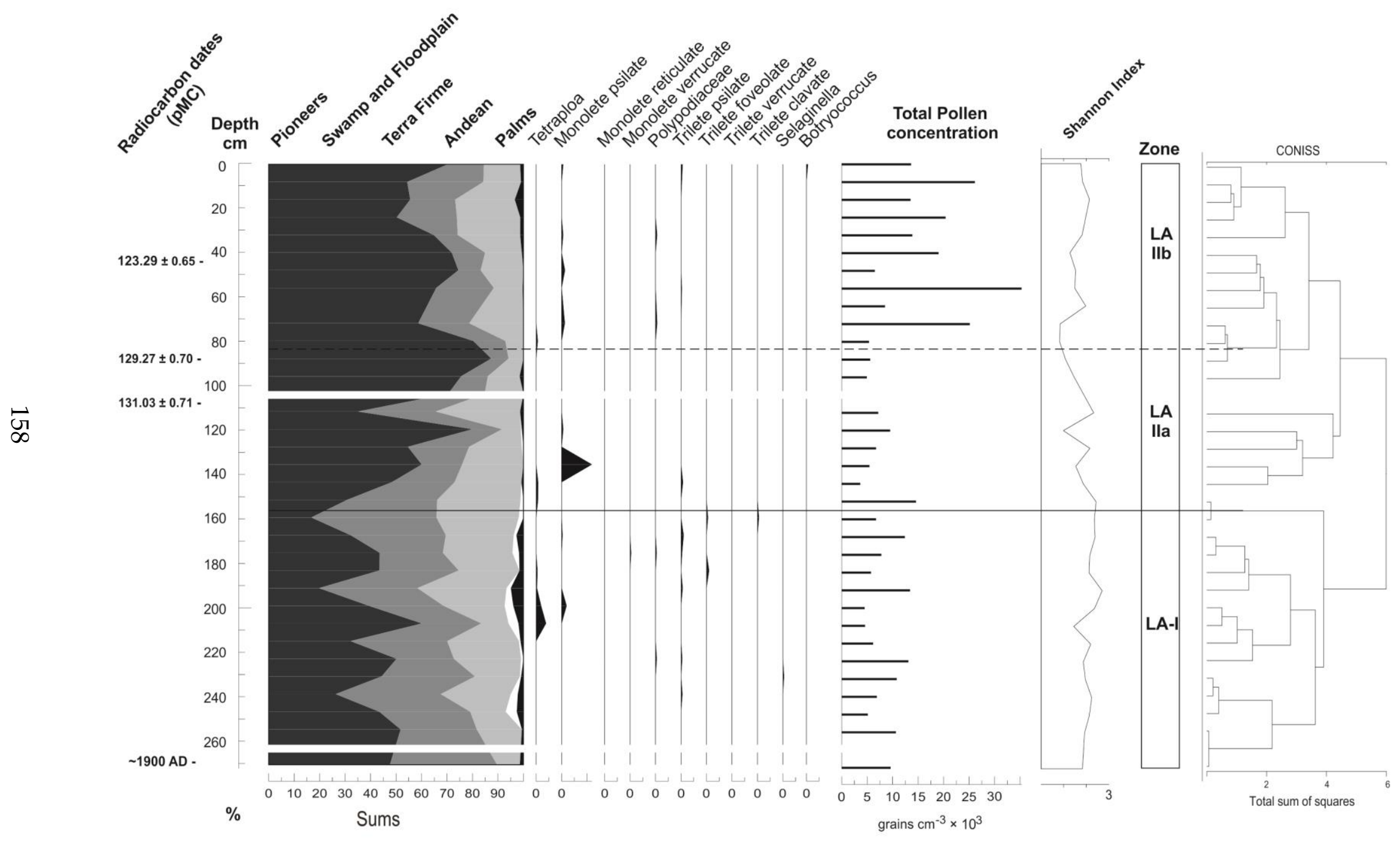




\section{Serra do Tepequém}

जั

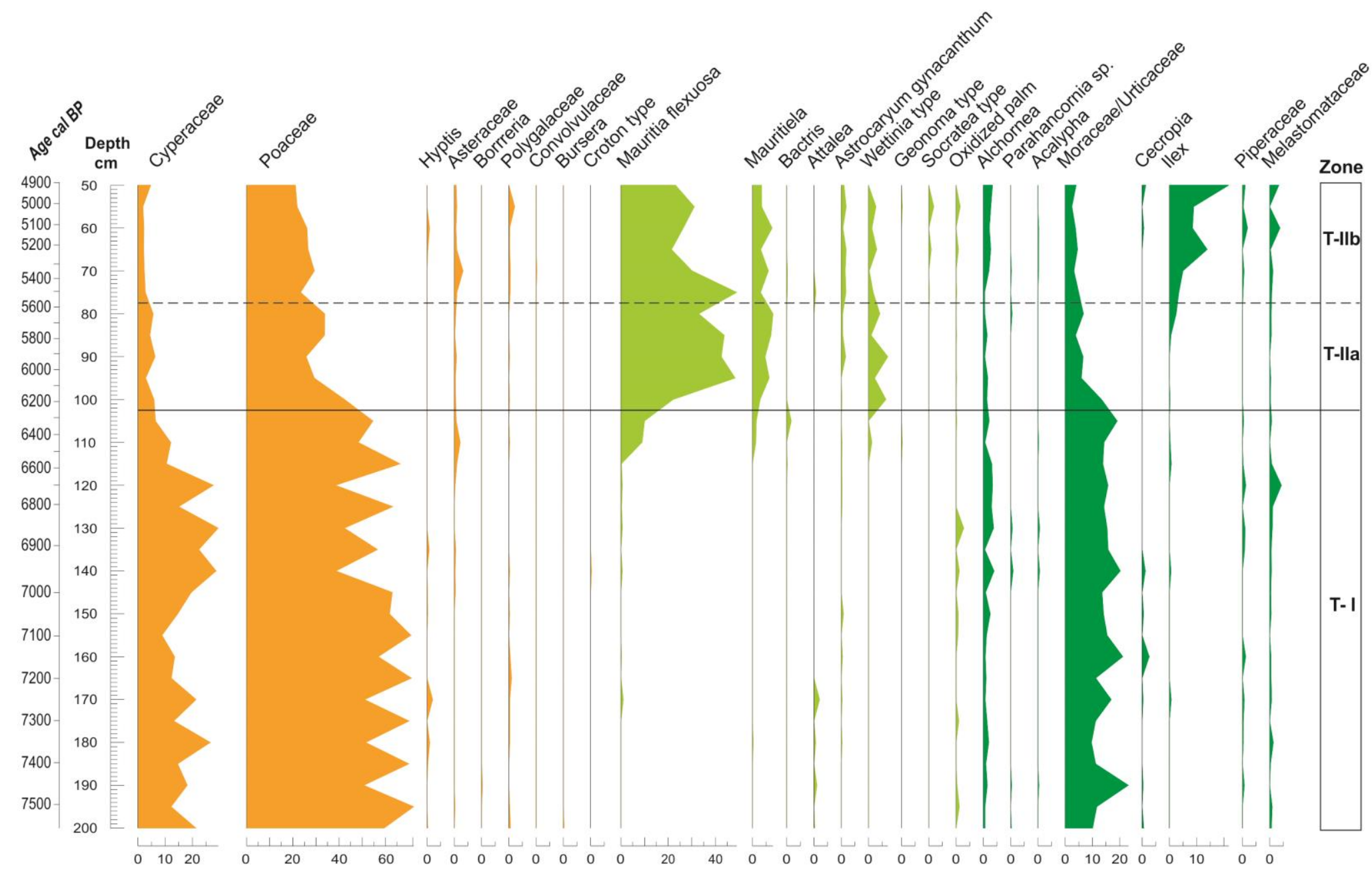
$\%$

Grassland

Palms

Forest 


\section{Serra do Tepequém (Continued)}

Бे

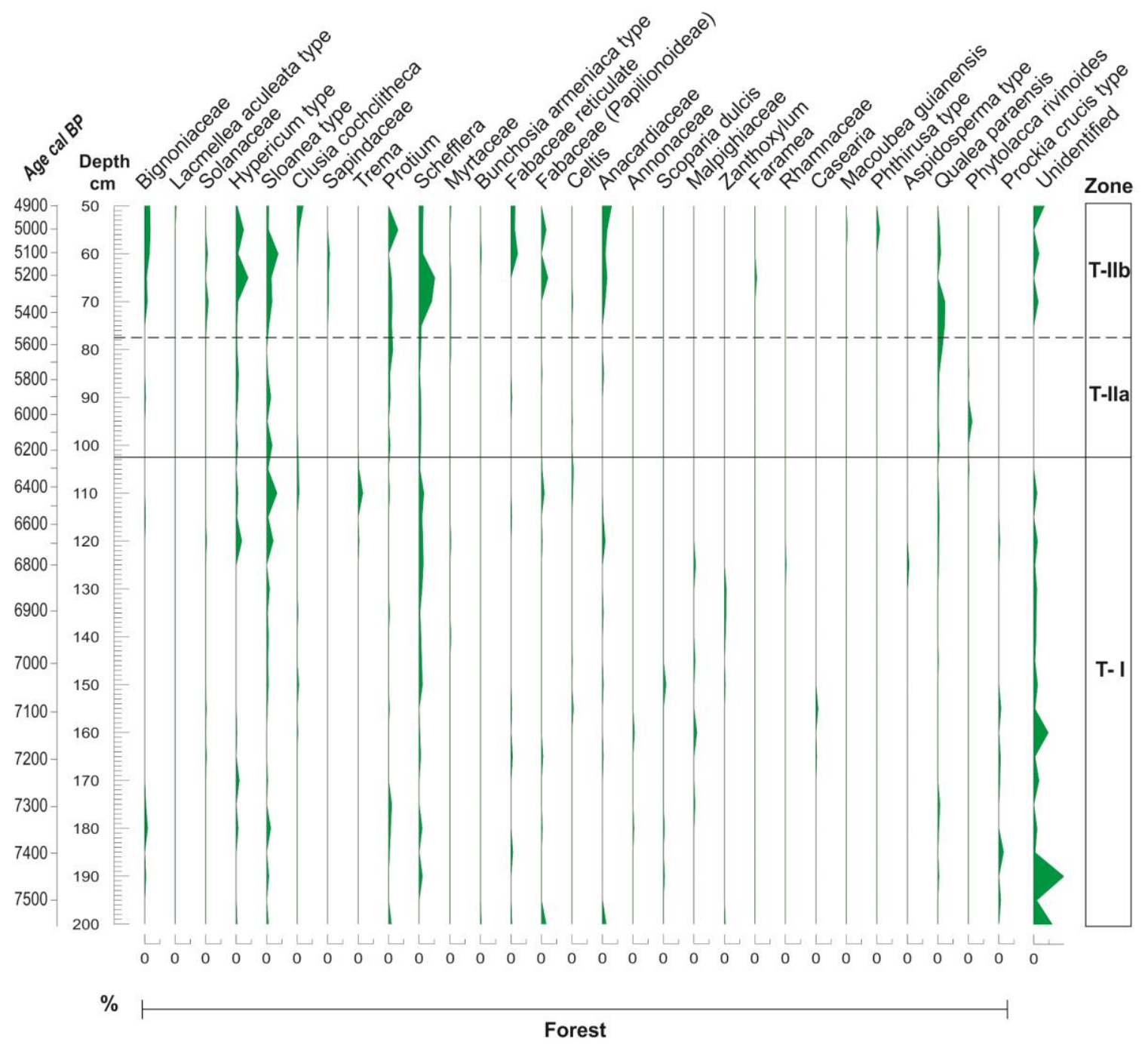




\section{Serra do Tepequém (Continued)}

$\vec{\sigma}$

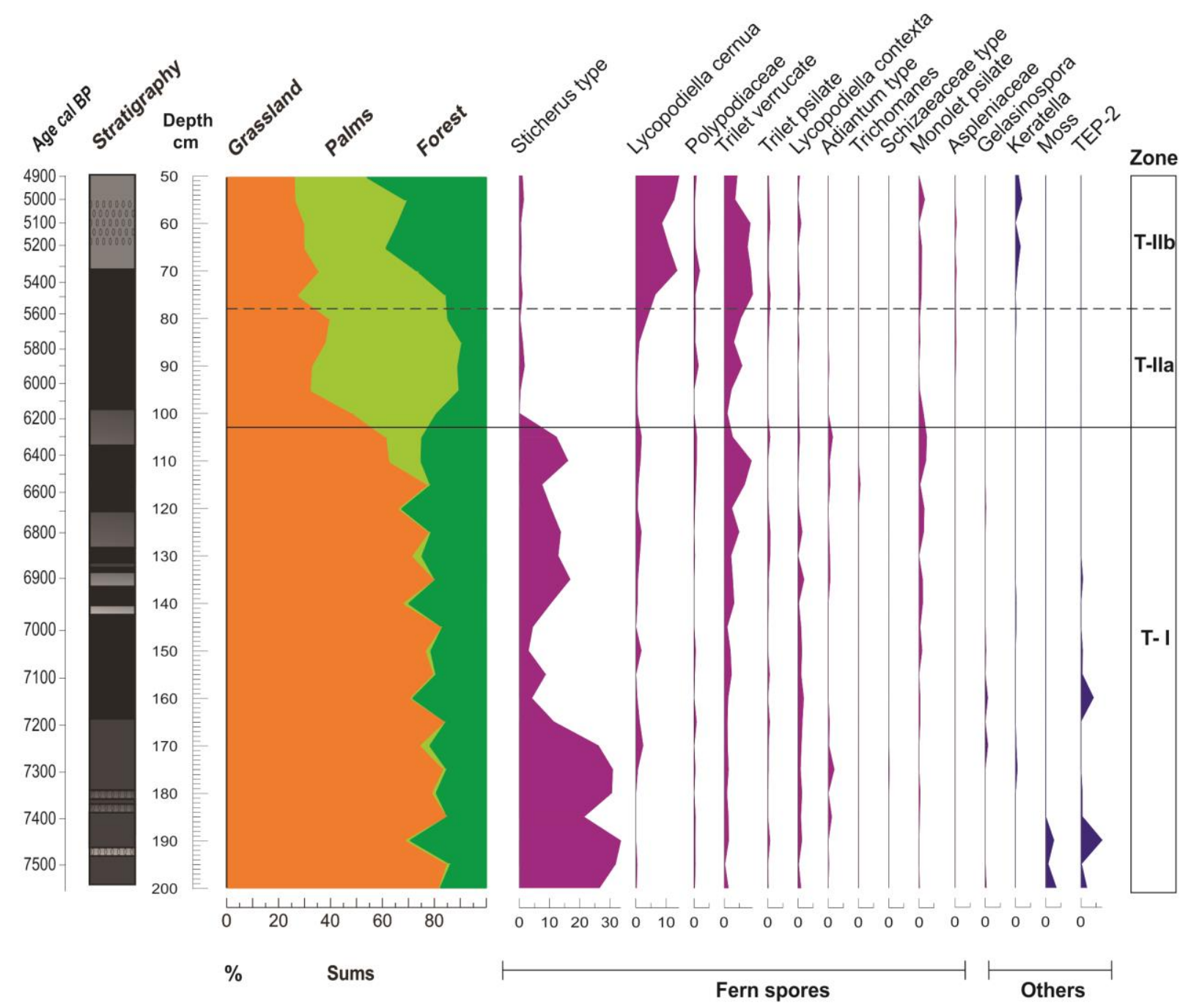




\section{Serra do Tepequém (Continued)}

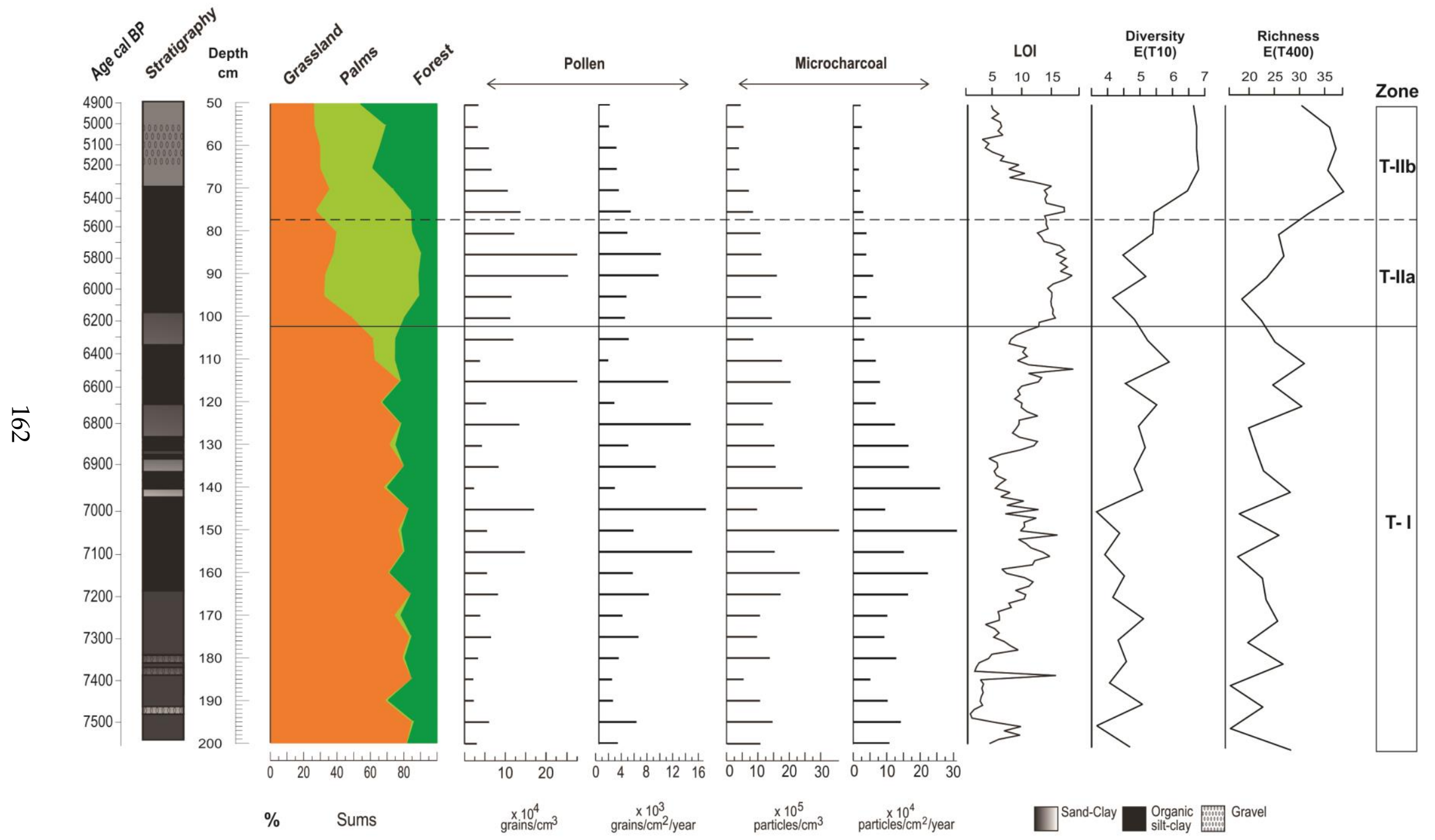




\section{Lake Acarabixi}

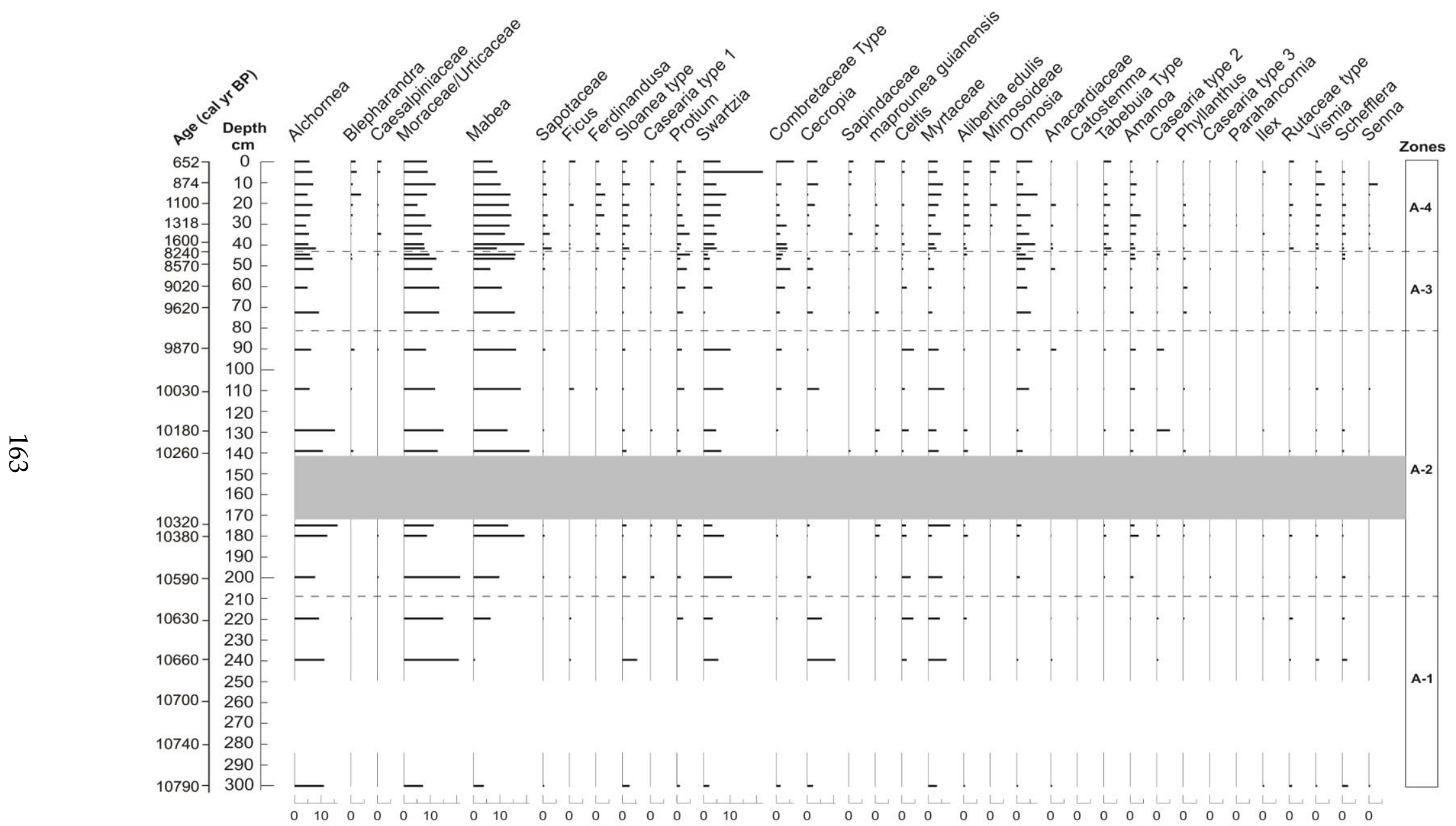

$$
\%
$$




\section{Lake Acarabixi (Continued)}

$\overrightarrow{5}$

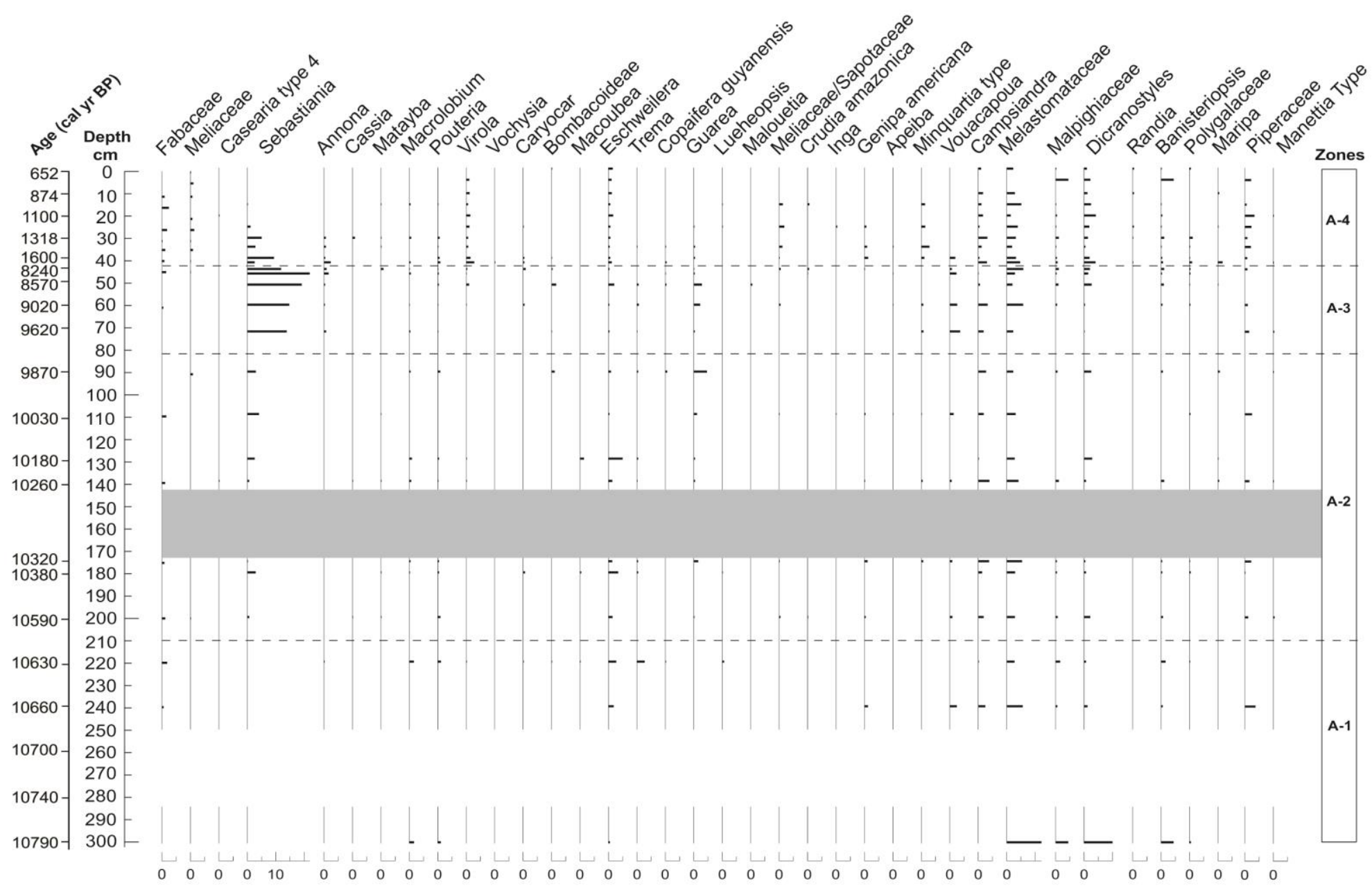
$\%$ 


\section{Lake Acarabixi (Continued)}

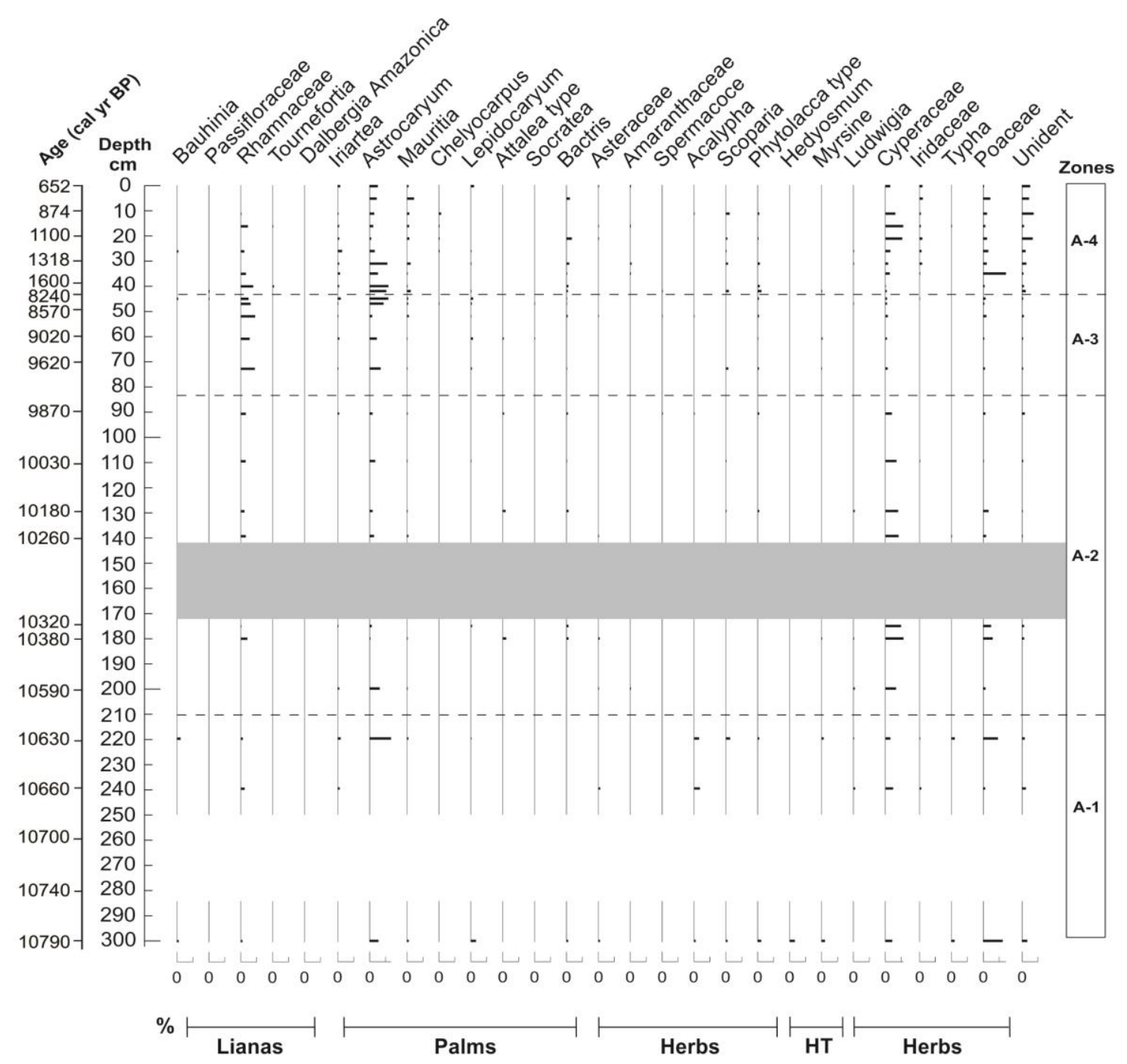




\section{Lake Acarabixi (Continued)}

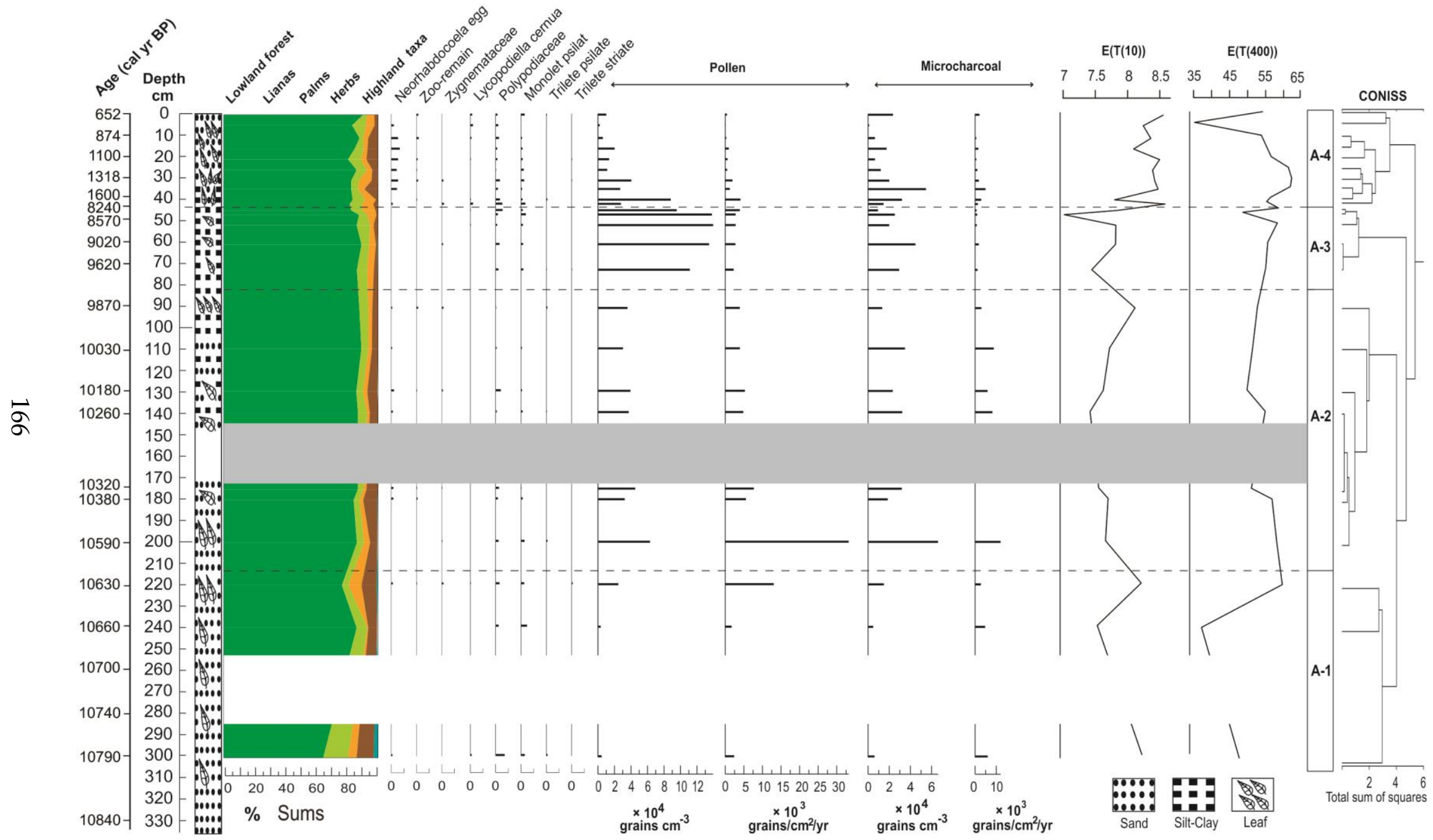




\section{APPENDIX 3}

\section{Acre River map from W. Chandless}

Source: Chandless, W., 1866. Notes on the river Aquiry, the principal affluent of the river Purûs. J. R. Geogr. Soc. Lond. 36, 119-128 
Complete map of Acre (Chandless, 1866)

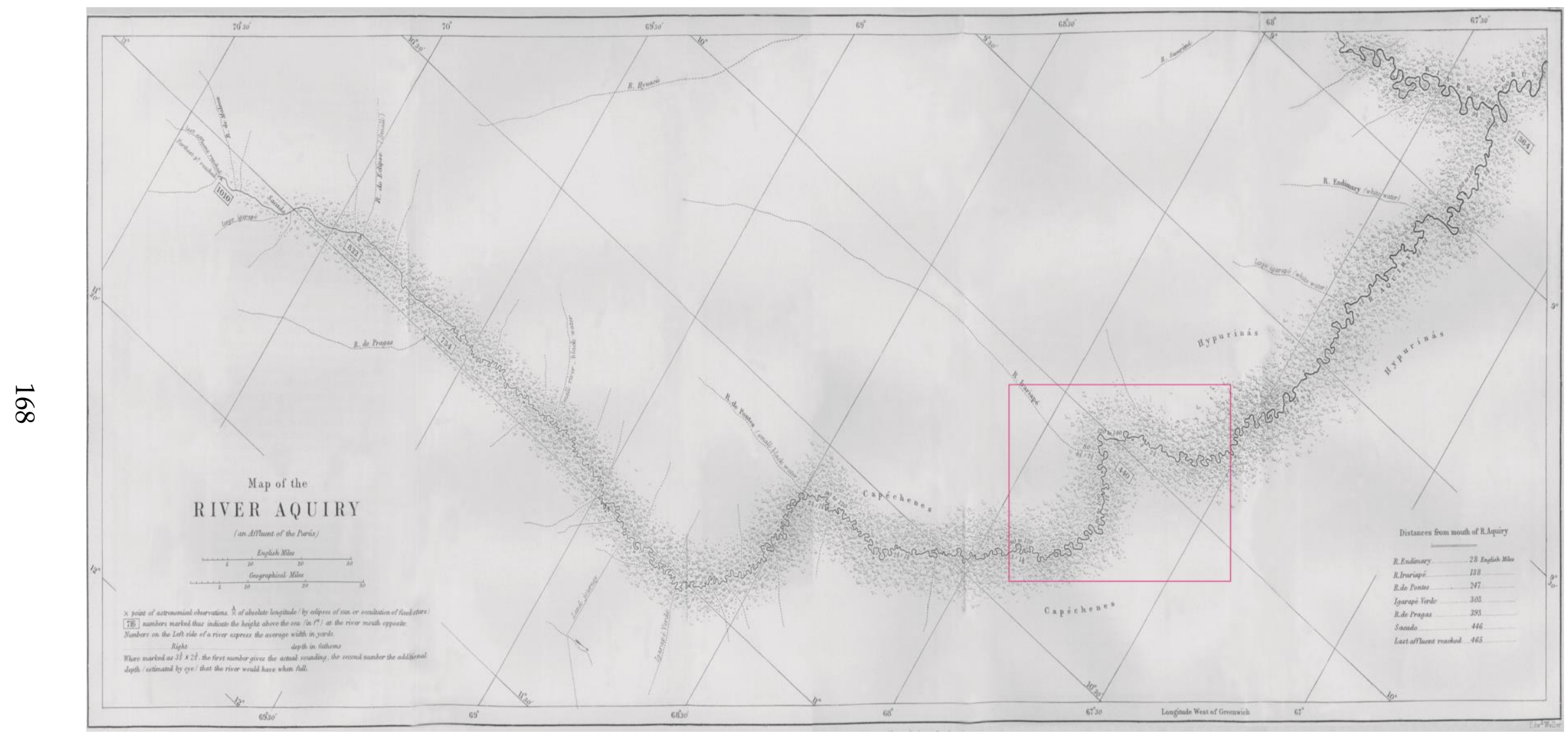


Map of Acre, Lago Amapá location (Chandless, 1866)

홍

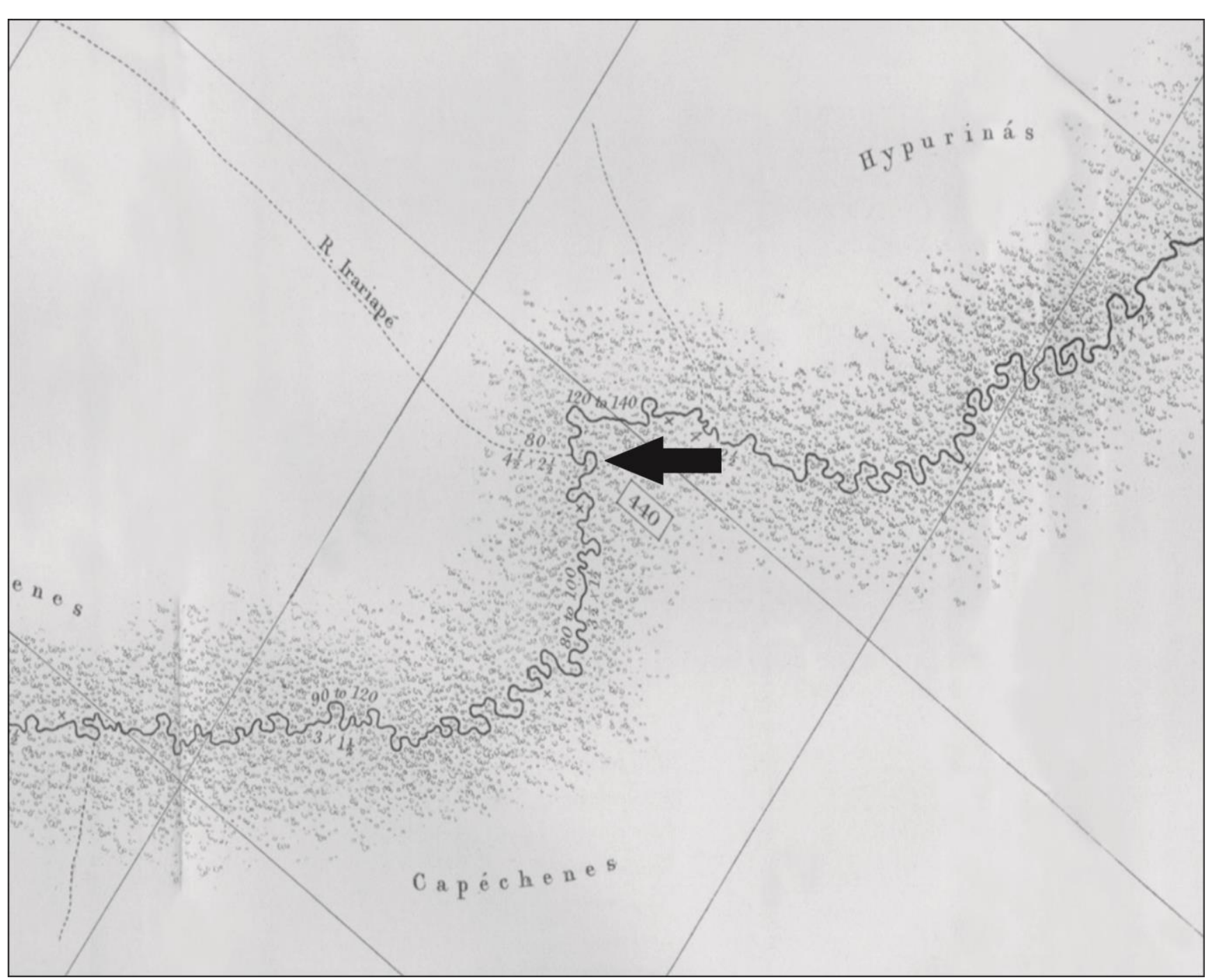


